Universidad de Lima

Facultad de Economía

Carrera de Contabilidad

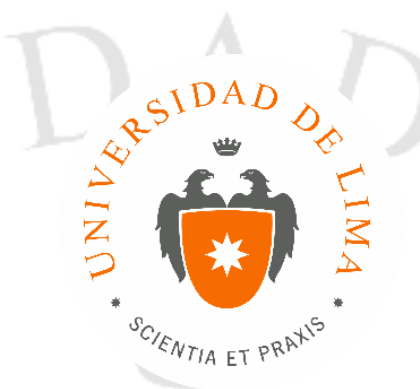

\title{
IMPLEMENTACIÓN DE AUDITORIA CON ENFOQUE BASADO EN RIESGOS EN EL PROCESO DE ATENCIÓN DE RECLAMOS DE UNA ENTIDAD FINANCIERA
}

Proyecto profesional teóricamente fundamentado para optar por el título profesional de Contador Público

\section{Alonso André Rivero Zanatta}

Código 20042013

\section{Asesor}

Oskar Harvey Segura Ojeda

$$
\text { Lima - Perú }
$$

Mayo del 2016 


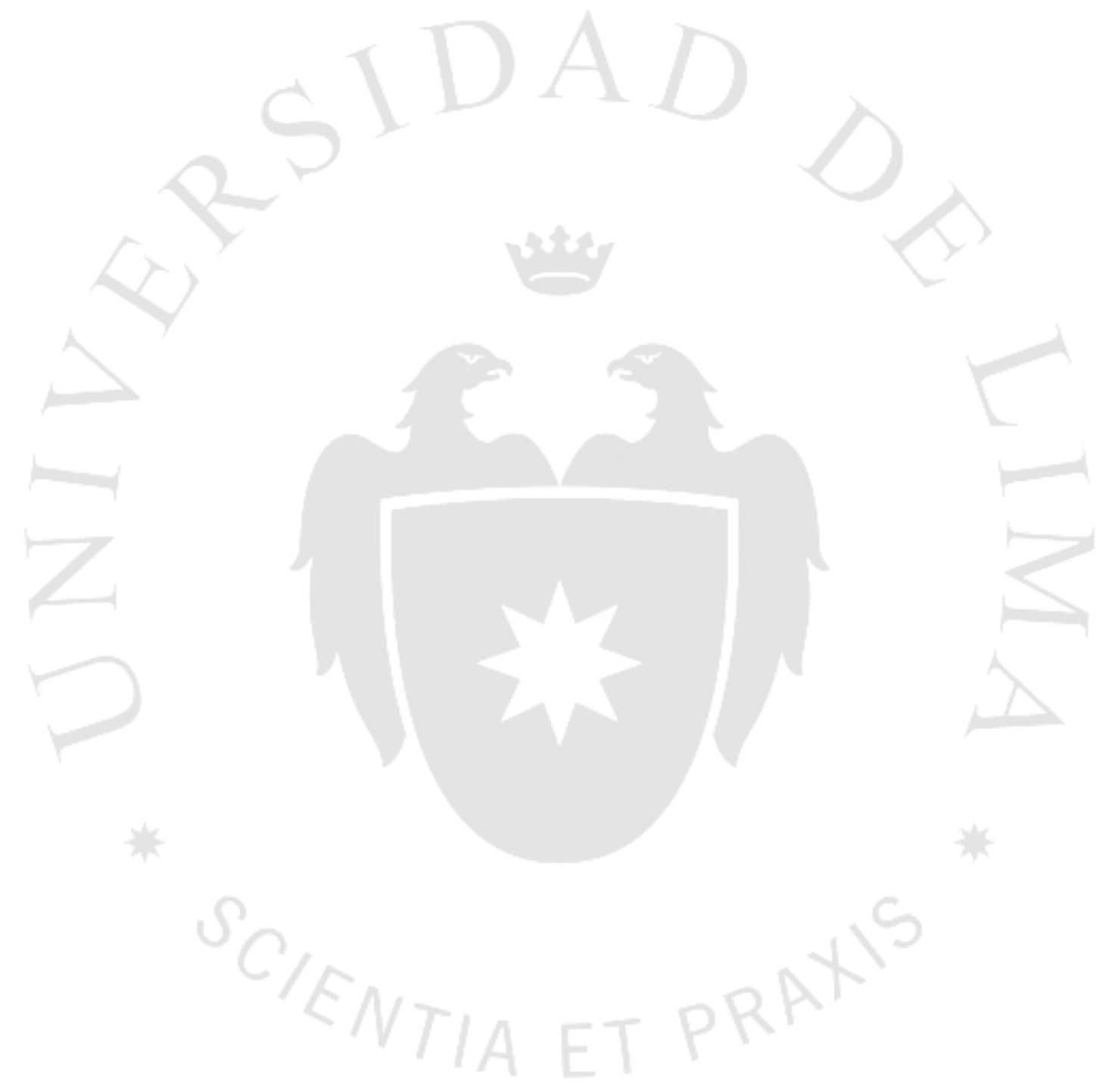




\section{IMPLEMENTACIÓN DE AUDITORIA CON ENFOQUE BASADO EN RIESGOS EN EL PROCESO DE ATENCIÓN DE RECLAMOS DE UNA ENTIDAD FINANCIERA}




\section{TABLA DE CONTENIDO}

INTRODUCCIÓN ....................................................................................................9

CAPÍTULO 1: PLANTEAMIENTO DEL PROBLEMA E HIPOTESIS...........12

1.1 El problema.............................................................. 12

1.2 Título del proyecto profesional ........................................ 13

$1.3 \quad$ Formulación del problema ................................................... 13

1.4 Causas del problema .................................................. 14

1.5 Consecuencias del problema ............................................. 15

CAPÍTULO 2: PROYECTO PROFESIONAL ......................................................17

2.1 Justificación del proyecto profesional ................................ 17

2.2 Delimitación del proyecto profesional ................................... 17

2.3 Objetivos del proyecto profesional ........................................ 18

2.3.1 Objetivo general ..................................................... 18

2.3.2 Objetivos específicos ................................................. 18

2.4 Hipótesis y variables.......................................................... 18

2.4.1 Hipótesis General ..................................................... 18

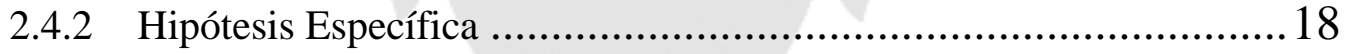

2.5 Definición de unidades de observación ..................................... 19

2.5.1 Variables Independientes ............................................... 19

2.5.2 Variables dependientes............................................... 19

CAPÍTULO 3: METODOLOGÍA DEL PROYECTO PROFESIONAL............20

3.1. Población y muestra ......................................................20

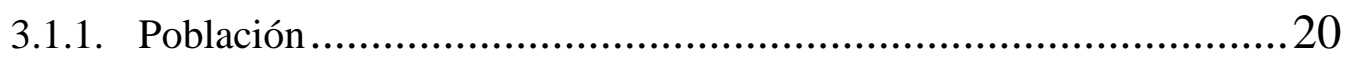

3.1.2. Muestra .......................................................................... 20

3.2. Técnicas ......................................................... 21

3.2.1. Recolección de información..............................................21

3.2.2. Diseño metodológico del proyecto .................................... 21 
3.3. Presentación de resultados ................................................. 22

CAPÍTULO 4: MARCO TEÓRICO....................................................................23

4.1 Base regulatoria .............................................................223

4.1.1 Normas aplicables a la ejecución de la función de auditoría interna...23

4.1.2 Normas aplicables al proceso de atención de reclamos ..................24

4.2 Auditoría interna .............................................................25

4.2.1 Definición ................................................................ 25

4.2.2 Objetivo..................................................................... 25

4.2.3 Importancia .................................................................. 25

4.2.4 Metodología ............................................................... 26

4.3 Marco para la práctica de auditoría Interna ................................32

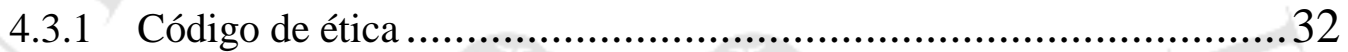

4.3.2 Normas internacionales de auditoría interna ............................33

4.4 Marco de control interno basado en gestión de riesgos de la empresa 36

4.4.1 Definición de ERM (Enterprise Risk Management) ......................36

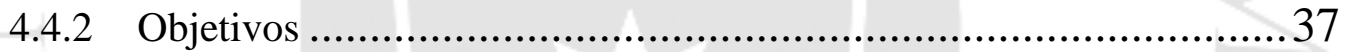

4.4.3 Componentes............................................................. 37

4.5 Evaluación del sistema de gestión de riesgos ..............................4 41

4.5.1 Introducción ..............................................................41

4.5.2 Auditoría interna en la gestión de riesgos para toda la empresa .......43

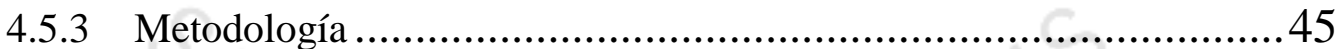

4.5.4 Identificación de Riesgos..................................................46

4.5.5 Elaboración de una Matriz de Riesgos ....................................4 46

4.5.6 Clasificación de las procesos conforme a los riesgos potenciales ......47

4.5.7 Desglose de las operaciones por subprocesos o actividades............47

4.5.8 Determinar la probabilidad e impacto bajo el criterio de auditoría.....47

4.5.9 Identificar actividades de control en respuesta a los riesgos ...........47

CAPÍTULO 5: ANÁLISIS Y PRESENTACIÓN DE RESULTADOS................49

$5.1 \quad$ Generalidades 
5.1.1 Información de la entidad financiera ...................................49

5.1.2 Misión y principios..........................................................50

5.1.3 Información del área auditada ...........................................50

5.1 .4 Auditoría Interna .........................................................52

5.1.5 Metodología de Auditoría Basada en Riesgos ............................53

5.2 Situaciones identificadas por la gerencia en proceso de mejora.........55

5.3 Plan anual de auditoría .......................................................55

5.3.1 Planeación administrativa ................................................56

5.3.2 Programación de fecha de la auditoría .....................................57

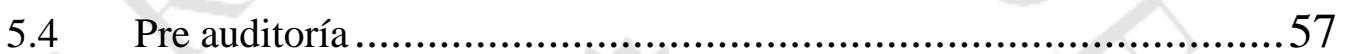

5.4.1 Identificación de los dueños del proceso ..................................58

5.4.2 Elaboración del requerimiento inicial de información ....................58

5.4.3 Elaboración del memorándum "Intención de auditoría".................58

5.4.4 Elaboración de la presentación de la reunión de inicio de auditoría ...59

5.5 Etapa de planeación .........................................................59

5.5.1 Objetivo General ......................................................60

5.5.2 Objetivos específicos ...................................................60

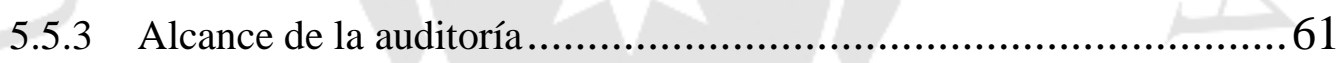

5.5.4 Entendimiento del proceso de atención de reclamos......................6 61

5.5.5 Identificación del universo de riesgos ...................................68

5.5.6 Identificación de Riesgos críticos........................................70

5.5.7 Elaboración del Flujograma de proceso ................................... 72

5.5.8 Identificación de controles clave asociados ...............................72

5.5.9 Pruebas de diseño de controles (PDC) ................................ 75

5.5.10 Resultado de la etapa de planeación ......................................86

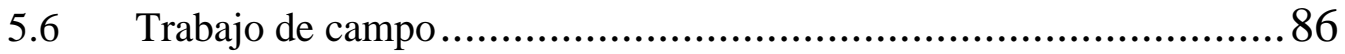

5.6.1 Programa de trabajo..................................................... 86

5.6.2 Selección de Muestras...........................................................8 86

5.6.3 Formato de Muestreo (FDM) ............................................. 90 
5.6.4 Pruebas de Eficacia de Controles (PEC)................................. 91

5.6.5 Desarrollo de Recomendaciones con valor agregado..................... 103

5.6.6 Raíz del problema e Impacto potencial .................................... 105

5.6.7 Categorización de la observación........................................... 106

5.6.8 Planes de acción planteados por el área de Atención de Reclamos ....107

5.7 Elaboración del reporte de auditoría interna............................... 107

5.8 Presentación de resultados al directorio .................................... 110

5.9 Documentación................................................................... 110

5.10 Seguimiento de implementación de mejoras en el área de atención de

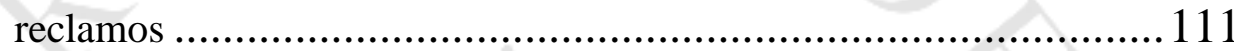

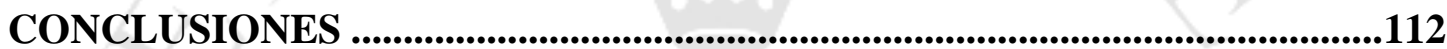

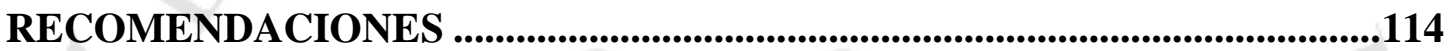

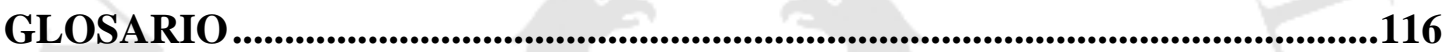

REFERENCIAS ...........................................................................................................120

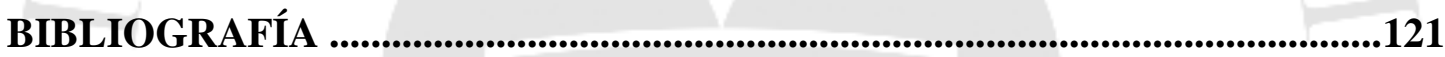

ANEXO N ${ }^{\circ} 1$ - MEMORÁNDUM REQUERIMIENTO.......................................123

ANEXO N N $^{\circ}$ - FLUJOGRAMA DEL PROCESO DE RECLAMOS................127

ANEXO N $\mathrm{N}^{\circ} 3$ - PRUEBAS DE DISEÑO DE CONTROLES ................................130

ANEXO N ${ }^{\circ} 4$ - FORMATO DE MUESTREO ..................................................144

ANEXO $\mathrm{N}^{\circ} 5$ - TABLA DE NIVELES DE OBSERVACIONES .......................151

ANEXO N $\mathrm{N}^{\circ} 6$ - REPORTE DE AUDITORÍA INTERNA.....................................154

ANEXO N $\mathrm{N}^{\circ} 7$ - DOCUMENTACIÓN ...................................................................168 


\section{INDICE DE TABLAS}

Tabla 5.1 - Staff responsable del proceso de auditoría..............................................56

Tabla 5.2 - Estimación de horas del equipo de auditoría ...........................................56

Tabla 5. 3 - Cronograma de actividades ...............................................................57

Tabla 5.4 - Estadística de reclamos recibidos por el Banco ...................................662

Tabla 5.5 - Matriz de Riesgos del proceso de atención de reclamos proporcionada por el negocio.......................................................................................667

Tabla 5.6- Universo de riesgos identificados por auditoría interna........................69

Tabla 5.7 - Matriz de riesgos calificados como críticos. ............................................ 71

Tabla 5.8 - Matriz de Riesgos y Controles Clave ........................................................73

Tabla 5.9 - Análisis de brechas de la circular SBS G 146-2009. ................................. 78

Tabla 5.10 - Formato de Prueba de Diseño de Controles...........................................8 84

Tabla 5.11 - Resumen del muestreo a realizarse ..........................................................88

Tabla 5.12 - Formato de Prueba de Eficacia de Controles (PEC) $\mathrm{N}^{\circ} 1.1$.................93

Tabla 5.13 - Formato de Prueba de Eficacia de Controles (PEC) $\mathrm{N}^{\circ} 3.1$................95

Tabla 5.14 - Formato de Prueba de Eficacia de Controles (PEC) $\mathrm{N}^{\circ} 6.1$..............101

Tabla 5.15 - Planes de acción planteados por el área de atención de reclamos....107 


\section{INDICE DE FIGURAS}

Figura 3.1 - Proceso de Auditoría Basada en Riesgos ..............................................222

Figura 5.1 - Organigrama área de atención al usuario .52 


\section{INTRODUCCIÓN}

El enfoque de la función de auditoría interna ha evolucionado en los últimos años, acompañado de cambios en el ambiente de negocios. Inicialmente la función de la unidad auditoría se enfocaba en actividades de aseguramiento del control interno, sin embargo, al presenciar cambios tecnológicos y en la manera de hacer negocios se ha optado por incorporar la evaluación de riesgos como un valor agregado para el cumplimiento de objetivos estratégicos.

En el Perú, el rol del auditor interno se encuentra determinado en base a la necesidad del negocio, políticas corporativas y regulación del país. Las entidades financieras, por ejemplo, son reguladas mediante la Superintendencia de Banca, Seguros y AFP (SBS), quién determina los lineamientos específicos para el cumplimiento de obligaciones con el estado y clientes financieros siendo la función del área de auditoría interna una obligación de acuerdo a lo estipulado en la resolución SBS $\mathrm{N}^{\circ} 37-2008$.

Partiendo de la obligación de contar con actividades de aseguramiento independientes dentro de la organización, se delimitan las responsabilidades del auditor interno en el reglamento de auditoría dictaminado por la SBS mediante resolución $\mathrm{N}^{\circ} 11699-2008$.

El artículo $4^{\circ}$ de dicha resolución establece lo siguiente:

"La Auditoría Interna es una actividad independiente y objetiva de aseguramiento y consulta, concebida para agregar valor y mejorar las operaciones de las empresas, al ayudarlas a cumplir sus objetivos aportando un enfoque sistemático y disciplinado en la evaluación y mejora de la eficacia de la gestión de riesgos y del gobierno corporativo."

Por otro lado, según el artículo $9^{\circ}$ la función del auditor se estandariza mediante la aplicación de las normas internacionales para el ejercicio profesional de la auditoría 
interna emitidas por el instituto de auditores internos (IAI) las cuales determinan normas sobre atributos y desempeño. Por otro lado, cada entidad financiera dependiendo de su línea de negocios deberá cumplir con actividades específicas establecidas en el mencionado reglamento.

Hasta este punto, podríamos concluir preliminarmente que el ejercicio profesional de la auditoría interna se desarrolla en virtud de las premisas del cumplimiento regulatorio y estándares internacionales. Sin embargo, el enfoque de trabajo se estaría limitando a efectuar auditorías de cumplimiento evaluando sólo los riesgos de carácter regulatorio dejando de lado determinar si los procesos de gestión de riesgos son eficaces de acuerdo a las siguientes afirmaciones:

- Los objetivos de la organización apoyan a la misión de la organización y están alineados con la misma.

- Los riesgos significativos están identificados y evaluados.

- Se han seleccionado respuestas apropiadas al riesgo que alinean los riesgos con la aceptación de los mismos por parte de la organización.

- Se capta información sobre riesgos relevantes, permitiendo al personal, la dirección y el consejo cumplir con sus responsabilidades, y se comunica dicha información oportunamente a través de la organización. (IAIA, Normas de Desempeño, 2012).

Por otro lado, las mejores prácticas del Marco Internacional para la Práctica Profesional de la Auditoría Interna dan énfasis a la necesidad de elaborar un plan anual de auditoría basada en riesgos. (IAI, Consejo para la Práctica IIA 2010-1 y el IIA 20102, 2012).

Ante la necesidad de establecer una adecuada evaluación de la gestión de riesgos para una mejor comprensión de los procesos operativos, financieros y comerciales en el negocio, una metodología para el ejercicio de la función de auditoría interna con enfoque basado en riesgos permitirá a la compañía el logro de los objetivos planteados. Dicha metodología se alinea a los estándares establecidos en las normas internacionales para el ejercicio profesional de la auditoría interna emitidos por el instituto de auditores internos (IAI). 
Es necesario para la implementación de esta nueva metodología una autorización del regulador según lo establecido en el artículo $10^{\circ}$ resolución SBS $\mathrm{N}^{\circ} 11699-2008$ debido a que las actividades programadas (14 en el caso de bancos) deben desarrollarse en un año calendario. Sin embargo, el plan establecido de auditoría basada en riesgos es a 4 años.

Debido a la amplitud de las actividades a realizarse ilustraremos la implementación de la nueva metodología basada en riesgos en el proceso de atención de reclamos de un banco, dichos procedimientos serán explicados a detalle en el desarrollo de este proyecto.

Por motivos de confidencialidad en los datos expuestos en el presente proyecto, se hará referencia a la entidad financiera como "El banco", en dónde la metodología de auditoría basada en riesgos fue diseñada y elaborada por la casa matriz. 


\section{CAPÍTULO 1: PLANTEAMIENTO DEL PROBLEMA E}

\section{HIPOTESIS}

\subsection{El problema}

El banco, es una entidad financiera con presencia en el país desde el año 1920. Desde el inicio de sus operaciones, se han presentado cambios significativos en el sector y en el marco regulatorio acompañados de nuevas tendencias globales en el ambiente de negocio. El banco, cuenta con una casa matriz ubicada en estados unidos la cual establece las políticas corporativas y lineamientos generales en las operaciones, reportes, estructura organizacional, cultura, gobierno entre las más importantes.

A fines del año 2013, se ha identificado la necesidad de reforzar la gestión integral de riesgos a los cuales se encuentran expuestos sus filiales alrededor del mundo, lo que conlleva a modificar el enfoque actual de la función de auditoría interna.

Las Auditorías que se realizan anualmente derivan en recomendaciones que se aplican al sistema de control Interno con la finalidad de mejorar la eficiencia y efectividad de los procesos. Las medidas correctivas al estar orientadas al cumplimiento regulatorio pueden mitigar riesgos de sanción por parte del regulador, sin embargo no estarían contemplando generar un valor agregado a la organización en lo que respecta al cumplimiento de objetivos estratégicos.

El proceso de Auditoría toma como marco de referencia los procedimientos establecidos en la resolución SBS N 11699-2008 "Reglamento de auditoría interna", los cuales se ejecutan tomando en consideración los lineamientos establecidos en la norma y por lo general no considera otros riesgos que también afectan al sistema de control interno.

Es importante resaltar que la Auditoría basada en riesgos se enmarca dentro la denominada Auditoría de Gestión que tiene como fin el proporcionar una evaluación 
independiente sobre el desempeño de una entidad, programa o proyecto, orientada a mejorar la efectividad, eficiencia y economía en el uso de los recursos.

Esto se vincula con la evaluación del desempeño que implica comparar la ruta seguida por la entidad al conducir sus actividades con los objetivos, metas, políticas y normas establecidos por la legislación o por la propia entidad; y otros criterios razonables de evaluación.

Esto lleva el reto de adoptar las mejores prácticas utilizadas internacionalmente en el control interno y riesgos, lo que significó alinear el proceso de auditoría interna del Banco con los lineamientos establecidos en el planeamiento estratégico.

\subsection{Título del proyecto profesional}

Implementación de auditoria con enfoque basado en riesgos en el proceso de atención de reclamos de una entidad financiera.

\subsection{Formulación del problema}

El control interno es un proceso realizado por la administración y demás personal de la empresa, diseñado para proporcionar seguridad razonable en la búsqueda de cumplimiento de los objetivos.

Las políticas y procedimientos son actividades de control que permiten asegurar que se están realizando las acciones necesarias para el logro de los objetivos de la empresa; y el establecimiento de políticas servirá de base para crear los procedimientos que llevarán a cabo el cumplimiento de la misma.

El proceso de auditoría de cumplimiento se enfoca en evaluar los riesgos relacionados a identificar desviaciones en la aplicación de la regulación local, sin embargo no se brinda un servicio de aseguramiento con valor agregado al no considerar las expectativas de los principales grupos de interés de la organización: Los Stakeholders.

Actualmente existen expectativas cada vez mayores de los stakeholders y dónde quieren que actúe auditoría interna en el contexto de la gestión de riesgos, para aportar 
el máximo valor posible. Los principales equipos de auditoría interna se han alineado con estas expectativas crecientes de los stakeholders, ampliando el alcance de los riesgos que abarcan y comunicando claramente una información de mayor valor y profundidad, "subiendo el nivel" de forma que se fije un nuevo estándar para los equipos de auditoría interna de todos los sectores, ámbitos geográficos y tamaños de compañías. Los stakeholders y los responsables de auditoría interna han reconocido que, para que esta función sea eficaz a la hora de respaldar las medidas de gestión de riesgos de la organización, es necesario aumentar el estándar mínimo de desempeño. En un escenario de riesgos tan cambiante como el actual, la auditoría interna no puede conformarse con limitarse a reaccionar ante los acontecimientos; en su lugar, debe adoptar una mentalidad estratégica que tenga capacidad de respuesta ante los riesgos y que contribuya a ayudar a sus organizaciones a estar listas ante nuevas amenazas y oportunidades.

\subsection{Causas del problema}

En todos los sectores y territorios, los grupos de interés (inversores, proveedores, el regulador, etc.) de las compañías se interesan cada vez más por la gestión de riesgos y tratan de mejorar su capacidad para definir y comunicar con claridad la tolerancia al riesgo de su organización. Esto se ha traducido en destinar mayores recursos en mejorar el sistema de control interno y darle importancia a la gestión de riesgos.

Los riesgos están aumentando en las organizaciones y que el entorno cambia rápidamente a medida que surgen nuevos riesgos. Los retos asociados a los riesgos más tradicionales siguen evolucionando, y los stakeholders y los responsables de Auditoría varían su elección en referencia a los riesgos más importantes a los que se enfrentan sus organizaciones. Además de las preocupaciones derivadas de la incertidumbre económica, la existencia de un mayor número de requisitos regulatorios y los enormes vaivenes experimentados por los mercados financieros en los últimos cuatro años, seguimos viendo cómo las compañías continúan mencionando algunas de las áreas tradicionales de preocupación, como el fraude y la ética, las fusiones y adquisiciones, los proyectos de grandes dimensiones, la introducción de nuevos productos y la continuidad del negocio, entre sus cinco riesgos principales. 
La fuerte interrelación existente entre la economía real y los mercados financieros provoca que los riesgos surjan de manera inesperada y con unos impactos derivados de gran alcance en lo relativo a la reputación, e incluso a la supervivencia del negocio.

Las auditorías enfocadas enteramente al cumplimiento no aportan un valor agregado a la organización al no contemplar en el desarrollo de su función permitir a la organización a trabajar de manera eficiente y eficaz a fin de lograr sus objetivos.

El equipo corporativo del banco ha determinado cubrir las expectativas de los stakeholders a través del desarrollo de una actividad de aseguramiento que permita mitigar los principales riesgos a los que se encuentra expuesto el negocio para así poder alcanzar los objetivos de la organización.

\subsection{Consecuencias del problema}

Como bien se mencionó en la sección anterior, la función de auditoría enfocada en cumplimiento del marco regulatorio establece una brecha significativa en la mejora de la eficiencia y efectividad de los procesos en la organización debido a que estaría limitando su alcance a cumplir únicamente con los lineamientos establecidos por el regulador.

Al no considerar una adecuada evaluación de los riesgos a los que se encuentra expuesta la organización ni las expectativas de los stakeholders, la función de auditoría interna puede recibir una percepción negativa de su rol en la compañía y verse comprometido el desenvolvimiento de los profesionales así como limitar su desarrollo en el mercado financiero del Perú.

Se han identificado posibles consecuencias a niveles de organización, unidades de negocio y de la función de auditoría interna las cuales se describen a continuación:

\section{- Nivel Organización:}

- Incapacidad de lograr los objetivos establecidos por los directores.

- No considerar nuevos riesgos a los que se encuentra expuesta la organización.

- Impacto en la reputación del banco. 
- Eventos de fraude

- Sobre costos innecesarios.

- Nivel de unidades de negocio

- Incapacidad de lograr los objetivos del área establecidos por la gerencia

- Ineficiencia en la ejecución de actividades en los sub procesos

- Eventos de fraude

- Incumplimiento de políticas internas de la compañía

- Uso ineficaz de recursos

- Nivel de la función de auditoría interna

- Impacto en la reputación del equipo de auditoría interna

- Estancamiento en el desarrollo profesional del equipo

- Percepción de obligatoriedad en la contratación de auditores internos. 


\section{CAPÍTULO 2: PROYECTO PROFESIONAL}

\subsection{Justificación del proyecto profesional}

Las mejores prácticas del Marco Internacional para la Práctica Profesional de la Auditoría Interna dan énfasis a la necesidad de elaborar un plan anual de auditoría basada en riesgos. (IAI, Consejo para la Práctica IIA 2010-1 y el IIA 2010-2, 2012).

Ante la necesidad de establecer una adecuada evaluación de la gestión de riesgos para una mejor comprensión de los procesos operativos, financieros y comerciales en el negocio, la casa matriz ha establecido una nueva metodología para el ejercicio de la función de auditoría interna para integrar la evaluación de la gestión integral de riesgos. Dicha metodología se alinea a los estándares establecidos en las normas internacionales para el ejercicio profesional de la auditoría interna emitidos por el instituto de auditores internos (IAI).

Es necesario para la implementación de esta nueva metodología un autorización del regulador según lo establecido en el artículo $10^{\circ}$ resolución SBS N¹1699-2008 debido a que las actividades programadas (14 en el caso de bancos) deben desarrollarse en un año calendario. Sin embargo, el plan establecido de auditoría basada en riesgos es a 4 años.

\subsection{Delimitación del proyecto profesional}

\section{Alcance}

El alcance del proyecto profesional refiere a la ejecución del proceso de auditoría basada en riesgos en el proceso de atención de reclamos y se desarrolla de acuerdo a la metodología establecida por la casa matriz la cual consta de las siguientes etapas:

- Pre auditoría

- Planeación

- Trabajo de campo 
- Reporte

\subsection{Objetivos del proyecto profesional}

\subsubsection{Objetivo general}

Demostrar que la ejecución de actividades de auditoria interna con un enfoque basado en gestión de riesgos permite evaluar sistemáticamente el funcionamiento del proceso de atención de reclamos.

\subsubsection{Objetivos específicos}

- Desarrollar la metodología de auditoría basada en riesgos establecida por la casa matriz en la evaluación del proceso de atención de reclamos.

- Contribuir al logro de objetivos mediante la evaluación de la gestión de riesgos a los que se encuentra expuesta el área de reclamos.

- Desarrollar recomendaciones que añadan valor a la organización.

- Evaluar el cumplimiento de la normativa interna y regulatoria aplicable al proceso de reclamos.

\subsection{Hipótesis y variables}

\subsubsection{Hipótesis General}

La implementación de auditoria con enfoque basado en riesgos en una entidad financiera contribuirá a obtener un mayor nivel de aseguramiento de que los procesos de gestión de riesgos funcionan eficazmente.

\subsubsection{Hipótesis Específica}

Si se desarrolla una auditoria con enfoque basado en riesgos, se podrá evaluar de manera sistemática el proceso de gestión de riesgos de la compañía, con lo que se contribuirá a asegurar al logro de objetivos de la organización.

Así mismo, se podrá alinear el ejercicio de la función de auditoría con las expectativas de los grupos de interés (Stakeholders) con lo que el resultado del trabajo añadirá valor a la organización. 


\subsection{Definición de unidades de observación}

\subsubsection{Variables Independientes}

- Nuevas Amenazas y oportunidades en el ambiente de negocio.

- Controles sin riesgos asociados.

- Enfoque de procesos en base a Cumplimiento regulatorio.

- Falta de consideración de las expectativas de los stakeholders.

\subsubsection{Variables dependientes}

- Logro de Objetivos.

- Planificación de auditoría con enfoque en riesgos.

- Evaluación del nivel de madurez del sistema de gestión integral de riesgos.

- Elaboración de recomendaciones con valor añadido al directorio. 


\section{CAPÍTULO 3: METODOLOGÍA DEL PROYECTO PROFESIONAL}

\subsection{Población y muestra}

La población y muestra del estudio para el presente proyecto fue la siguiente:

\subsubsection{Población}

El universo auditable suele estar conformado por procesos, programas, proyectos o áreas consideradas estratégicas en la organización. Al mismo tiempo, se debe tomar en cuenta la vinculación de la materia auditable con las actividades estratégicas vigentes de la entidad

Priorizando el universo auditable para realizar auditorías se efectúa en base a una metodología que ayude a tomar en cuentas aspectos del tamaño, tiempo (antigüedad de la última auditoría) y apreciaciones sobre el nivel de riesgo involucrado. La cantidad de auditorías a realizar están limitadas por la capacidad operativa de auditores y el tiempo estimado de cada una de ellas para su realización. (Juan Alberto Villanueva Chang, Plan Anual de Auditoría Interna Basado en Riesgos: Guía práctica para su implementación)

La población, se determinó en base a las actividades contempladas en el plan de auditoría basada en riesgos, aprobado por la SBS, y esté conformada por 39 procesos determinados en base a su nivel de criticidad.

\subsubsection{Muestra}

Como muestra se toma el proceso de atención de reclamos el cual fue una de las auditorías en las que participó el autor como consultor externo bajo la modalidad de cosourcing, es decir, se tercerizó parte del área de auditoría interna, sin embargo, se reportó al Gerente de auditoría interna del Banco. 


\subsection{Técnicas}

\subsubsection{Recolección de información}

La información fue recolectada directamente del Banco mediante relevamiento y entendimiento de información acerca del proceso de atención de reclamos y de la metodología de Auditoría Basada en Riesgos establecida por la casa matriz. Esta última información se considera, confiable y vigente ya que se fundamenta en la Norma IIA sobre Desempeño 2010 - Planificación, el Consejo para la Práctica IIA 2010-1 y el IIA 2010-2 para la cual el auditor debe tener pleno conocimiento del marco ERM el cual será explicado en el capítulo 4.

Los datos referentes al proceso de atención de reclamos serán extraídos mediante entrevistas con el personal del área de atención al cliente y las evidencias que los mismos proporcionen.

\subsubsection{Diseño metodológico del proyecto}

Para la realización del presente proyecto se siguieron las siguientes acciones:

- Recolectar material de capacitación y formatos requeridos por la metodología ABR.

- Seleccionar el proceso a evaluar

- Obtener la información del proceso de atención de reclamos.

- Con la información obtenida por el banco sobre sus procesos y actividades del área de atención al cliente, se elaboraran flujogramas describiendo el proceso de atención de reclamos y una matriz de riesgo que servirá como punto de partida para la ejecución de la auditoría basada en riesgos.

- Se obtiene conocimiento acerca de los objetivos de la organización y del área.

- Se evalúa el funcionamiento del sistema de control interno en base al cumplimiento de objetivos de la organización y del área.

- Determinar brechas en el sistema de control interno.

- Elaboración de las conclusiones del proyecto.

- Elaborar el informe de investigación y presentar los resultados. 
Figura 3.1: Proceso de Auditoría Basada en Riesgos

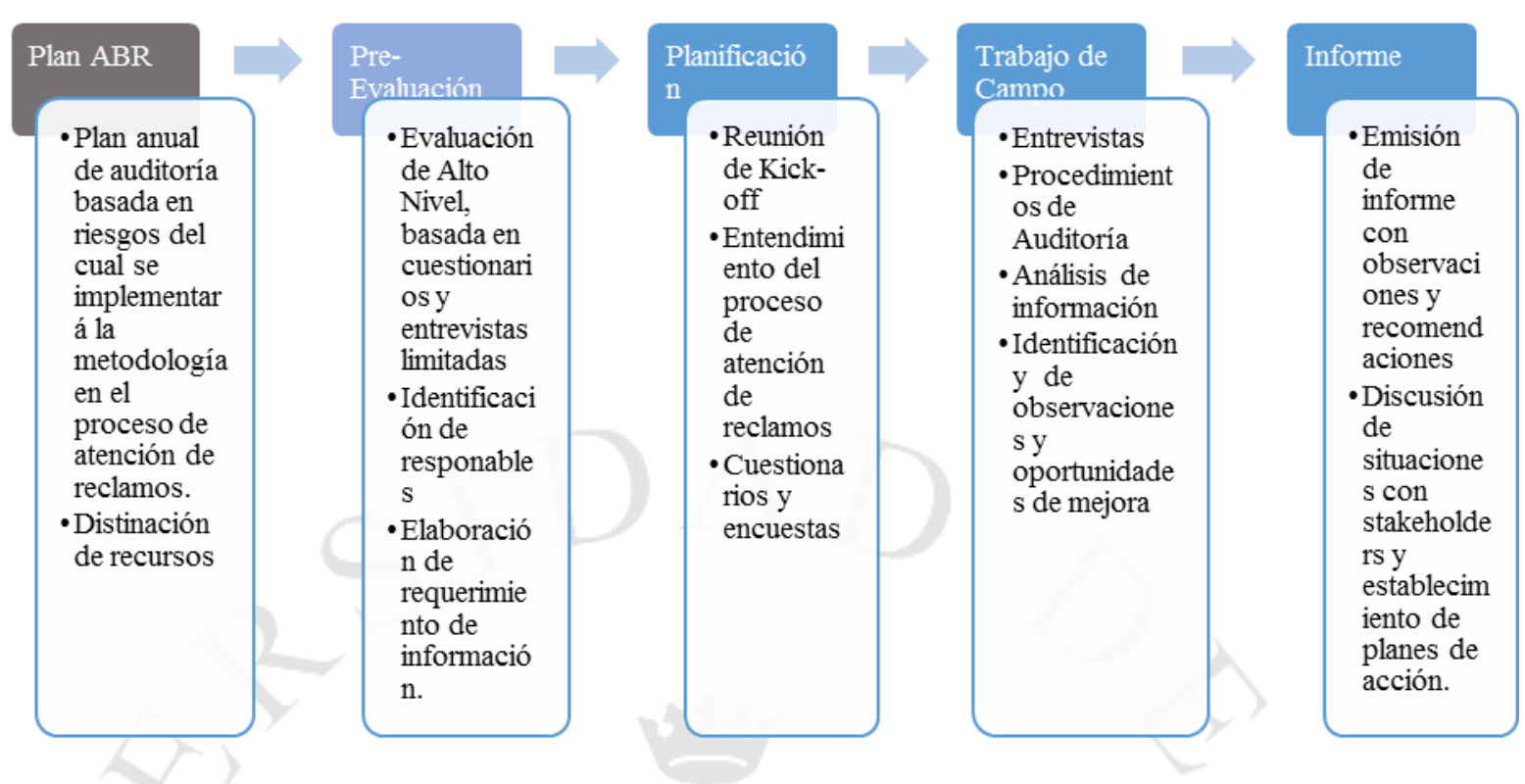

Fuente: Elaboración Propia.

\subsection{Presentación de resultados}

Demostrar que realizar una auditoría basada en riesgos permite generar valor a la organización. La metodología sigue un programa de trabajo el cual contempla el cumplimiento de objetivos de la organización y los riesgos que impedirían alcanzarlos.

Así mismo, las recomendaciones establecidas por el área de auditoría interna se basan en la técnica de identificar la raíz del problema, con ello se realiza un trabajo conjunto con el dueño del proceso a fin de determinar la causa de la debilidad y evitar que vuelva a suceder en el futuro con ello se aporta valor a los procesos y a la organización con lo que se cubrirían las expectativas de los stakeholders (principales funcionarios de la compañía). 


\section{CAPÍTULO 4: MARCO TEÓRICO}

\subsection{Base regulatoria}

\subsubsection{Normas aplicables a la ejecución de la función de auditoría interna}

La Superintendencia de Banca, Seguros y AFP, cumpliendo el rol de supervisión a las empresas del sector financiero, ha emitido las siguientes normas:

- Reglamento de la Gestión Integral de Riesgos - Resolución SBS No 37-2008, emitida el 10.01.2008

- Reglamento de Auditoria Interna - Resolución SBS N 11699-2008, emitida el 28.11.2008

- Gestión de la Continuidad del Negocio - Circular N G-139-2009, emitida el 02.04.2009

- Evaluaciones internas y externas de la auditoria interna - Circular N ${ }^{\circ}$ G-1612012, emitida el 27.01.2012

La Resolución $\mathrm{N}^{\circ}$ 37-2008 contempla, entre otros aspectos, la definición de gestión integral de riesgos, sus componentes, tipos de riesgos, relación de la gestión integral de riesgos con el sistema de control interno; así como, las responsabilidades del Directorio, de la Gerencia y de los diversos Comités. Dicha normativa está orientada básicamente a impartir lineamientos al Directorio, Gerencia y personal de la Compañía para que diseñe procesos en base a evaluación de riesgos los que permitirán identificar, gestionar, minimizar y monitorear posibles eventos que puedan afectar el logro de los objetivos estratégicos de la Compañía.

La Resolución № 11699-2008 incluye, principalmente, disposiciones referidas a las funciones de la Unidad de Auditoria Interna, al Plan Anual de Trabajo de Auditoria Interna, sus Informes (programados y especiales), las actividades obligatorias y las responsabilidades del Comité de Auditoria y Gerente de Auditoria Interna. 
La Circular N G-139-2009 señala que la gestión de la continuidad del negocio es un proceso, efectuado por el Directorio, la Gerencia y el personal, que implementa respuestas efectivas para que la operatividad del negocio de la empresa continúe de una manera razonable, con el fin de salvaguardar los intereses de sus principales grupos de interés, ante la ocurrencia de eventos que pueden crear una interrupción o inestabilidad en las operaciones de la empresa, por lo que dicha norma se establece la obligatoriedad de efectuar diversas acciones a fin de garantizar que la Compañía seguirá operando en situaciones que pudieran afectar los sistemas operativos.

La Circular $\mathrm{N}^{\circ}$ G-161-2012 señala que las empresas deberán realizar evaluaciones internas y externas del desempeño de la función de auditoría interna.

Las evaluaciones internas deberán ser periódicas, cuando menos anualmente. En el caso del servicio de auditoría de sistemas, las evaluaciones internas deberán tomar en cuenta el cumplimiento de las directrices de auditoría emitidas por ISACA.

Las evaluaciones externas deben ser realizadas al menos una vez cada cinco años, y serán realizadas por un revisor o equipo de revisión que acredite contar con el conocimiento y experiencia requerida, que no se encuentre relacionado con la empresa mediante vínculos de gestión o propiedad y que no haya realizado actividades de consultoría a la empresa en temas relacionados con la función de auditoría interna durante los dos años anteriores al inicio de la revisión. Las evaluaciones externas a las que hace referencia las normas 1300 y 1312, deben ser realizadas al menos una vez cada cinco años.

\subsubsection{Normas aplicables al proceso de atención de reclamos}

\section{Circular G146- 2009}

La circular en mención, publicada en diciembre del 2009 establece las disposiciones aplicadas a las empresas reguladas por la superintendencia de Banca, Seguros y AFP. El contenido de la norma regula el proceso de atención de reclamos en lo referido a:

Contar con un sistema de atención al usuario

Contar procedimientos de atención de reclamos ordinarios y los provenientes de entidades gubernamentales. 
$\checkmark$ Requerimiento del área de atención al usuario

$\checkmark$ Responsabilidad del encargado del proceso de atención al usuario.

$\checkmark$ Presentación de informes de gestión

$\checkmark$ Plazo máximo de atención de reclamos y el cómputo de los plazos.

$\checkmark$ Indicadores de Gestión.

Difusión de información de Reclamos recibidos a través de la página web

\subsection{Auditoría interna}

\subsubsection{Definición}

La auditoría interna es una actividad independiente y objetiva de aseguramiento y consulta, concebida para agregar valor y mejorar las operaciones de una organización. Ayuda a una organización a cumplir sus objetivos aportando un enfoque sistemático y disciplinado para evaluar y mejorar la eficacia de los procesos de gestión de riesgos, control y gobierno. (IAI 2013, 17).

El objetivo de la auditoría interna va enfocado a ayudar a la administración en su gestión, por medio de recomendaciones que perfeccionan de forma constante a la organización y garantizan el cumplimiento de sus objetivos y metas de manera razonable, derivado del análisis de sus operaciones y procesos.

\subsubsection{Objetivo}

El objetivo de la auditoría interna es ayudar a la organización en el cumplimiento de sus objetivos: estratégicos y relacionados (de información, operativos y de cumplimiento), agrega valor a la organización por medio del mejoramiento de sus operaciones, aplica un enfoque sistemático y disciplinado en la evaluación de los procesos de gestión de riesgos, control y gobierno y realiza las recomendaciones y comentarios a los mismos.

\subsubsection{Importancia}

La importancia de la auditoria consiste en ayudar a la organización al mantenimiento de un control interno adecuado por medio de su evaluación, que permita garantizar de forma razonable el logro de objetivos relacionados en las categorías de confiabilidad de la información financiera, eficacia y eficiencia operativa, salvaguarda de los activos y 
el cumplimiento de políticas, planes, procedimientos leyes y reglamentos, asimismo de los objetivos estratégicos de la institución.

El rol principal de la auditoría interna con respecto a ERM es proporcionar aseguramiento objetivo al consejo de administración respecto de la eficacia de las actividades de ERM de una empresa, para ayudar a garantizar que los riesgos clave del negocio se están gestionando correctamente y que el sistema de control interno está funcionando eficazmente. (IAI, "Position Paper", 2004)

La auditoría interna es, en sí, un control de controles en una organización, posee independencia y objetividad para lograr su fin.

\subsubsection{Metodología}

La metodología en la realización de una auditoría interna puede variar conforme el criterio del gerente de auditoría interna, sin embargo, conforme al cumplimiento de las normas internacionales de auditoría interna esta debe evaluar diariamente los procesos de gestión de riesgos, control y gobierno y se puede tomar de modelo las siguientes etapas en la realización de una auditoria de gestión de riesgos:

\section{a. Pre-Auditoría}

Es una etapa inicial de conocimiento del área o proceso a nivel general a evaluar en la institución, se debe buscar, seleccionar, comprender y analizar todo tipo de información de la forma en que se desarrollan sus actividades. En esta fase se establecen los objetivos preliminares, la naturaleza, oportunidad y alcance preliminar, pero estos pueden cambiar y dependen de la conclusión obtenida en la evaluación del control interno.

\section{b. Planificación}

Las actividades de la auditoria están basadas en el plan anual de auditoría interna, debe apoyarse en la evaluación de riesgos e incluir el alcance, objetivos, plazo y asignación de recursos. El plan es aprobado generalmente por el comité de auditoría, sobre este se basa el motivo de una revisión en las distintas áreas de una institución por el que posteriormente se realiza un programa a la medida. 
El programa de auditoría se basa en la evaluación de control interno, se deben considerar los objetivos del área a auditar, los riesgos y controles establecidos en su elaboración, así mismo la asignación de los distintos tipos de recursos tales como humanos, físicos, tecnológicos, etc., en su realización. En este se determina la naturaleza, oportunidad y alcance de los diferentes tipos de pruebas a realizar en la ejecución. Las pruebas deben estar basadas en los objetivos de auditoría, en los casos en que no existan controles o tengan debilidades significativas las pruebas deben realizarse conforme a los posibles errores y fraudes como consecuencia de la falta de controles apropiados.

\section{Evaluación de control interno}

Constituye la base de la auditoria de basada en riesgos, se debe considerar que la gestión de riesgos debe estar alineada con la misión/visión institucional, objetivos estratégicos, objetivos de negocio, los riesgos y controles para mitigarlos.

En esta etapa debe analizar los ocho elementos del control interno y gestión de riesgos corporativa, en esta fase de la auditoria se pretende:

$\checkmark$ Obtener el análisis de la gestión de riesgos y de los componentes del control interno.

$\checkmark$ Analizar la operación, función o actividad a evaluar.

Extraer una conclusión preliminar sobre la efectividad del sistema de control Interno y de los riesgos existentes.

$\checkmark$ Determinar las pruebas necesarias para concluir la documentación de las

$\checkmark$ Actividades de control analizadas.

$\checkmark$ Evaluación de objetivos, riesgos y control.

\section{Evaluación de objetivos, riesgos y control.}

Se debe concluir en forma adecuada acerca de las actividades de control implementadas en los procesos y este puede evaluarse con los siguientes pasos conforme al ERM: 
- Identificación de los objetivos del negocio,

- Alineación con los objetivos estratégicos,

- Determinación de los factores de riesgo y la probabilidad e impacto para calificar el riesgo y

- Evaluación de las actividades de control.

- Según el resultado de la evaluación de las actividades de control se debe realizar una revisión y ajuste de los objetivos de auditoría preliminares para determinar si se pueden ejecutar y alcanzar.

\section{c. Trabajo de Campo}

Se ejecutaran o realizaran todos los procedimientos establecidos en el programa de auditoría, por medio de las diversas herramientas y técnicas de auditoría, con el objeto de obtener la evidencia suficiente y competente que respalde los resultados obtenidos derivado del análisis y evaluación de las pruebas ejecutadas, sobre los cuales el auditor basara sus conclusiones y recomendaciones.

En la ejecución se obtienen las conclusiones definitivas del sistema de control y de los riesgos.

"Los auditores internos deben realizar una evaluación preliminar de los riesgos relevantes para la actividad bajo revisión. Los objetivos del trabajo deben reflejar los resultados de esta evaluación". (IAI, 2013, Norma 2210.A1)

El auditor interno debe considerar la probabilidad de errores, fraude, incumplimientos y otras exposiciones significativas al elaborar los objetivos del trabajo." (IAI 2013, Norma 2210.A2)

\section{d. Informe}

Es el producto final del auditor, en el que se expone y comunica los resultados obtenidos de la auditoria por escrito. El informe de auditoría se 
fundamenta en la evidencia suficiente, competente y pertinente obtenida en las fases de la auditoria, con el fin de brindar suficiente información sobre los desvíos o deficiencias más importantes como sus debidas recomendaciones.

Este va dirigido a altos niveles dentro de la organización en los que se incluye al comité de auditoría, directores y gerentes. Conforme lo establece la norma internacional de auditoría interna 2420 "Calidad de la comunicación" estas deben ser precisas, objetivas, claras, concisas, constructivas, completas y oportunas.

El informe de auditoría interna debe ser discutido durante el transcurso de la auditoria o bien por medio de una reunión de cierre posterior a su finalización, con el objeto de emitir recomendaciones y agregar valor a las operaciones.

Entre los componentes mínimos que debe incluir el informe tenemos los siguientes:

- Los objetivos de la auditoria,

- El alcance,

- Conclusión del control interno y administración de los riesgos,

- Los hallazgos,

- Las recomendaciones,

- Los comentarios y

- El plan de acción.

\section{e. Seguimiento}

Una vez se han emitido el informe y se ha consensuado con la administración sobre el plan de acción, el auditor interno debe verificar si se cumplen con las fechas y acciones acordadas de los hallazgos obtenidos de la auditoria. 
El seguimiento se define como "un proceso por el cual los auditores internos evalúan la adecuación, eficacia y oportunidad de las medidas tomadas por la dirección con relación a las observaciones y recomendaciones del trabajo, incluso aquellas efectuadas por los auditores externos y otros. Este proceso también incluye determinar si la alta dirección o el consejo de administración han asumido el riesgo de no tomar medidas correctivas sobre las observaciones informadas." (IAI, 2013, Consejo para la práctica 2500.A1-1).

EI seguimiento debe ser programado entre el trabajo del auditor, debe tomarse muy en cuenta la exposición al riesgo en aquellos asuntos considerados delicados conforme al impacto que pudieran tener en la institución sino se toman las acciones correctivas.

\section{f. Supervisión}

La supervisión es constante y no constituye una fase de auditoría ya que es llevada a cabo en todas las demás fases desde la pre auditoria al seguimiento de las recomendaciones. Esta es asignada a un supervisor que tenga los conocimientos técnicos, pericia y preparación necesaria en el área o proceso a auditar, para asegurar que se cumplan los objetivos planteados de auditoría, la realización de un trabajo con calidad y se promueva profesionalmente el desarrollo del personal.

"El director de auditoría interna tiene la responsabilidad general de la supervisión del trabajo, ya sea que haya sido desempeñado por la actividad de auditoría interna o para ella, pero puede designar a miembros adecuadamente experimentos de la actividad de auditoría interna para llevar a cabo esta tarea. Se debe documentar y conservar evidencia adecuada de la supervisión." (IAI, 2013, Marco internacional para la práctica profesional de la auditoría interna).

Debe de quedar evidenciado adecuadamente su realización en un papel de trabajo con las observaciones en las distintas etapas. 


\section{g. Documentación}

Adicionalmente a la metodología descrita anteriormente es importante considerar los papeles de trabajo, pruebas de auditoría y técnicas de evaluación del control interno como se especifica a continuación:

\section{Papeles de trabajo.}

Son aquellos registros realizados por el auditor y en los que deja plasmados los procedimientos de auditoría, estos deben de contar con la evidencia suficiente y competente que respalden adecuadamente los resultados obtenidos. Estos pueden estar constituidos en hojas de papel, fotocopias, films, disquetes, discos u cualquier otro tipo de medio. Son propiedad de la organización y deben ser administrados por la auditoría interna. La ley general de banca, seguros y AFP establece un periodo de resguardo de 10 años.

Para su resguardo se pueden conservar en un archivo permanente y corriente. El archivo permanente incluye información relevante de la organización como actas del consejo de administración o asamblea de accionistas, políticas y procedimientos de operación, descripción y naturaleza de la empresa, etc., esta información se puede guardar para subsecuentes revisiones y cualquier tipo de consulta. El archivo corriente incluye información de la auditoría realizada en el periodo y esta puede ser la planificación, cedulas de auditoría, informe, entre otros.

\section{Pruebas de auditoría y técnicas de evaluación del control interno}

Las pruebas que realiza la auditoria se dividen en pruebas de control, sustantivas y de doble propósito.

$\checkmark$ Pruebas control: denominadas también de cumplimiento, son aquellos procedimientos que van encaminados a verificar la efectividad de la operación y diseño de una política o procedimiento del control interno. 
Pruebas de sustantivas: son las que tienen por objetivo verificar la exactitud, integridad y validez de los saldos y transacciones de los estados financieros para asegurar la confiabilidad en la información generada.

Pruebas de doble propósito: son aquellas que persiguen ser de control y a la vez sustantivas.

En la evaluación del control interno se pueden utilizar las técnicas de flujogramas de procesos, cuestionarios y narrativas de procedimientos y procesos. Estas herramientas pueden ayudar a determinar las deficiencias en el funcionamiento del control.

\subsection{Marco para la práctica de auditoría Interna}

The Institute of Internal Auditors (IIA) o Instituto de Auditores Internos es una asociación internacional dedicada al desarrollo profesional continuado del auditor interno y la profesión de auditoría interna, este engloba a los profesionales de la auditoría interna a nivel mundial.

La profesión de auditoría interna actualmente y conforme a estándares internacionales se desarrolla por medio de las Normas Internacionales para el Ejercicio de la Auditoría Interna, que son promovidas por el IIA y constituyen el marco para la práctica profesional.

\subsubsection{Código de ética}

El instituto promueve un código de ética can la finalidad de promover una cultura ética en la profesión de la auditoría interna y es aplicable para todas las personas o entidades que prestan servicios de auditoría interna. Este se divide en principios y reglas de conducta. Los principios y las reglas están compuestos por integridad, objetividad, confidencialidad, y competencia. 


\subsubsection{Normas internacionales de auditoría interna}

En el desarrollo profesional de la auditoría interna las normas establecen la base teórica por medio de principios básicos, que sirven de marco de referencia en la evaluación del desempeño, mejoras a los procesos y recomendaciones para agregar valor a la entidad. Las normas internacionales de auditoría interna se dividen:

a. Normas sobre atributos. Se conforma por las características de los individuos y organizaciones que desarrollan auditoría interna. Entre estas tenemos las siguientes:

$\checkmark 1000$ - Propósito, autoridad y responsabilidad,

$\checkmark 1100$ - Independencia y objetividad,

$\checkmark 1200$ - Aptitud y cuidado profesional y

$\checkmark 1300$ - Programa de aseguramiento de calidad.

b. Normas sobre desempeño. Describen la naturaleza de las actividades de auditoría interna y los criterios de calidad para evaluar el desempeño de los servicios. A continuación se listan las mismas:

$\checkmark 2000$ - Administración de la actividad de auditoría interna,

$\checkmark 2100$ - Naturaleza del trabajo,

$\checkmark 2200$ - Planificación del trabajo,

$\checkmark 2300$ - Desempeño del trabajo,

$\checkmark 2400$-Comunicación de resultados,

$\checkmark 2500$-Supervisión del progreso y

$\checkmark 2600$ - Decisión de aceptación de los riesgos por la dirección.

A continuación se describen algunas de las más importantes normas internacionales de auditoría interna:

\section{Propósito, autoridad y responsabilidad}

El propósito, autoridad y responsabilidad de la auditoria deben estar establecidos en un estatuto de auditoría interna, que es aprobado por el consejo de administración de una 
organización. En el mismo se definirán la naturaleza de los servicios de consultoría y aseguramiento que se prestaran a la entidad. (IAI, 2013, Norma 1000).

\section{Independencia y objetividad}

"La actividad de auditoría interna debe ser independiente, y los auditores internos deben ser objetivos en el cumplimiento de su trabajo." (IAI, 2013, Norma 1100).

Los auditores internos al realizar su trabajo deben tener la independencia necesaria para ejercer la función de auditoría interna de manera adecuada, al reportar directamente al consejo de administración, junta directiva, comité de auditoría u órgano equivalente en la organización, así mismo, ser objetivos al ejecutar su trabajo garantizan al auditor una actitud libre, imparcial y equilibrada para emitir sus conclusiones sin que pueda influir en su juicio otra persona.

\section{Aptitud y cuidado profesional}

"Los trabajos deben cumplirse con aptitud y cuidado profesional adecuados". (IAI, 2013, Norma 1200).

El auditor interno debe contar con la suficiente aptitud en la realización de su trabajo, al hablar de la aptitud nos referimos a las habilidades y experiencia suficiente para ejecutar el trabajo en las distintas industrias en que se desempeñe. A la mano de la aptitud se encuentra el cuidado profesional que son las aptitudes para que el auditor realice su trabajo de manera prudente y razonable, y esta la obtiene en su preparación, estudio y actualización continua en las distintas disciplinas relacionadas a su trabajo o aquellas que le puedan auxiliar en su cometido.

\section{Administración de la actividad de auditoría interna}

"El director de auditoría interna debe gestionar eficazmente la actividad de auditoría interna para asegurar que añada valor a la organización”. (IAI, 2013, Norma 2000).

Al igual que cualquier departamento, en una empresa la auditoria debe ser gestionada para que agregue valor a la organización. La auditoría debe establecer una planificación basada en la administración y gestión de riesgos, los cuales deben ser 
evaluados en una planificación anual y al mismo tiempo debe ser aprobado por el consejo de administración y alta dirección.

El director de auditoría debe velar porque su departamento cuente con los recursos, físicos, humanos y tecnológicos que le permitan realizar su labor y de existir alguna limitación comunicar el impacto que tendrá en su trabajo.

El trabajo realizado por auditoria interna debe estar basado en un manual que establezca las políticas y procedimientos en las actuaciones de los auditores.

\section{Naturaleza del trabajo}

"La actividad de auditoría interna debe evaluar y contribuir a la mejora de los procesos de gobierno, gestión de riesgos y control, utilizando un enfoque sistemático y disciplinado." (IAI, Norma 2100).

En los procesos de la naturaleza del trabajo la auditoría interna promueve la mejora continua y realiza lo siguiente:

- Gestión de riesgos: identifica y evalúa las posibles exposiciones al riesgo.

- Control interno: realiza evaluaciones del control para su mantenimiento eficaz y efectivo.

- Gobierno: evalúa el proceso de gobierno corporativo respecto al cumplimiento de los objetivos de promover ética y valores, comunicar eficazmente información de riesgos y controles, asegurar gestión de la responsabilidad en el desempeño y coordinar eficazmente la comunicación entre el consejo de administración, la dirección y los auditores internos y externos.

\section{Planificación del trabajo}

"Los auditores internos deben elaborar y documentar un plan para cada trabajo, que incluya su alcance, objetivos, tiempo y asignación de recursos". (IAI, 2013, Norma 2200).

\section{Consejos para la práctica}


Son los consejos que incluyen las mejores prácticas para la aplicación de las normas de auditoría. Estos están compuestos por las normas de atributos y las de desempeño. Los consejos son de carácter ilustrativo y no obligatorio y enmarcan la actuación de la auditoria en los distintos tipos de situaciones que se puedan encontrar al desempeñar su trabajo.

\subsection{Marco de control interno basado en gestión de riesgos de la empresa}

\subsubsection{Definición de ERM (Enterprise Risk Management)}

"Es un proceso efectuado por el consejo de administración, la dirección y el resto del personal de una entidad, diseñado con el propósito de proporcionar un grado de seguridad razonable en cuanto a consecución de objetivos dentro de las siguientes categorías: eficacia y eficiencia de las operaciones, fiabilidad de la información financiera y cumplimiento de leyes y normas aplicables". (Committee of Sponsoring Organizations of the Treadway Commission [COSO], 2004).

Publicado en 1992 por el Comitte of The Sponsoring of Treadway Commission, orientado al análisis y examen de control desde una perspectiva de dirección orientada a resultados. Los componentes de este sistema son el entorno de control, evaluación de riesgos, actividades de control, información y comunicación y supervisión".

El COSO ERM (Enterprise Risk Management) es una sucesión del COSO (Comitte of The Sponsoring of Treadway Commission) marco integrado derivado que a nivel mundial, se tiene una conciencia orientada hacia la gestión de riesgos, y, es originada por los escándalos mercantiles, fallos donde los inversionistas, grupos de interés y demás personas han sufrido pérdidas a través de los últimos arios, derivado de ello han surgido leyes como la Sarbanex Oxley de 2002 en EEUU y otras legislaciones similares en diferentes países para gestionar los riesgos. Es por ello que ha surgido este nuevo enfoque COSO orientado a los riesgos, para dar seguridad razonable acerca de la eficacia y eficiencia de las operaciones, fiabilidad de la información financiera y el cumplimiento de leyes y normas que sean aplicables.

La importancia de este nuevo concepto radica en que logró uniformar y definir lo que es el control interno, se compilo las ideas y criterios aportados por las personas 
participantes en la elaboración del informe COSO marco integrado. Anteriormente las empresas, profesionales, legisladores, reguladores entre otros, tenían su propio concepto de lo que era el control interno como tal lo que origin6 problemas de comunicación y de resultados esperados.

\subsubsection{Objetivos}

El objetivo del control interno es ayudar a cumplir con los objetivos de la organización al evitar, mitigar o medir las dificultades que se puedan realizar en el camino.

Dentro del contexto de misión o visión establecida en una entidad, su dirección establece los objetivos estratégicos, selecciona la estrategia y fija objetivos alineados que fluyen en cascada en toda la entidad. El Marco de Gestión de Riesgos Corporativos está orientado a alcanzar los objetivos de la entidad, que se pueden clasificar en cuatro categorías:

- Estrategia: objetivos a alto nivel, alineados con la misión de la entidad y dándole apoyo.

- Operaciones: objetivos vinculados al use eficaz y eficiente de los recursos.

- Información: objetivos de fiabilidad de la información suministrada.

- Cumplimiento: objetivos relativos al cumplimiento de leyes y normas aplicables.

Esta clasificación de los objetivos de una entidad permite centrarse en aspectos diferenciados de la gestión de riesgos corporativos. Estas categorías distintas se dirigen a necesidades diferentes de la entidad y pueden ser de responsabilidad directa de diferentes ejecutivos. También permiten establecer diferencias entre lo que cabe esperar de cada una de ellas. Otra categoría utilizada por algunas entidades es la salvaguarda de los activos". (Committee of Sponsoring Organizations of the Treadway Commission [COSO], 2004).

\subsubsection{Componentes}

El COSO ERM consta de ocho componentes que se relacionan entre sí, y se derivan de la filosofía de la dirección de la empresa y como se integran en el proceso de gestión. 
Entre los objetivos que la organización desea lograr y los componentes anteriormente descritos existe una relación directa, ya que representa lo que hace falta para lograrlos

"La gestión de riesgos corporativos no constituye estrictamente un proceso en serie, donde cada componente afecta solo al siguiente, sino un proceso multidireccional e iterativo que en casi cualquier componente puede influir en otro". (Committee of Sponsoring Organizations of the Treadway Commission [COSO], 2004).

Los componentes según el orden que se desarrollan son los siguientes:

\section{- Ambiente interno}

"El ambiente interno abarca el talante de una organización, que influye en la conciencia de sus empleados sobre el riesgo y forma la base de los otros componentes de la gestión de riesgos corporativos, proporcionando disciplina y estructura. Los factores del ambiente interno incluyen la filosofía de gestión de riesgos de la entidad, su riesgo aceptado, la supervisión ejercida por el consejo de administración, la integridad, valores éticos y competencia de su personal y la forma en que la dirección asigna la autoridad y responsabilidad y organiza y desarrolla a sus empleados.". (Committee of Sponsoring Organizations of the Treadway Commission [COSO], 2004).

\section{- Establecimiento de Objetivos}

"Los objetivos se fijan a esc

ala estratégica, estableciendo con ellos una base para los objetivos operativos, de información, y de cumplimiento. Cada entidad se enfrenta a una gama de riesgos procedentes de fuentes externas e internas y una condición previa para la identificación eficaz de eventos, la evaluación de sus riesgos y la respuesta a ellos es fijar los objetivos, que tienen que estar alineados con el riesgo aceptado por la entidad, que orienta a su vez los niveles de tolerancia at riesgo de la misma". (Committee of Sponsoring Organizations of the Treadway Commission [COSO], 2004).

\section{- Identificación de Riesgos}


"La dirección identifica los eventos potenciales que, de ocurrir, afectaran a la entidad y determina si representan oportunidades o si pueden afectar negativamente a la capacidad de la empresa para implantar la estrategia y lograr los objetivos con éxito. Los eventos con impacto negativo representan riesgos, que exigen la evaluación y respuesta de la dirección. Los eventos con impacto positivo representan oportunidades, que la dirección reconduce hacia la estrategia y el proceso de fijación de objetivos. Cuando identifica los eventos, la dirección contempla una serie de factores internos y externos que pueden dar lugar a riesgos y oportunidades, en el contexto del ámbito global de la organización". (Committee of Sponsoring Organizations of the Treadway Commission [COSO], 2004).

\section{- Evaluación de Riesgos}

"La evaluación de riesgos permite a una entidad considerar con que los eventos potenciales impactan en la consecución de los objetivos. La dirección evalúa estos acontecimientos desde una doble perspectiva; probabilidad e impacto, y normalmente usa una combinación de métodos cualitativos y cuantitativos. Los impactos positivos y negativos de los eventos potenciales deben examinarse, individualmente o por categoría, en toda la entidad. Los riesgos se evalúan con un doble enfoque: riesgo inherente y riesgo residual". (Committee of Sponsoring Organizations of the Treadway Commission [COSO], 2004).

\section{- Respuesta a los Riesgos}

"Una vez evaluados los riesgos relevantes, la dirección determina como responder a ellos. Las respuestas pueden ser las de evitar, reducir, compartir y aceptar el riesgo. Al considerar su respuesta, la dirección evalúa su efecto sobre la probabilidad e impacto del riesgo, así como los costes y beneficios, y selecciona aquella que situé el riesgo residual dentro de las tolerancias al riesgo establecidas. La dirección identifica cualquier oportunidad que pueda existir y asume una perspectiva de la cartera de riesgos, determinando si el riesgo residual global concuerda con el riesgo aceptado por la entidad". (Committee of Sponsoring Organizations of the Treadway Commission [COSO], 2004). 


\section{- Actividades de Control}

"Las actividades de control son las políticas y procedimientos que ayudan a asegurar que se llevan a cabo las respuestas de la dirección a los riesgos. Las actividades de control tienen lugar a través de la organización, a todos los niveles y en todas las funciones. incluyen una gama de actividades tan diversas como aprobaciones, autorizaciones, verificaciones, conciliaciones, revisiones del funcionamiento operativo, seguridad de los activos y segregación de funciones". (Committee of Sponsoring Organizations of the Treadway Commission [COSO], 2004).

\section{- Tipos de controles}

El control interno es y será motivo de preocupación para la administración en el cumplimiento de los objetivos institucionales en las distintas áreas. Para el auditor dependerá mucho la confianza que ponga en este, al momento de la aplicación de las pruebas para su auditoria. Por tal motivo es importante conocer algunos conceptos generales acerca del control interno como tal.

Con el objetivo de asegurar la solides en la estructura y ambiente de control en el banco, el control interno debe cumplir con criterios básicos relacionados con los siguientes tipos de controles:

- Preventivos. Son los que se anticipan a los posibles riesgos en una institución antes de que impacten en la organización.

- Detectivos: Identifican los riesgos, errores e irregularidades en tiempo.

\section{- Información Comunicación}

"La información pertinente se identifica, capta y comunica de una forma y en un marco de tiempo que permiten a las personas llevar a cabo sus responsabilidades. Los sistemas de información usan datos generados internamente y otras entradas de fuentes externas y sus salidas informativas facilitan la gestión de riesgos y la toma de decisiones informadas relativas a los objetivos. También existe una comunicación eficaz fluyendo en todas 
direcciones dentro de la organización. Todo el personal recibe un mensaje claro desde la alta dirección de que deben considerar seriamente las respuestas de gestión de riesgos corporativos. Las personas entienden su papel en dicha gestión y como las actividades individuales se relacionan con el trabajo de los demás. Asimismo, debe haber una comunicación eficaz con terceros, tales como clientes, proveedores, reguladores y accionistas". (Committee of Sponsoring Organizations of the Treadway Commission [COSO], 2004).

\section{- Monitoreo}

"La gestión de riesgos corporativos se supervisa revisando Ia presencia y funcionamiento de sus componentes a lo largo del tiempo, lo que se lleva a cabo mediante actividades permanentes de supervisión, evaluaciones independientes o una combinación de ambas técnicas. Durante el transcurso normal de las actividades de gestión, tiene lugar una supervisión permanente. El alcance y frecuencia de las evaluaciones dependerá fundamentalmente de la evaluación de riesgos y la eficacia de los procedimientos de supervisión permanente. Las deficiencias en la gestión de riesgos corporativos se comunican de forma ascendente, trasladando los temas más importantes a la alta dirección y al consejo de administración". (Committee of Sponsoring Organizations of the Treadway Commission [COSO], 2004).

\subsection{Evaluación del sistema de gestión de riesgos}

\subsubsection{Introducción}

La gestión de riesgos para toda la empresa es un proceso estructurado, coherente y continuo que abarca a toda la organización para identificar, evaluar, afrontar e informar las oportunidades y amenazas que afectan el logro de sus objetivos.

El consejo de administración o directorio tiene la responsabilidad general de asegurar que se gestionen los riesgos. En la práctica, el consejo delega la operación del enfoque de gestión de riesgos al equipo de dirección (Gerencia general y Gerencias adjuntas), el cual será responsable de llevar a cabo las actividades de gestión de riesgos. 
Todos los miembros de la organización desempeñan un rol para el aseguramiento de una gestión exitosa de riesgo empresarial pero la responsabilidad primordial de identificar los riesgos y gestionarlos recae en la dirección.

\section{Ventajas de ERM}

El ERM puede realizar una gran contribución para ayudar a la organización a gestionar los riesgos para el logro de sus objetivos. Las ventajas incluyen:

- Mayor probabilidad de lograr dichos objetivos

- Información consolidada de riesgos dispares en el ámbito del consejo de administración

- Mayor comprensión de los riesgos clave y sus implicancias más amplias

- Identificación e intercambio de conocimientos sobre riesgos de negocio cruzados

- Mayor atención de la dirección a los problemas realmente importantes

- Menos sorpresas o crisis

- Mayor atención internamente para hacer lo correcto de la manera correcta

- Mayor probabilidad de que se logren las iniciativas de cambio

- Capacidad para asumir mayores riesgos en pos de mayores recompensas

- Asunción de riesgos y toma de decisiones más informadas

\section{Actividades incluidas en ERM}

- Expresar y comunicar los objetivos de la organización

- Determinar el grado de aceptación de riesgos de la organización

- Establecer un entorno interno adecuado, que incluya un enfoque de gestión de riesgos

- Identificar las amenazas potenciales para el logro de los objetivos

- Evaluar el riesgo, es decir, el impacto de las amenazas y la probabilidad de que se produzcan

- Seleccionar e implementar respuestas ante los riesgos

- Tomar el control y llevar a cabo otras actividades de respuesta

- Comunicar la información sobre riesgos de manera coherente en todos los niveles de la organización 
- Supervisar y coordinar de forma central los procesos de gestión de riesgos y sus resultados

- Brindar aseguramiento sobre la eficacia con que se gestionan los riesgos

Una de las exigencias claves del consejo de administración u organismo equivalente es obtener el aseguramiento de que los procesos de gestión de riesgos funcionan eficazmente y que los riesgos principales se gestionan para lograr un nivel aceptable.

Es probable que el aseguramiento se obtenga a partir de fuentes diferentes. Entre ellas, el aseguramiento proveniente de la dirección es fundamental. Debe complementarse mediante la provisión de aseguramiento objetivo, para el cual la auditoría interna es una fuente clave. Otras fuentes incluyen la auditoría externa y las revisiones realizadas por especialistas independientes.

La auditoría interna normalmente brinda aseguramiento en tres áreas:

Procesos de gestión de riesgo, en cuanto a su diseño como a su correcto funcionamiento

Gestión de aquellos riesgos clasificados como "clave", incluidos la eficacia de los controles y otras respuestas a esos riesgos

Evaluación confiable y adecuada de los riesgos e información del estado de los riesgos y del control. (IAI, "Position Paper”, 2004, p 3-5).

\subsubsection{El rol de la auditoría interna en la gestión de riesgos para toda la empresa}

La auditoría interna es una actividad independiente y objetiva de aseguramiento y consulta. Su rol fundamental respecto de ERM es brindar un aseguramiento objetivo al consejo de administración en cuanto a la eficacia de la gestión de riesgo. En efecto, las dos maneras más importantes a través de las cuales la auditoría interna agrega valor a la organización son brindando aseguramiento objetivo de que los principales riesgos de negocio se gestionan apropiadamente y de que el enfoque de gestión de riesgo y control interno funciona eficazmente. (IAI, "Position Paper”, 2004, p 5). 
Los factores principales que los directores ejecutivos de auditoría deben tener en cuenta al establecer el rol de la auditoría interna consisten en determinar si la actividad amenaza de alguna manera la independencia y objetividad del auditor interno, y si existe la posibilidad de mejorar los procesos de gestión de riesgos, control y gobierno de la organización. La declaración de posición del IIA indica cuáles son los roles que debe, y que no debe, desempeñar la auditoría interna durante todo el proceso de ERM.

\section{Principales roles de la auditoría interna en relación con ERM.}

$\checkmark$ Otorgar aseguramiento respecto de los procesos de gestión de riesgos.

$\checkmark$ Otorgar aseguramiento respecto de la evaluación correcta de los riesgos.

$\checkmark$ Evaluar los procesos de gestión de riesgos.

$\checkmark$ Evaluar la elaboración de informes sobre los riesgos clave.

$\checkmark$ Revisar la gestión de riesgos clave.

Roles legítimos de la auditoría interna con resguardos.

Facilitar la identificación y evaluación de riesgos.

$\checkmark$ Asesorar a la dirección para responder a los riesgos.

$\checkmark$ Coordinar actividades de ERM.

$\checkmark$ Consolidar la elaboración de informes sobre riesgos.

Mantener y desarrollar el enfoque de ERM.

Defender el establecimiento de ERM.

$\checkmark$ Desarrollar la estrategia de gestión de riesgos para la aprobación por parte del consejo.

\section{Roles que la auditoría interna NO debe desempeñar.}

$\checkmark$ Definir el grado de aceptación de riesgo.

$\checkmark$ Imponer procesos de gestión de riesgos.

$\checkmark$ Tener a su cargo la responsabilidad sobre la gestión de riesgos.

$\checkmark$ Tomar decisiones sobre las respuestas a riesgos.

$\checkmark$ Implementar respuestas para los riesgos en nombre de la dirección.

$\checkmark$ Responsabilidad por la gestión de riesgos. (IAI, "Position Paper", 2004, p 12). 
Como bien se observa en las líneas antes descritas, el instituto de auditores internos (IAI) delimita claramente la responsabilidad de auditoría interna respecto a los servicios de aseguramiento y consultoría estableciendo que se pueden realizar estos últimos siempre que no se desempeñe ningún rol en la gestión efectiva de los riesgos.

Algunos de los roles de consultoría que puede desempeñar la auditoría interna son:

$\checkmark$ Poner a disposición de la dirección las herramientas y técnicas utilizadas por la auditoría interna para analizar riesgos y controles

$\checkmark$ Ser un defensor de ERM al introducirla en la organización, aprovechando su competencia experta en relación con la gestión y control de riesgos, y su conocimiento general de la organización

Brindar asesoramiento, facilitar talleres, capacitar a la organización en materia de riesgos y control, y promover el desarrollo de un lenguaje, enfoque y entendimiento comunes

Actuar como el punto central para coordinar, supervisar e informar riesgos

$\checkmark$ Apoyar a los gerentes en su trabajo de identificar la mejor manera de mitigar un riesgo

\subsubsection{Metodología}

En el enfoque actual de auditoria interna una de las mejores formas de evaluar el control interno y los procesos se basa en planificar y enfocar la auditoria en base a la matriz de riesgos de la institución, en la cual se contemplan los riesgos de la entidad en los negocios que realiza. Este se basara en la alineación de los objetivos y procesos en las unidades administrativas, los riesgos del negocio y los controles implementados para los mismos. Los objetivos y procesos de las unidades deben estar alineados con la estrategia de la entidad.

La función de auditoria es evaluar y verificar que los controles implementados por la administración sean eficientes en la gestión de los riesgos, y la base de la evaluación a utilizar es la establecida por componentes del ERM: 
$\checkmark$ Si la empresa no tiene el proceso formal de gestión de riesgos establecido debe proceder conforme al consejo para la practica 2120 de las normas internacionales para el ejercicio de auditoria interna el cual establece:

$\checkmark$ Si una organización no ha establecido un proceso formal de gestión de riesgos, el director de auditoria interna debe presentar este hecho ante la dirección y el comité de auditoría quienes deben entender, gestionar y vigilar los riesgos de la organización.

$\checkmark \mathrm{Si}$ se lo solicitan, los auditores internos pueden cumplir un rol proactivo colaborando con el establecimiento inicial de un proceso de gestión de riesgos para la organización. Un rol proactivo es el que suplementa las actividades tradicionales de aseguramiento con un enfoque de consultor para mejorar los procesos fundamentales. El auditor puede auxiliarse con el Consejo para la practica 1130.A2 -1: Responsabilidad de Auditoria Interna en Funciones distintas de Auditoria.

Un rol proactivo en el desempeño y manejo de un proceso de gestión de riesgos no es lo mismo que el rol de "ser el propietario de los riesgos".

En resumen los auditores internos pueden facilitar o permitir los procesos de gestión de riesgos, pero no deberían "adueñarse" o ser responsables de la gestión de los riesgos identificados.

\subsubsection{Identificación de Riesgos}

Es el proceso mediante el cual la administración analiza y determina los riesgos que afronta la entidad y que serán la base para la constitución de la gestión de riesgos de la institución. Estos pueden servir como ejemplo para determinar los riesgos en otro tipo de industrias.

\subsubsection{Elaboración de una Matriz de Riesgos}

En la constitución de una matriz de riesgos es necesario identificar los riesgos potenciales que afrontan las entidades, y esta dependerá de la industria en la que desarrollan sus actividades con lo cual será imposible establecer una matriz estándar. Pueden existir factores internos (propios de la industria) y externos como factores 
políticos, sociales y económicos. Para realizar la matriz de riesgos se puede seguir con los siguientes pasos para su elaboración:

$\checkmark$ Identificar los riesgos.

$\checkmark$ Clasificación de las operaciones o procesos conforme a los riesgos potenciales.

$\checkmark$ Desglose de las operaciones por subprocesos o actividades.

$\checkmark$ Determinar la probabilidad e impacto y evaluación de los riesgos.

$\checkmark$ Establecer actividades de control como respuesta a los riesgos. (Nahun Freundt, 2012).

\subsubsection{Clasificación de las operaciones o procesos conforme a los riesgos potenciales}

Se debe de analizar y clasificar las operaciones de la empresa bajo los riesgos potenciales identificados, lo que permite tener una visión global de lo que afronta la organización diariamente.

\subsubsection{Desglose de las operaciones por subprocesos o actividades}

Posteriormente se desglosan los procesos conforme a los distintos subprocesos o actividades que realiza la empresa, para conocer su estructura y orientarlos a su óptimo funcionamiento en relación a los riesgos.

\subsubsection{Determinar la probabilidad e impacto bajo el criterio de auditoría}

Se cuantifica la probabilidad y el impacto de los riesgos potenciales en los procesos con el afán de estimar una respuesta acertada a estos.

Es importante mencionar en este punto que no es posible poder tener un método de cuantificación de la probabilidad e impacto, por lo que el área de auditoría interna del banco ha optado por realizar una estimación cualitativa en base al criterio del evaluador.

\subsubsection{Identificar actividades de control en respuesta a los riesgos}

Al culminar el proceso de la cuantificación de los riesgos en su probabilidad e impacto, la dirección debe darles respuesta por medio de controles que aseguren su adecuada 
gestión. Los caminos para gestionar el riesgo pueden ser de evitar, reducir, compartir o aceptar este.

Es importante indicar que la matriz de riesgos también se puede realizar por unidad funcional o departamento. Su elaboración es similar a la anterior con la diferencia que se clasifican los departamentos de una organización y estos a la vez por los procesos y riesgos que conlleva cada uno.

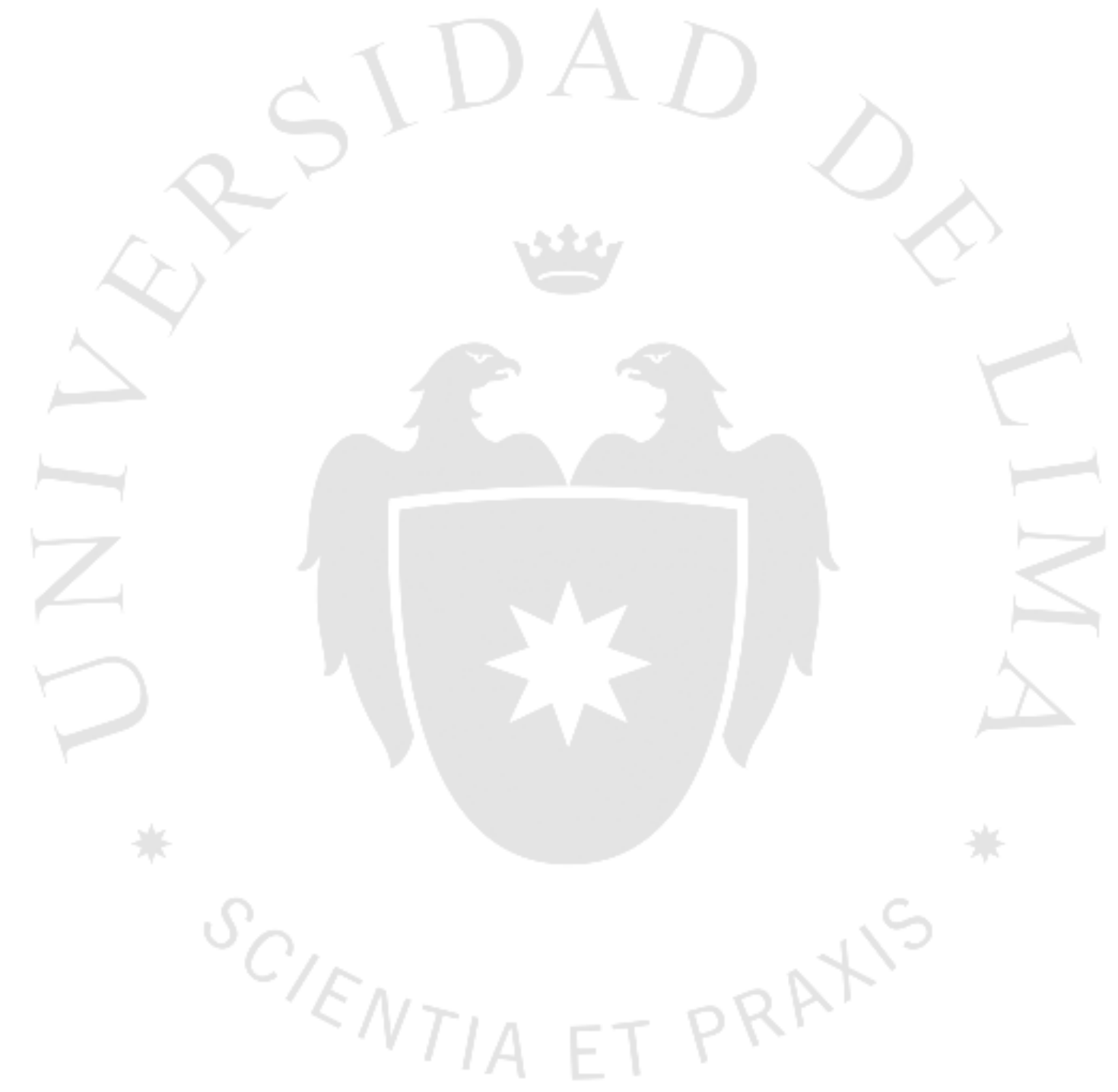




\section{CAPÍTULO 5: ANÁLISIS Y PRESENTACIÓN DE RESULTADOS}

\subsection{Generalidades}

\subsubsection{Información de la entidad financiera}

Con la finalidad de realizar el caso práctico de la investigación, a continuación se describe la información más relevante con tal propósito, por motivos de confidencialidad respecto a la información obtenida de la entidad financiera se denominará para fines prácticos como "El banco".

El banco, es una de las instituciones bancarias más antiguas del país. Desde su llegada en 1920 se encuentra al servicio del desarrollo económico y bienestar de los peruanos.

Actualmente, el banco cuenta con agencias en Lima con la finalidad de ofrecer a sus clientes acceso a diversos canales de pago, el banco mantiene alianzas estratégicas con:

- Boticas FASA: 190 locaciones a nivel nacional

- Global Net: 2,400 ATMs a nivel nacional, que ofrecen servicios de retiros en efectivo, consultas de saldos y disposición de monedas con las mismas tarifas que los cajeros.

- Western Union: 590 locaciones.

El banco mantiene una clasificación de riesgo en el mercado local según Apoyo y Asociados de A+ y por Pacific Credit Rating de A+ con perspectiva estable.

El banco atiende tres líneas de negocio: Banca Corporativa que provee servicios financieros a grandes corporaciones, Banca Local Comercial que atiende a empresas medianas y la Banca de Consumo que atiende la banca personal, además ofrece su propuesta de banca privada. 
Desde sus inicios en nuestro país, y a lo largo de los años 60, 70 y 80, una política medular del Banco fue la constante capacitación de sus funcionarios, siendo reconocido como una verdadera "escuela de banqueros". Pero también capacitaba a personal de otros bancos, incluso del Banco Central de Reserva y de la Superintendencia de Banca y Seguros, quienes seguían los cursos que ofrecía el banco. Toda la currícula de aquellos cursos, incluso algunos profesores, venía desde Nueva York u otros países. El banco introdujo el análisis de riesgos, al ser la única institución que manejaba este tema como práctica habitual.

\subsubsection{Misión y principios}

El banco, líder global tiene aproximadamente 200 millones de cuentas de clientes y realiza negocios en más de 160 países y jurisdicciones.

Ofrece a personas, corporaciones, gobiernos e instituciones una amplia gama de productos y servicios financieros, incluyendo servicios bancarios y de crédito al consumidor, servicios bancarios corporativos y de inversión, corretaje de valores y administración patrimonial. El banco cuenta con cuatro principios clave:

- Objetivo común: Un solo equipo, con un solo objetivo: servir a los clientes, a los accionistas y a las comunidades en donde el banco opera.

- Responsabilidad financiera: Una conducta transparente, prudente y confiable.

- Ingenio: Trabajo direccionado a mejorar la vida de los clientes a través de acciones innovadoras que capitalicen el alcance y la profundidad de la información, de la red global y de los productos de nivel mundial.

- Liderazgo: Personas talentosas y altamente capacitadas, quienes crecen en un ambiente de meritocracia en el que se respeta la diversidad y se exige excelencia, iniciativa y determinación.

\subsubsection{Información del área auditada}

El Banco, cuenta con políticas corporativas en todas sus filiales con la finalidad de estandarizar sus procesos de acuerdo a los lineamientos establecidos por la casa matriz 
la cual cuenta con un sistema de control interno alineado al marco de Enterprise Risk Management.

Cada área es responsable de gestionar adecuadamente los riesgos que haya identificado conjuntamente con el área de Gestión de Riesgos, estos mismos deben evaluarse trimestralmente.

Los procedimientos de control se encuentran respaldados por los manuales de políticas y procedimientos los cuales incluyen sus respectivos flujogramas con lo cual se asegura sostenibilidad del proceso en caso de eventos de rotación de personal.

En tal sentido, se han establecido los siguientes mecanismos para asegurar el cumplimiento de las políticas de control interno:

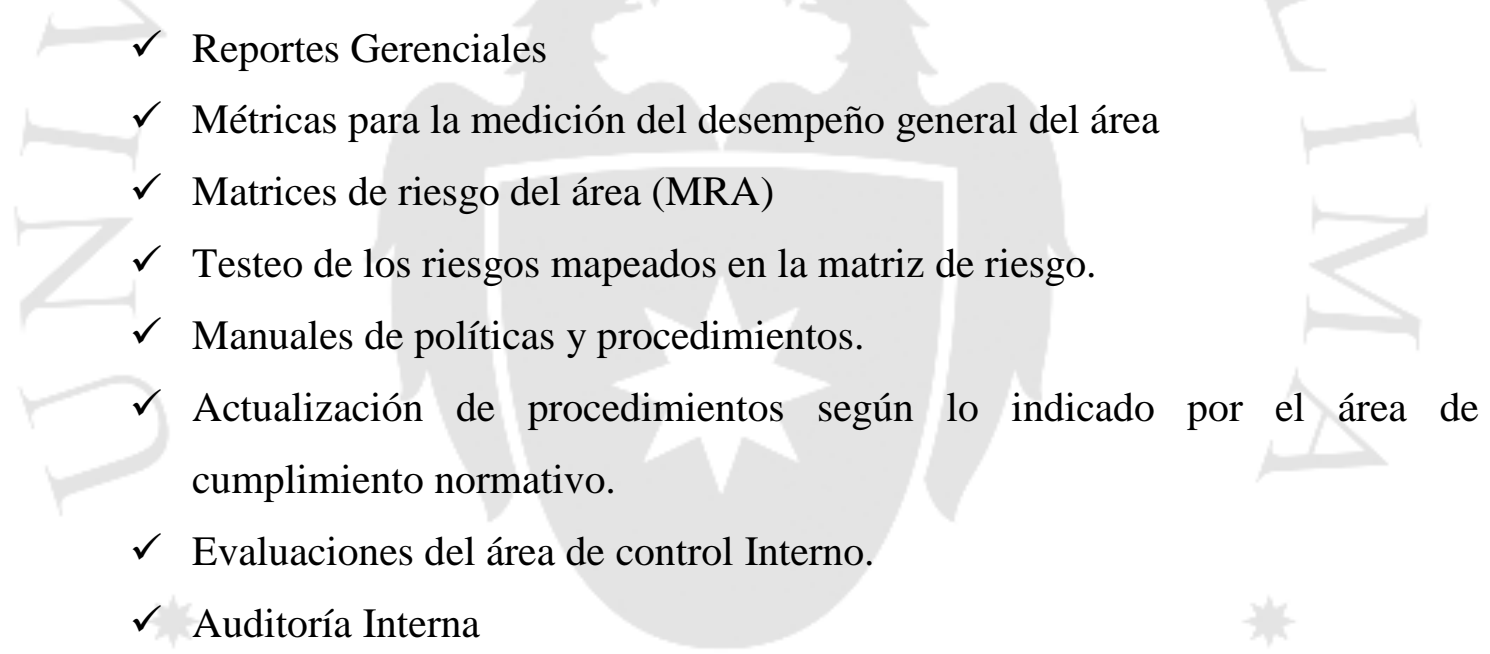

Con respecto a la función de atención de reclamos esta se encuentra a cargo del área de atención al cliente la cual reporta a la Vice presidencia de Operaciones y Tecnología. Dicha área está compuesta de la siguiente manera: 
Figura 5.1 - Organigrama área de atención al usuario

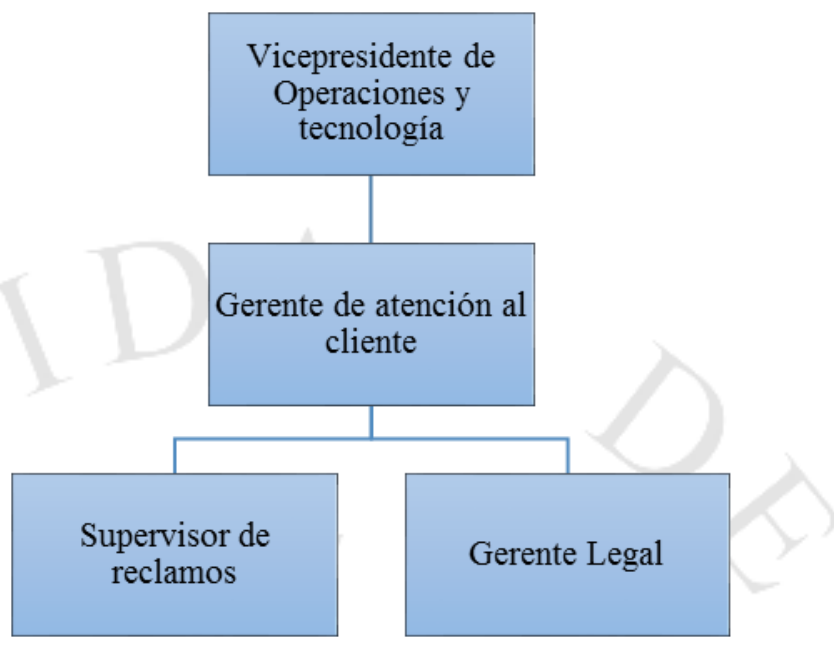

Fuente: Elaboración Propia.

Como se puede observar en el organigrama del área, se cuenta con un Gerente de atención al cliente, un supervisor de atención al cliente a quién reportan seis analistas. Adicionalmente se cuenta con un gerente legal quién realiza la función de atender los reclamos provenientes de entidades regulatorias a quién le reportan dos analistas.

\subsubsection{Auditoría Interna}

La misión de la Unidad de Auditoria Interna (UAI) es proporcionar servicios independientes y objetivos de aseguramiento y consulta, concebidos para agregar valor y mejorar las operaciones de la compañía. Ayuda a cumplir sus objetivos, aportando un enfoque sistemático y disciplinado para evaluar y mejorar la eficacia de los procesos de gestión de riesgos, control y gobierno.

La UAI depende del Directorio y reporta al Comité de Auditoria, teniendo como objetivos determinar si los procesos de gestión de riesgos, control y gobierno de la compañía, son adecuados y funcionan según lo prescrito. Asimismo, brindar seguridad razonable que: 
- Los procesos son apropiados y están bien diseñados.

- La información financiera, de gestión y operativa significativa es precisa, confiable y oportuna.

- Las medidas de control y gestión de riesgos que la Gerencia ha implementado, son adecuadas y efectivas; y están funcionando de acuerdo a lo esperado.

- Las acciones de los colaboradores cumplen con las políticas, normas, procedimientos, leyes y regulaciones.

La unidad de auditoria interna reporta bimensualmente al comité de auditoría y este a su vez al consejo de administración, depende funcionalmente del comité y administrativamente de la gerencia general. Se integra por un gerente, cuatro supervisores y un auditor de agencias.

EI departamento tiene como objetivo agregar valor y mejorar las operaciones de la organización mediante la aplicación de un enfoque sistemático para evaluar y medir la eficacia de los procesos de gestión de riesgos, control y gobierno, que contribuyan al cumplimiento de objetivos de la institución. La actividad de auditoria interna se basa en las normas internacionales para el ejercicio profesional de auditoria interna y para evaluar el sistema de gestión integral de riesgos.

El director de auditoria interna realiza una planificación anual de auditoria interna en base a la matriz de riesgos global y los mapas de riesgo específicos por área funcional de la institución, en la que se incluye la evaluación del proceso de atención de reclamos.

\subsubsection{Metodología de Auditoría Basada en Riesgos}

El banco ha desarrollado una metodología de auditoría basada en riesgos la cual provee aseguramiento de que los riesgos se encuentran debidamente administrados por la compañía de acuerdo al nivel de tolerancia al riesgo establecido por la organización. Dicha metodología tiene los siguientes objetivos: 
- Aseguramiento de que los riesgos se encuentran adecuadamente identificados, evaluados y gestionados por las áreas de negocios.

- Aseguramiento que los controles son efectivos para mitigar los riesgos significativos para el cumplimiento de las políticas del banco.

Como se describió con anterioridad, el banco cuenta con políticas de control interno en base a gestión de riesgos en dónde cada unidad de negocio y las áreas que la conforman cuentan con matrices de riesgo identificadas por los mismos dueños del proceso las cuales son validadas por el área de Gestión de Riesgos, ello establecería el punto de partida para la labor del área de auditoría en la ejecución de sus actividades.

$\mathrm{Al}$ respecto, la metodología desarrollada por el banco define los siguientes pasos para el cumplimiento de las auditorías:

$\checkmark$ Plan de auditoría basada en riesgos: El plan ABR, fue aprobado por la SBS a fines del 2012, por lo que se incluye actividades anuales que han sido consideradas como procesos críticos los cuales no necesariamente están alineados a las definidas como obligatorias según la Res. SBS N 11699 2008. El plan de auditoría considera la estimación de recursos para el cumplimiento de las actividades antes descritas.

$\checkmark$ Pre auditoría: 5 semanas previas a la auditoría se envía un memorándum de intención de auditoría al dueño del proceso.

$\checkmark$ Planificación: Etapa en la que se realiza un entendimiento del proceso, identificación de riesgos y controles, pruebas de diseño de controles.

$\checkmark$ Trabajo de Campo: En base a el adecuado diseño de controles validado en la etapa anterior, se procede a efectuar el testeo de los mismos en base a la realización de un muestreo. En caso se identifiquen incidencias, se comenta con el dueño del proceso.

$\checkmark$ Reporte: Desarrollo de observaciones y recomendaciones. 


\subsection{Situaciones identificadas por la gerencia en proceso de mejora (sigpm)}

Son los eventos dentro del proceso que han sido identificados por la misma gerencia como oportunidad de mejora. Para poder calificar como SIGPM y no formar parte de las observaciones del reporte de auditoría debe cumplir con los siguientes criterios:

$\checkmark$ Plan de acción: Refiere cuando el negocio ha documentado formalmente planes de acción correctivos (incluidas acciones definidas y cronograma de actividades de levantamiento) para resolver la situación y mitigar el riesgo.

$\checkmark$ Recursos: Refiere cuando se ha aprobado la destinación de recursos para el levantamiento de la situación.

$\checkmark$ Fondos: Alineado a los recursos, debe contar con un presupuesto asignado ya que podría implicar cambios en procedimientos o sistemas.

$\checkmark$ Progreso: El plan de acción correctivo elaborado debe sustentarse con evidencia tangible del progreso de ejecución de actividades de levantamiento de situaciones.

\subsection{Plan anual de auditoría}

El Plan Anual de Trabajo de Auditoría Interna comprende las actividades a desarrollarse en el curso del año. El alcance de cada auditoria, incluirá procedimientos y pruebas de auditoria, acorde con los objetivos específicos establecidos para cada revisión; pudiéndose incluir, pruebas de soporte de tecnología de la información; teniendo acceso a toda información necesaria, sin limitación alguna que pueda afectar sus conclusiones; pudiendo solicitar a todos los niveles jerárquicos de la empresa, la documentación que considere pertinente para el eficiente y oportuno desempeño de sus funciones.

Asimismo, las actividades comprenderán las coordinaciones necesarias, tanto a nivel interno (Gerencias, Vicepresidencias, Comité de Auditoria y Directorio); así como a nivel externo (SBS, sociedad de auditoria externa y empresas clasificadoras de riesgo). 


\subsubsection{Planeación administrativa}

"Los auditores internos deben determinar los recursos adecuados y suficientes para lograr los objetivos del trabajo basándose en una evaluación de la naturaleza y complejidad de cada trabajo las restricciones de tiempo y recursos disponibles" (IAI, 2013, Norma 2230).

A continuación se detallan los recursos necesarios en la realización de la auditoria:

a. Recursos Humanos

Tabla 5.1 - Staff responsable del proceso de auditoría

\begin{tabular}{|l|l|l|}
\hline \multicolumn{1}{|c|}{ Puesto } & Nombre del Colaborador & Horas Hombre \\
\hline Gerente de Auditoria & Auditor 1 & $35 \mathrm{hrs}$ \\
\hline Supervisor de Auditoria & Auditor 2 & $85 \mathrm{hrs}$ \\
\hline Cosourcing de Auditoría & Alonso Rivero & $240 \mathrm{hrs}$ \\
\hline
\end{tabular}

Fuente: Elaboración Propia.

Tabla 5.2 - Estimación de horas del equipo de auditoría

\begin{tabular}{|l|c|c|c|c|}
\hline \multicolumn{1}{|c|}{ Actividad } & Gerente & Supervisor & Cosourcing & $\begin{array}{c}\text { Total } \\
\text { HH }\end{array}$ \\
\hline Pre auditoria & 5 & 10 & 20 & 35 \\
\hline Planificación del trabajo & 20 & 45 & 40 & 105 \\
\hline Ejecución del trabajo & 0 & 10 & 140 & 150 \\
\hline $\begin{array}{l}\text { Elaboración y presentación de } \\
\text { informe de auditoría }\end{array}$ & 5 & 10 & 20 & 35 \\
\hline Supervisión y seguimiento & 5 & 10 & 20 & 35 \\
\hline Total HH planificadas & 35 & 85 & 240 & 360 \\
\hline
\end{tabular}

Fuente: Elaboración Propia.

b. Recursos físicos

Una oficina y mobiliario y equipo ubicado en las instalaciones de la empresa.

c. Recursos Tecnológicos 
- Computadoras portátiles,

- 1 Impresora

- Fotocopiadora y

- Escáner.

d. Materiales

- 1 cartucho de impresora color negro,

- 1 cartucho de impresora de colores,

- 4 paquetes de papel bond tamaño carta y

- Lapiceros, (lápices, crayones y borradores).

\subsubsection{Programación de fecha de la auditoría}

La determinación de la fecha considera las nueve semanas programadas para la ejecución de las actividades de auditoría según el siguiente cronograma de actividades:

Tabla 5. 3 - Cronograma de actividades

\begin{tabular}{|c|c|c|c|c|c|c|c|c|c|}
\hline Actividad & 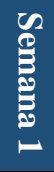 & 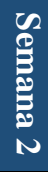 & 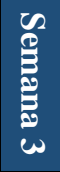 & 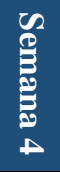 & 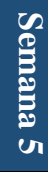 & 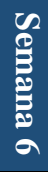 & 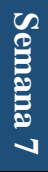 & 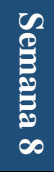 & 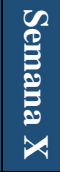 \\
\hline Pre auditoria & $\mathrm{x}$ & & 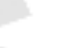 & & 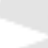 & & & & \\
\hline Planificación del trabajo & & $\mathrm{x}$ & $\mathrm{x}$ & $\mathrm{x}$ & & & & & \\
\hline Ejecución del trabajo & & & & & $\mathrm{x}$ & $\mathrm{x}$ & $\mathrm{x}$ & & \\
\hline $\begin{array}{l}\text { Elaboración y presentación de } \\
\text { informe de auditoría }\end{array}$ & & & & & & & & $\mathrm{x}$ & \\
\hline Supervisión y seguimiento $(*)$ & & & & & & & & & $\mathrm{X}$ \\
\hline
\end{tabular}

Nota: La supervisión y seguimiento según la metodología establecida constituye elaboración de procedimientos de validación los cuales estarán sujetos a la fecha de compromiso de levantamiento de observaciones que establezca el dueño del proceso.

Fuente: Elaboración Propia.

\subsection{Pre auditoría}

Es una etapa inicial de conocimiento del área o proceso a nivel general a evaluar en la institución, se debe buscar, seleccionar, comprender y analizar todo tipo de información de la forma en que se desarrollan sus actividades. En esta fase se establecen los objetivos preliminares, la naturaleza, oportunidad y alcance preliminar, pero estos 
pueden cambiar y dependen de la conclusión obtenida en la evaluación del control interno. Esta etapa considera puntualmente las siguientes actividades:

$\checkmark$ Identificación de dueños del proceso

$\checkmark$ Elaboración del requerimiento inicial de información

$\checkmark$ Elaboración del memorándum "Intención de auditoría" dirigido al dueño del proceso

$\checkmark$ Elaboración de la presentación de la reunión de inicio de auditoría

\subsubsection{Identificación de los dueños del proceso}

Se consultó el organigrama de la Vice-presidencia de Operaciones y Tecnología de la información a fin de identificar a los responsables del proceso de atención al cliente y su cargo, así tenemos:

- Vice presidente de Operaciones y Tecnología: Vice Presidente 1

- Gerente de atención al usuario: Gerente 1

- Supervisor de atención al cliente: Supervisor 1

- Sub- Gerente adjunto de asuntos regulatorios: Supervisor 2

\subsubsection{Elaboración del requerimiento inicial de información}

El requerimiento inicial contiene la información mínima requerida para la ejecución de las pruebas de auditoría para la etapa de planificación, en la cual se realizará una validación de la existencia y eficacia del diseño de los controles.

\subsubsection{Elaboración del memorándum "Intención de auditoría" dirigido al dueño del proceso.}

La comunicación de intención de auditoría debe enviarse entre 5 y 6 semanas previas al inicio de la etapa de planificación y debe estar dirigida a los principales miembros del equipo del proceso a auditar (Gerentes, Supervisores y Vicepresidente).

El contenido mínimo del documento, el cual puede enviarse vía e-mail o mediante memorándum interno, deberá indicar lo siguiente: 
- Proceso a auditar

- Objetivo de la auditoría

- Miembros del equipo de auditoría interna que participarán en el proceso de auditoría

- Fecha de inicio de actividades

- Canales de comunicación

- Requerimiento inicial adjunto

El modelo de la carta de inicio de actividades se encuentra adjunto en el ANEXO N 1 - Memorándum requerimiento de información e incluye el requerimiento de información.

\subsubsection{Elaboración de la presentación de la reunión de inicio de auditoría}

La reunión de inicio de la auditoría constituye una actividad primordial en el proceso de la auditoría ya que permite transmitir a los dueños del proceso de atención de reclamos los objetivos de la auditoría, alcance, fechas clave, miembros del equipo de Auditoría Interna y conceptos básicos referentes a la auditoría interna.

Así mismo, esta reunión pretende crear un clima de concientización acerca del propósito de la auditoría y su importancia en la posibilidad de obtener un valor añadido en el proceso a auditar. Esta reunión se llevará a cabo de preferencia en los primeros días de la etapa de planificación.

\subsection{Etapa de planeación}

En la etapa de planeación se deben tener claramente identificados todos los aspectos relevantes del área a auditar previo a cada evaluación como por ejemplo:

\section{Estructura organizacional}

$>$ Entendimiento del proceso

$>$ Base Regulatoria

$>$ Objetivos de la organización así como del área auditable

Riesgos críticos y controles clave

Antecedentes de hallazgos de auditorías anteriores (Internas y Externas) 
Debilidades en los controles identificados por el mismo dueño del proceso y que cuenten con un plan de acción.

Por otro lado, las normas del IAI establecen la necesidad de tener identificados los objetivos de cada trabajo a realizarse:

"Los auditores internos establecen los objetivos del trabajo con el fin de revisar los riesgos asociados con la actividad bajo revisión. Para los trabajos planificados, los objetivos provienen de la evaluación de riesgos”. (IAI, 2013 Norma 2210).

\subsubsection{Objetivo General}

Evaluar la efectividad del diseño y operatividad de los controles clave implementados por las áreas de negocio para asegurar el cumplimiento del marco regulatorio establecido en la circular $\mathrm{N}^{\circ}$ G-146-2009, las políticas internas del banco y el cumplimiento de los objetivos de la organización.

\subsubsection{Objetivos específicos}

Verificar que los controles, políticas y procedimientos establecidos en las distintas áreas sean eficientes y que permitan cumplir con los objetivos de los procesos.

$\checkmark$ Verificar la gestión de riesgos realizada por la administración para ayudar en el cumplimiento de los objetivos estratégicos de la institución.

$\checkmark$ Recomendar mejoras a los controles y a la gestión de riesgos establecidos por la administración, para agregar valor al proceso de atención de reclamos.

Mecanismos de comunicación y divulgación de información relacionada a la gestión de reclamos.

$\checkmark$ Gestión y disposición de Reclamos

$\checkmark$ Reportes Regulatorios. 


\subsubsection{Alcance de la auditoría}

$\checkmark$ Evaluar los controles, políticas y procedimientos establecidos en las distintas áreas para el cumplimiento de sus objetivos.

$\checkmark$ Evaluar la gestión de riesgos realizada por la administración en las áreas que intervienen en el proceso de atención de reclamos.

$\checkmark$ Emitir un informe con las respectivas recomendaciones en las cuales se ayude a mejorar el proceso de gestión de riesgos implementado en el proceso de atención de reclamos.

\subsubsection{Entendimiento del proceso de atención de reclamos}

La reunión de inicio de la auditoría contó con la participación del Vicepresidente de Operaciones y Tecnología, la supervisora de atención al cliente y la sub gerente de asuntos regulatorios. Se obtuvo una visión general del proceso de atención de reclamos lo que servirá como punto de partida para el inicio de la etapa de planificación.

No se obtuvo información acerca de la existencia de situaciones identificadas por la gerencia en proceso de mejora.

La metodología de auditoría basada en riesgos establece el uso de flujogramas de proceso para obtener un adecuado entendimiento de las actividades realizadas en la atención de reclamos, para ello, se efectúan reuniones individuales con los responsables de cada etapa del proceso a fin de obtener información de los riesgos y controles. A continuación se describen las ventajas del uso del flujograma:

$\checkmark$ Facilidad en el entendimiento y explicación de los procesos de manera rápida y eficiente.

$\checkmark$ Ayuda a los auditores a ver el proceso como un todo.

$\checkmark$ Es útil para discutir y aceptar actividades clave, riesgos y controles con la administración del negocio.

$\checkmark$ Gráficamente comunica actividades, procedimientos y controles y la secuencia en la que ocurren.

$\checkmark$ Puede utilizarse para identificar oportunidades de mejora en el diseño o el proceso. 
$\checkmark$ Identifica posible duplicidad de actividades en la que las tareas se repiten innecesariamente.

$\checkmark$ Provee un registro permanente del proceso.

$\checkmark$ Un procedimiento lógico y sistemático que puede ser revisado y evaluado por todos los auditores.

$\checkmark$ Menos dependiente del lenguaje a diferencia de una narrativa.

$\checkmark$ Demuestra los componentes de la entidad que están siendo considerados para la auditoría e incluye una referencia a los riesgos y controles clave.

El proceso de atención de reclamos se inicia con la apertura de los casos los cuales son registrados en un aplicativo llamado Eclipse. Los canales de recepción de reclamos se realizan a través de las agencias del banco y vía telefónica.

Los reclamos se registran en dicho aplicativo y son derivados al área pertinente dependiendo del tipo de evento, el cual puede ser uno de los siguientes:

Tabla 5.4 - Estadística de reclamos recibidos por el Banco

\begin{tabular}{|l|l|c|}
\hline \multicolumn{1}{|c|}{ Tipo de evento } & \multicolumn{1}{|c|}{$\begin{array}{c}\text { Área Responsable de } \\
\text { Atención }\end{array}$} & Proporción \\
\hline Quejas del servicio recibido & Canal de atención & $2 \%$ \\
\hline $\begin{array}{l}\text { Fallas del sistema informático que dificultan } \\
\text { operaciones y servicios }\end{array}$ & $\begin{array}{l}\text { Back office Customer } \\
\text { Service }\end{array}$ & $5 \%$ \\
\hline Cargos no reconocidos & Área de Controversias & $50 \%$ \\
\hline Promociones no reconocidas & $\begin{array}{l}\text { Back office Customer } \\
\text { Service }\end{array}$ & $3 \%$ \\
\hline $\begin{array}{l}\text { Cobros indebidos de intereses, comisiones, } \\
\text { gastos y tributos (tales como tarifas, seguros, }\end{array}$ & Área de Controversias & $30 \%$ \\
\hline ITF, entre otros cargos & Back office Customer & \\
\hline Transacciones no procesadas / mal realizadas & Service & $5 \%$ \\
\hline $\begin{array}{l}\text { Demoras o incumplimientos de envío de } \\
\text { correspondencia }\end{array}$ & $\begin{array}{l}\text { Back office Customer } \\
\text { Service }\end{array}$ & $2 \%$ \\
\hline Otros & $\begin{array}{l}\text { Back office Customer } \\
\text { Service }\end{array}$ & $3 \%$ \\
\hline TOTAL & $100 \%$ \\
\hline
\end{tabular}

Fuente: Elaboración Propia. 
Como se puede observar en la tabla anterior, la mayor parte de la concentración de reclamos se encuentra concentrada en la resolución de controversias por cargos no reconocidos. Este tipo de eventos es derivado al área de controversias, sin embargo, el área de atención al cliente es responsable de monitorear el cumplimiento del plazo regulatorio.

Cabe mencionar que el plazo máximo de atención según lo establecido en la circular SBS $N^{\circ}$ G-146-2009 es de 30 días y en caso de extensión debe notificarse oportunamente al cliente y siempre respetando el medio de comunicación pactado con el banco.

\section{Análisis del marco regulatorio}

De acuerdo a la revisión efectuada de la circular SBS N G-146-2009 se identificaron las siguientes actividades críticas de cumplimiento.

$\checkmark$ Contar con un sistema de atención al usuario

$\checkmark$ Contar procedimientos de atención de reclamos ordinarios y los provenientes de entidades gubernamentales.

$\checkmark$ Requerimiento del área de atención al usuario

$\checkmark$ Responsabilidad del encargado del proceso de atención al usuario.

$\checkmark$ Presentación de informes de gestión

$\checkmark$ Plazo máximo de atención de reclamos y el cómputo de los plazos.

$\checkmark$ Indicadores de Gestión.

$\checkmark$ Difusión de información de Reclamos recibidos a través de la página web

\section{Análisis de la información proporcionada por el área auditada}

Respecto a los documentos obtenidos del área auditada se pudo identificar la siguiente información relevante del proceso de atención de reclamos:

\section{a. Objetivos estratégicos del área de atención al usuario}

Los objetivos estratégicos se encuentran detallados en el plan anual de atención al usuario el cual fue proporcionado por el Gerente de Atención al cliente. Dicho plan contempla las actividades a realizarse durante el año 2014 así como los objetivos que deberán cumplirse en el año. 


\section{Objetivo General}

Obtener una gestión diferenciada en el servicio prestado a clientes mediante la implementación de la cultura de servicio en todos nuestros locales.

\section{Objetivos Específicos}

- Incentivar a los colaboradores a mejorar el trato que se les brinda a los clientes

- Capacitar a los colaboradores encargados de la atención al cliente

- Propiciar una división en el esquema se servicio para especializar a nuestros colaboradores de servicio y enfoque en la calidad de atención a los clientes.

- Crear posiciones de recepción y asesoramiento a nuestros clientes desde el primer contacto en nuestras agencias

- Contar con infraestructura adecuada para brindar el mejor servicio.

- Disminuir el nivel de insatisfacción del servicio brindado para evitar reclamos.

- Reducir los tiempos de atención de reclamos para ser competitivos a nivel local.

- Coordinar con las áreas de producto y operaciones las mejoras de procesos y planes de acción en base a los reclamos con mayor incidencia.

Cumplir con los requerimientos del regulador de una manera oportuna y eficaz.

\section{b. Roles y Responsabilidades}

A continuación se detalla las responsabilidades referentes al proceso de atención al usuario:

\section{Gerente de atención al usuario}

- Supervisar el correcto funcionamiento del sistema de atención al usuario.

- Elaborar el plan anual de capacitación

- Validar el envió de reporte trimestral de reclamos para la SBS

- Elaborar el plan anual de atención al usuario

- Capacitar a los colaboradores que participan del proceso de atención al usuario 
- Elaborar reportes mensuales de gestión

\section{Supervisor de atención al usuario}

- Velar por el cumplimiento del plan anual de capacitación

- Envió de reporte trimestral de reclamos para la SBS

- Elaborar reportes mensuales de gestión

- Supervisar el cumplimiento de plazos regulatorios de atención de reclamos

\section{Representantes de atención al usuario}

- Brindar la información necesaria a clientes respecto a los procedimientos de atención al usuario

- Ingresar los casos al aplicativo de atención al usuario al momento de la recepción del caso

- Compilar información soporte del reclamo en casos de consumos no reconocidos

- Envío de documentos al proveedor externo de digitalización

\section{c. Manuales de políticas y procedimientos}

El manual de políticas y procedimientos cuenta con los lineamientos generales del área de atención al usuario. Dicho documento ha sido aprobado en sesión de directorio y se encuentra disponible en la intranet del banco.

A manera de resumen, se presenta la información más significativa de dicho documento:

Sistema de registro de reclamos y solicitudes: Aplicativo Eclipse

Una vez registrado el reclamo se procede a imprimir un reporte del sistema el cual es firmado por el cliente. Para los reportes no presenciales dicho reporte es enviado al cliente por correo electrónico.

\section{Canales de atención al usuario:}

- Personal de Ventas 
- Agencias: Agendas de Atención al Usuario

- ATMs: Cajeros Automáticos

- Call center

- WEB: Página electrónica para consultas y transferencias

\section{Canales de respuesta al cliente:}

A través de los siguientes canales es suministrada la respuesta a las consultas y reclamos, solución que debe ser dada según las tiempos establecidos a cada tipología tiempo que no debe superar las 30 días según directriz de la SBS.

\section{Carta en físico}

- Correo electrónico

En los casos que este tiempo sea superado por la dificultad de la situación se debe mantener informado al cliente a través de comunicación telefónica o escrita, gestión Que debe ser registrada en el sistema administrador de reclamos, Eclipse.

En todos los casos que el requerimiento no proceda para el cliente, deberá enviarse la respuesta de forma escrita o por correo electrónico.

\section{Envió de reporte trimestral de reclamos para la SBS}

Dentro de los 15 días calendario de cada trimestre, Se envía las estadísticas de los reclamos presentados por los clientes a la SBS de manera impresa y por correo a contabilidad.

\section{Controles}

El equipo de Customer Service es responsable de realizar los siguientes controles:

- Verificar que el reporte de reclamos a la SBS haya sido enviado dentro de los primeros 15 días calendario de cada trimestre. 
- Verificar que los casos excedidos a 30 días cuenten con comunicación al cliente de la extensión del plazo.

- Quincenalmente Se realiza la revisión a través de Eclipse de los reclamos que están cercanos a las 30 días y si cuentan con la comunicación de la extensión del plazo de la atención de su reclamo, ya sea per calla física, vía correo electrónico o por teléfono.

- Verificar el acuse del envió para los reclamos contestados por Carta física.

- Quincenalmente se realiza la revisión a través de la ruta de archivos compartidos una muestra aleatoria de las imágenes de los acuses de entrega de las cartas de reclamos.

- Verificar, para los reclamos no presenciares en donde el cliente consigne un correo electrónico, Que se realice el envio de la hoja de reclamación por ese medio.

- Quincenalmente se realiza la revisión de Una muestra aleatoria de reclamos no presenciales y se solicita al call center que envié las evidencias del envió del reporte del reclamo al correo electrónico indicado por el cliente.

- De detectarse algún incumplimiento en alguno de los procesos mencionados se reportara al área responsable para que se ejecute la medida correctiva correspondiente.

\section{d. Matriz de Riesgo elaborada por el área de atención de reclamos}

De los riesgos identificados por el área de atención al cliente, relacionados al proceso de atención de reclamos, se obtuvieron los siguientes:

Tabla 5.5 - Matriz de Riesgos del proceso de atención de reclamos proporcionada por el negocio.

\begin{tabular}{|c|c|c|c|c|c|c|}
\hline $\mathbf{N}$ & RIESGO & $\begin{array}{l}\text { PROBA- } \\
\text { BILIDAD }\end{array}$ & IMPACTO & RIESGO & \begin{tabular}{|l|} 
IMPACTO EN \\
EL NEGOCIO \\
\end{tabular} & $\begin{array}{l}\text { ACTIVIDADES } \\
\text { DE CONTROL }\end{array}$ \\
\hline 1 & $\begin{array}{lr}\text { Entregar ron } & \text { con } \\
\text { errores y/o atraso } \\
\text { los Anexos } & \text { de } \\
\text { Reclamos de de } & \text { Clientes a la SBS. }\end{array}$ & Medio & Alto & Medio & $\begin{array}{l}\text { Observación, } \\
\text { amonestación, } \\
\text { sanción por parte } \\
\text { de la SBS. }\end{array}$ & $\begin{array}{l}\text { El supervisor de } \\
\text { atención al cliente } \\
\text { prepara los reportes } \\
\text { trimestrales y los } \\
\text { envía al área de } \\
\text { contabilidad para } \\
\text { su presentación a la } \\
\text { SBS. }\end{array}$ \\
\hline
\end{tabular}




\begin{tabular}{|c|c|c|c|c|c|c|}
\hline 2 & $\begin{array}{l}\text { Incumplimiento } \\
\text { del plazo de } 30 \\
\text { días para la } \\
\text { atención de los } \\
\text { reclamos } \\
\text { clientes }\end{array}$ & Medio & Alto & Medio & $\begin{array}{l}\text { Observación, } \\
\text { amonestación, } \\
\text { sanción por parte } \\
\text { de la SBS. }\end{array}$ & $\begin{array}{l}\text { El analista de } \\
\text { atención al usuario } \\
\text { emite un reporte } \\
\text { diario ro del } \\
\text { aplicativo Eclipse y } \\
\text { filtra los casos con } \\
\text { antigüedad cercana } \\
\text { a los } 25 \text { días. } \\
\text { Analiza que estén } \\
\text { por ser atendidos o } \\
\text { que se les haya } \\
\text { enviado carta de } \\
\text { extensión. }\end{array}$ \\
\hline
\end{tabular}

Fuente: Elaboración Propia.

Como se puede observar en la matriz anterior, el área de atención al cliente ha identificado únicamente dos riesgos críticos, los cuales tienen un impacto significativo en el negocio.

\subsubsection{Identificación del universo de riesgos}

"Los auditores internos deben realizar una evaluación preliminar de los riesgos relevantes para la actividad bajo revisión. Los objetivos del trabajo deben reflejar los resultados de esta evaluación. (IAI. Consejo para la práctica $\mathrm{N}^{\circ} 2310-\mathrm{A} 1$ )”.

Los auditores internos tienen en cuenta la evaluación de riesgos realizada por la dirección que sea relevante para la actividad bajo revisión. El auditor interno también contempla lo siguiente:

La fiabilidad de la evaluación de riesgos realizada por la dirección.

El proceso que sigue la dirección para vigilar, informar y resolver asuntos de riesgos y control.

$\checkmark$ Los informes de la dirección sobre eventos que hayan excedido los límites de la organización respecto de la aceptación de riesgos y la respuesta de la dirección a aquellos informes.

$\checkmark$ Los riesgos en actividades relacionadas que sean relevantes para la actividad bajo revisión. (IAI, 2013 Consejo para la práctica N²310-A1).

Tomando en consideración los riesgos identificados por el negocio en la sección anterior, el análisis del marco regulatorio y del proceso, se identificaron eventos significativos que su inadecuado funcionamiento puede representar un impacto negativo para el banco, por ello se amplió la cantidad de riesgos en base al criterio del auditor. 
En lo que respecta a la redacción del riesgo, en base a la metodología de auditoría basada en riesgos, debe contemplarse lo siguiente:

\author{
Evento \\ $\checkmark$ Causa del evento \\ $\checkmark$ Consecuencia
}

Por lo tanto, obtuvimos los siguientes riesgos:

Tabla 5.6- Universo de riesgos identificados por auditoría interna.

\begin{tabular}{|c|c|c|c|c|}
\hline $\mathbf{N}$ & RIESGO & PROBABILIDAD & IMPACTO & RIESGO \\
\hline 1 & $\begin{array}{l}\text { Estructura } \\
\text { inapropiada. Falta de segregación de } \\
\text { funciones y entrenamiento } \\
\text { inapropiado puede resultar en manejo } \\
\text { inadecuado de las quejas del cliente y } \\
\text { exposición del banco a sanciones del } \\
\text { regulador. }\end{array}$ & Medio & Alto & Alto \\
\hline 2 & $\begin{array}{l}\text { Difusión inapropiada de la } \\
\text { administración de quejas y procesos } \\
\text { de presentación limitan el nivel de } \\
\text { información disponible para los } \\
\text { clientes y expone al banco a } \\
\text { sanciones del regulador. }\end{array}$ & Medio & Alto & Alto \\
\hline 3 & $\begin{array}{l}\text { Procesos inapropiados para registrar } \\
\text { las quejas de clientes expone al } \\
\text { banco a sanciones del regulador. }\end{array}$ & Medio & Alto & Alto \\
\hline 4 & $\begin{array}{l}\text { Administración inapropiada y tardía } \\
\text { de quejas de clientes expone al banco } \\
\text { a sanciones del regulador. }\end{array}$ & Medio & Alto & Alto \\
\hline 5 & $\begin{array}{l}\text { Inapropiada administración de los } \\
\text { archivos de quejas de los clientes } \\
\text { expone al banco a sanciones del } \\
\text { regulador. }\end{array}$ & Medio & Alto & Alto \\
\hline 6 & $\begin{array}{l}\text { Administración inapropiada y } \\
\text { atrasada de los reportes de quejas } \\
\text { trimestrales regulatorios expone al } \\
\text { banco a sanciones del regulador. }\end{array}$ & Medio & Alto & Alto \\
\hline
\end{tabular}




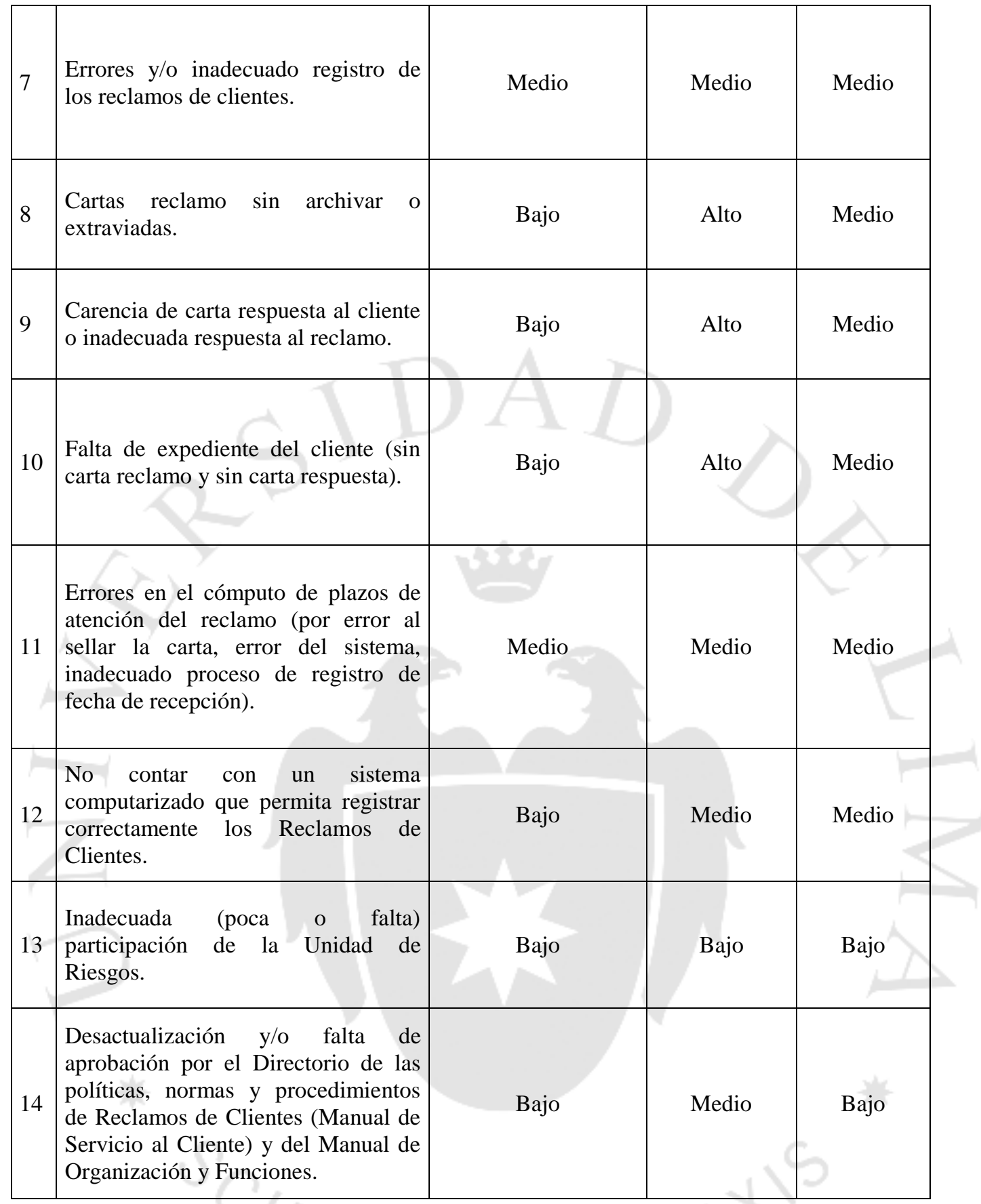

Fuente: Elaboración Propia.

Se observa en la tabla anterior que se han identificado 14 riesgos a los cuales se les ha calificado según su nivel de criticidad.

\subsubsection{Identificación de Riesgos críticos}

De acuerdo al análisis realizado por el área de auditoría interna, los riesgos calificados como altos contemplan actividades que su inadecuado funcionamiento puede conllevar a sanciones del regulador y pérdidas económicas para la compañía. Si bien estas 
actividades no se encuentran consideradas en la matriz de riesgo del negocio se encuentran documentadas en el manual de procedimientos de atención al usuario.

Así mismo, estos riesgos críticos, o Riesgos clave se encuentran alineados al cumplimiento de los objetivos estratégicos del área de atención de reclamos, es decir, su omisión o falta de mitigación conllevaría no sólo a sanciones por parte del regulador sino a impactar la reputación del banco.

A continuación se detallan los riesgos clave y su impacto en los objetivos estratégicos del área de atención de reclamos.

Tabla 5.7 - Matriz de riesgos calificados como críticos.

\begin{tabular}{|c|c|c|c|c|c|}
\hline $\mathbf{N}$ & RIESGO & $\begin{array}{l}\text { PROBA- } \\
\text { BILIDAD }\end{array}$ & IMPACTO & RIESGO & \begin{tabular}{|l} 
OBJETIVO ESTRATEGICO \\
INVOLUCRADO
\end{tabular} \\
\hline 1 & $\begin{array}{l}\text { Estructura organizacional } \\
\text { inapropiada. Falta de } \\
\text { segregación de funciones } \\
\text { y entrenamiento } \\
\text { inapropiado puede } \\
\text { resultar en manejo } \\
\text { inadecuado de las quejas } \\
\text { del cliente y exposición } \\
\text { del banco a sanciones del } \\
\text { regulador. }\end{array}$ & Medio & Alto & Alto & $\begin{array}{l}\text { - Incentivar a los colaboradores a } \\
\text { mejorar el trato que se les brinda a } \\
\text { los } \\
\text { - Capacitar a los colaboradores } \\
\text { encargados de la atención al } \\
\text { cliente } \\
\text { - Propiciar una división en el } \\
\text { esquema se servicio para } \\
\text { especializar } \\
\text { colaboradores de servicio y } \\
\text { enfoque en la calidad de atención } \\
\text { a los clientes. }\end{array}$ \\
\hline 2 & $\begin{array}{l}\text { Difusión inapropiada de la } \\
\text { administración de quejas } \\
\text { y procesos de } \\
\text { presentación limitan el } \\
\text { nivel de información } \\
\text { disponible para los } \\
\text { clientes y expone al banco } \\
\text { a sanciones del regulador. }\end{array}$ & Medio & Alto & Alto & $\begin{array}{l}\text { - Incentivar a los colaboradores a } \\
\text { mejorar el trato que se les brinda a } \\
\text { los clientes. } \\
\text { - Crear posiciones de recepción y } \\
\text { asesoramiento a nuestros clientes } \\
\text { desde el primer contacto en } \\
\text { nuestras agencias }\end{array}$ \\
\hline 3 & $\begin{array}{l}\text { Procesos inapropiados } \\
\text { para registrar las quejas } \\
\text { de clientes expone al } \\
\text { banco a sanciones del } \\
\text { regulador. }\end{array}$ & Medio & Alto & Alto & $\begin{array}{l}\text { - Contar con infraestructura } \\
\text { adecuada para brindar el mejor } \\
\text { servicio. }\end{array}$ \\
\hline 4 & $\begin{array}{l}\text { Administración } \\
\text { inapropiada y tardía de } \\
\text { quejas de clientes expone } \\
\text { al banco a sanciones del } \\
\text { regulador. }\end{array}$ & Medio & Alto & Alto & $\begin{array}{l}\text { - Reducir los tiempos de atención } \\
\text { de reclamos para ser competitivos } \\
\text { a nivel local. }\end{array}$ \\
\hline 5 & $\begin{array}{l}\text { Inapropiada } \\
\text { administración de los } \\
\text { archivos de quejas de los } \\
\text { clientes expone al banco a }\end{array}$ & Medio & Alto & Alto & $\begin{array}{l}\text { - Contar con infraestructura } \\
\text { adecuada para brindar el mejor } \\
\text { servicio. }\end{array}$ \\
\hline
\end{tabular}




\begin{tabular}{|l|l|l|l|l|l|}
\hline N & $\begin{array}{l}\text { RIESGO } \\
\text { sanciones del regulador. } \\
\text { BILIDAD }\end{array}$ & IMPACTO & RIESGO & $\begin{array}{l}\text { OBJETIVO ESTRATEGICO } \\
\text { INVOLUCRADO }\end{array}$ \\
\hline 6 & $\begin{array}{l}\text { Administración } \\
\text { inapropiada y atrasada de } \\
\text { los reportes de quejas } \\
\text { trimestrales regulatorios } \\
\text { expone al banco a } \\
\text { sanciones del regulador. }\end{array}$ & Medio & Alto & Alto & $\begin{array}{l}\text { - Cumplir con los requerimientos } \\
\text { regulador de una manera } \\
\text { oportuna y eficaz. }\end{array}$ \\
\hline
\end{tabular}

Fuente: Elaboración Propia.

\subsubsection{Elaboración del Flujograma de proceso}

Como se mencionó con anterioridad, el banco ha establecido dentro de su metodología el uso de los flujogramas de proceso para el mapeo de las principales actividades que se realizan en la atención de reclamos. En tal sentido, la información necesaria para su elaboración es obtenida a través de las entrevistas con los responsables del proceso y la revisión de los manuales de políticas y procedimientos.

Previo a la elaboración del flujograma de proceso es necesario reunirse con el dueño del proceso a fin de obtener información de las actividades que se realizan para el cumplimiento de objetivos del área.

En base a los datos obtenidos en la reunión, la cual contó con la presencia del Gerente de Atención al Usuario y el Supervisor de Atención al Usuario se pudo elaborar el flujograma del proceso de atención de reclamos el cual se puede visualizar en el ANEXO N ${ }^{\circ} 2$ - Flujograma del proceso de atención de reclamos.

Dicho flujograma describe el proceso de atención de reclamos especificando roles y responsabilidades así como la ubicación de los riesgos y sus respectivos controles.

\subsubsection{Identificación de controles clave asociados}

La reunión de entendimiento del proceso, no sólo permitió identificar los riesgos críticos o clave descritos en la sección anterior sino a su vez enlazarlos a los controles 
clave que permiten mitigarlos con lo cual se validaría que el banco cuenta con una adecuada política de gestión de riesgos.

Así mismo, se pudo observar en el flujograma del proceso que las actividades de control descritas se ejecutan a fin de mitigar los riesgos, por lo tanto el paso siguiente es alinear los controles clave a los riesgos identificados para establecer el punto de partida en las pruebas de diseño.

A partir de los riesgos críticos relevantes seleccionados para ser evaluados durante la auditoría, se identificaron y seleccionaron los controles claves del proceso que permiten minimizar el nivel de exposición del riesgo. En esta etapa también se identifican las principales causas de riesgo asociadas a las actividades de control que realizan durante todo el proceso para mitigar su posible materialización. Estas actividades de control permiten que la gerencia logre una seguridad razonable en la gestión y administración de los riesgos asociados a su actividad, mediante un sistema de control interno que ayude a prevenir oportunamente la posible materialización de los riesgos inherentes asociados al negocio, así como la disminución del posible impacto para el logro de los objetivos de la entidad.

Tabla 5.8 - Matriz de Riesgos y Controles Clave

\begin{tabular}{|c|c|c|}
\hline RIESGO & $\begin{array}{c}\text { OBJETIVO } \\
\text { ESTRATEGICO } \\
\text { INVOLUCRADO }\end{array}$ & CONTROL CLAVE \\
\hline \multirow{2}{*}{$\begin{array}{l}\text { 1. Estructura organizacional } \\
\text { inapropiada. Falta de } \\
\text { segregación de funciones y } \\
\text { entrenamiento inapropiado } \\
\text { puede resultar en manejo } \\
\text { inadecuado de las quejas del } \\
\text { cliente y exposición del banco a } \\
\text { sanciones del regulador. }\end{array}$} & \multirow{2}{*}{$\begin{array}{l}\text { - Incentivar a los } \\
\text { colaboradores a mejorar el } \\
\text { trato que se les brinda a los } \\
\text { clientes } \\
\text { - Capacitar a los } \\
\text { colaboradores encargados } \\
\text { de la atención al cliente } \\
\text { - Propiciar una división en } \\
\text { el esquema se servicio para } \\
\text { especializar a nuestros } \\
\text { colaboradores de servicio y } \\
\text { enfoque en la calidad de } \\
\text { atención a los clientes. }\end{array}$} & $\begin{array}{l}\text { 1.1 Anualmente, el Gerente de atención } \\
\text { de reclamos actualiza el manual de } \\
\text { políticas y procedimientos mediante la } \\
\text { inclusión de los cambios realizados en el } \\
\text { año y lo envía para su aprobación en } \\
\text { sesión de directorio. El control se } \\
\text { encuentra evidenciado a través del acta } \\
\text { de sesión de directorio. }\end{array}$ \\
\hline & & $\begin{array}{l}\text { 1.2 Anualmente, el Gerente de atención } \\
\text { al cliente elabora el plan anual de } \\
\text { capacitación en base a la cantidad de } \\
\text { trabajadores y un cronograma de } \\
\text { sesiones de entrenamiento. El control se } \\
\text { encuentra evidenciado a través de dicho } \\
\text { plan y su aprobación mediante sesión de } \\
\text { directorio. }\end{array}$ \\
\hline
\end{tabular}




\begin{tabular}{|c|c|c|}
\hline RIESGO & $\begin{array}{c}\text { OBJETIVO } \\
\text { ESTRATEGICO } \\
\text { INVOLUCRADO } \\
\end{array}$ & CONTROL CLAVE \\
\hline & & $\begin{array}{l}\text { 1.3 En caso de reemplazo del oficial de } \\
\text { atención al usuario, el directorio designa } \\
\text { a un nuevo responsable mediante sesión. } \\
\text { Este control es evidenciado a través de } \\
\text { las actas de directorio y la posterior } \\
\text { comunicación a la SBS. }\end{array}$ \\
\hline $\begin{array}{l}\text { 2. Difusión inapropiada de la } \\
\text { administración de quejas y } \\
\text { procesos de presentación } \\
\text { limitan el nivel de información } \\
\text { disponible para los clientes y } \\
\text { expone al banco a sanciones del } \\
\text { regulador. }\end{array}$ & $\begin{array}{l}\text { - Incentivar a los } \\
\text { colaboradores a mejorar el } \\
\text { trato que se les brinda a los } \\
\text { clientes. } \\
\text { - Crear posiciones de } \\
\text { recepción y asesoramiento a } \\
\text { nuestros clientes desde el } \\
\text { primer contacto en nuestras } \\
\text { agencias } \\
\end{array}$ & $\begin{array}{l}\text { 2.1 Mensualmente, el supervisor de } \\
\text { atención al usuario verifica la } \\
\text { disponibilidad de folletería informativa } \\
\text { del proceso de atención de reclamos en } \\
\text { agencias y en la página web. Este } \\
\text { control se encuentra evidenciado a } \\
\text { través del checklist de revisión } \\
\text { documentaria el cual es firmado por el } \\
\text { gerente de tienda y el supervisor. }\end{array}$ \\
\hline $\begin{array}{l}\text { 3. Procesos inapropiados para } \\
\text { registrar las quejas de clientes } \\
\text { expone al banco a sanciones del } \\
\text { regulador. }\end{array}$ & $\begin{array}{l}\text { - Contar con infraestructura } \\
\text { adecuada para brindar el } \\
\text { mejor servicio. }\end{array}$ & $\begin{array}{l}\text { 3.1 En cada reclamo recibido, el agente } \\
\text { de agencia o call center registra la } \\
\text { información del cliente y el reclamo en } \\
\text { el sistema de reclamos Eclipse de } \\
\text { acuerdo a los requerimientos mínimos } \\
\text { de información establecidos en el } \\
\text { manual de atención al usuario. Este } \\
\text { control se encuentra evidenciado a } \\
\text { través de los reportes emitidos por el } \\
\text { sistema los cuales son firmados por el } \\
\text { cliente o enviados a su correo. }\end{array}$ \\
\hline $\begin{array}{l}\text { 4. Administración inapropiada y } \\
\text { tardía de quejas de clientes } \\
\text { expone al banco a sanciones del } \\
\text { regulador. }\end{array}$ & $\begin{array}{l}\text { - Reducir los tiempos de } \\
\text { atención de reclamos para } \\
\text { ser competitivos a nivel } \\
\text { local. }\end{array}$ & $\begin{array}{l}\text { 4.1 Diariamente, el analista backoffice } \\
\text { de servicio al cliente monitorea los } \\
\text { plazos de atención de reclamos mediante } \\
\text { reportes diarios de rastreo de casos } \\
\text { emitido por el sistema eclipse. Este } \\
\text { control se encuentra evidenciado a } \\
\text { través del cuadro de control de } \\
\text { anticuamiento. }\end{array}$ \\
\hline $\begin{array}{l}\text { 5. Inapropiada administración } \\
\text { de los archivos de quejas de los } \\
\text { clientes expone al banco a } \\
\text { sanciones del regulador. }\end{array}$ & $\begin{array}{l}\text { - Contar con infraestructura } \\
\text { adecuada para brindar el } \\
\text { mejor servicio. }\end{array}$ & $\begin{array}{l}\text { 5.1 Diariamente, el analista de } \\
\text { backoffice de servicio al cliente } \\
\text { almacena los registros de reclamos en un } \\
\text { sistema repositorio de imágenes del } \\
\text { banco. El supervisor de servicios al } \\
\text { consumidor ejecuta la validación } \\
\text { semanal del sistema de imágenes } \\
\text { mediante un muestreo en el cual verifica } \\
\text { la integridad de los documentos. Este } \\
\text { control se encuentra evidenciado a } \\
\text { través de su matriz de revisión. }\end{array}$ \\
\hline
\end{tabular}




\begin{tabular}{|l|l|l|}
\hline \multicolumn{1}{|c|}{ RIESGO } & \multicolumn{1}{|c|}{$\begin{array}{c}\text { OBJETIVO } \\
\text { ESTRATEGICO } \\
\text { INVOLUCRADO }\end{array}$} & \multicolumn{1}{c|}{ CONTROL CLAVE } \\
\hline $\begin{array}{l}\text { 6. Administración inapropiada y } \\
\text { atrasada de los reportes de } \\
\text { quejas trimestrales regulatorios } \\
\text { expone al banco a sanciones del } \\
\text { regulador. }\end{array}$ & $\begin{array}{l}\text { - Cumplir con los } \\
\text { requerimientos del } \\
\text { regulador de una manera } \\
\text { oportuna y eficaz. }\end{array}$ & $\begin{array}{l}\text { 6.1 Trimestralmente, el supervisor de } \\
\text { atención al usuario elabora reportes de } \\
\text { gestión estadístico de los reclamos } \\
\text { recibidos en el periodo y envía al área de } \\
\text { contabilidad para que lo remitan a la } \\
\text { SBS. Este control se encuentra } \\
\text { evidenciado a través de los reportes } \\
\text { trimestrales en comité de gerencia de } \\
\text { atención de reclamos y el archivo de } \\
\text { envío a la SBS. }\end{array}$ \\
\hline
\end{tabular}

Fuente: Elaboración Propia.

\subsubsection{Pruebas de diseño de controles (PDC)}

El diseño de las actividades de control permite asegurar el logro de los objetivos estratégicos de la entidad. El auditor evalúa la efectividad aplicando diferentes técnicas y pruebas de auditoría para validar la existencia, documentación y cumplimiento de los objetivos del control que normalmente son definidos para prevenir y detectar posibles errores o fraudes. (Nahun Freundt, 2012).

Las opciones de respuesta para las preguntas de las variables de este factor son "Sí" o "No" cuando se evalúa el adecuado diseño de los controles. Por lo tanto, el auditor debe considerar los siguientes criterios:

$\checkmark$ Que control se está ejecutando (¿Es el tipo de control identificado, apropiado para conseguir el objetivo de mitigar el riesgo?

$\checkmark$ Quien ejecuta el control (¿La persona que ejecuta el control posee las competencias apropiadas para su ejecución y si esta persona tiene funciones incompatibles)

$\checkmark$ Cuando el control se ejecuta (¿El control ejecutado se realiza con la frecuencia adecuada? ¿En qué etapa del proceso?

$\checkmark$ Donde se evidencia el control (¿Se documenta?

$\checkmark$ Cómo el control es ejecutado (¿Existen procedimientos específicos establecidos para la ejecución del control? 
Por otro lado, el banco ha establecido un formato de evaluación de controles PCD (Prueba de diseño de controles) el cual se alinea a los criterios antes descritos y pretende responder las 5 preguntas.

\section{- ¿Es este el control adecuado para mitigar el riesgo?}

Refiere a que la ausencia de este control podría exponer al banco a un riesgo crítico.

- ¿El control es ejecutado por la persona adecuada en el nivel jerárquico apropiado?

El ejecutor del control es independiente del proceso o sub proceso auditado, es decir que existe una adecuada segregación de funciones.

- ¿El control se ejecuta en la etapa adecuada del proceso?

Dependiendo si es un control preventivo o detectivo, debe realizarse previo o posterior a la actividad generadora del riesgo.

\section{- ¿El control es sostenible?}

Refiere a si el control podría seguir ejecutándose a pesar de que las operaciones o número de transacciones se incremente y si es adecuadamente cubierto con el perfil de personal idóneo.

\section{- ¿El control se encuentra evidenciado?}

Refiere si el ejecutor del control documenta el desenvolvimiento del control.

Las técnicas de auditoría para efectuar las pruebas pueden ser generalmente categorizadas entre pruebas de controles y pruebas sustantivas.

Las pruebas de Controles son pruebas que aseguran que los procedimientos o mecanismos se adhieren a los requerimientos regulatorios, prácticas de la industria, 
políticas corporativas y las expectativas de los controles. En tal sentido, la metodología establece el uso de las siguientes pruebas:

Inspección: Útil cuando hay documentos (digitales o físicos) como evidencia de la operación del control.

> Reproceso: Un auditor efectúa un re proceso del control actual y compara sus resultados con los resultados obtenidos por el operador del control.

> Observación: Consiste en observar la operación de un control. Es más útil cuando los controles no cuentan con evidencia de los mismos.

Indagación: Involucra entrevistas detalladas con los dueños del proceso y controles u otros individuos con lo cual se puede saber si el procedimiento se encuentra operando.

Las pruebas de controles son más efectivas cuando se combinan las técnicas descritas en el párrafo anterior. La observación e indagación no son tan útiles para proveer de evidencia suficiente que soporte la conclusión de la efectividad de la operación del control pero pueden servir de evidencia corroborativa.

Las pruebas sustantivas se emplean como complemento a la prueba del funcionamiento de los controles.

Las pruebas sustantivas se usan cuando se requiere un detalle adicional de la revisión para validad la integridad y validez de la data.

$>$ Generalmente las pruebas están diseñadas para detectar observaciones materiales en un punto específico de tiempo.

Ejemplos de pruebas sustantivas:

- Inventarios físicos que prueban los registros.

- Revisar documentación soporte como facturas que confirmen que las ventas ocurrieron.

- Coordinar con proveedores para confirmar mediante cartas los saldos pendientes de pago.

- Realizar indagación de los saldos de clientes a fin de evidenciar que los ingresos se valuaron correctamente. 


\section{Análisis de brechas con la normativa vigente}

Como se explicó con anterioridad, los riesgos críticos identificados además de generar un impacto negativo en el banco por pérdidas económicas, también se encuentran regulados en la Circular SBS G 146-2009.

Por tal motivo, el paso inicial es alinear cada artículo de la norma a los riesgos ya identificados. Posteriormente, en base a la documentación proporcionada por el área de atención al cliente, verificar si existe alguna brecha en el cumplimiento de los citados artículos, el resultado de tal revisión fue el siguiente:

Tabla 5.9 - Análisis de brechas de la circular SBS G 146-2009.

\begin{tabular}{|c|c|c|c|c|}
\hline Referencia Norma & Descripción & $\begin{array}{l}\text { Evidencia } \\
\text { Área de } \\
\text { atención al } \\
\text { usuario }\end{array}$ & $\begin{array}{l}\text { Análisis } \\
\text { Auditoría } \\
\text { Interna }\end{array}$ & $\begin{array}{c}\text { Riesgo } \\
\text { asociado }\end{array}$ \\
\hline \multirow{2}{*}{$\begin{array}{l}\text { Artículo } 3 \text { - } \\
\text { Atención de } \\
\text { Consultas }\end{array}$} & $\begin{array}{l}\text { 3.1 Las empresas supervisadas } \\
\text { deberán contar con manuales de } \\
\text { atención de consultas donde } \\
\text { establezcan los procedimientos y } \\
\text { plazos. Dichos manuales se } \\
\text { encontrarán a disposición de la } \\
\text { Superintendencia cuando ésta los } \\
\text { requiera. }\end{array}$ & $\begin{array}{l}\text { Manual de } \\
\text { atención de } \\
\text { Reclamos }\end{array}$ & Cumple & \multirow{2}{*}{$\begin{array}{l}\text { 1. Estructura } \\
\text { organizacional } \\
\text { inapropiada. } \\
\text { Falta de } \\
\text { segregación de } \\
\text { funciones y } \\
\text { entrenamiento } \\
\text { inapropiado } \\
\text { puede resultar } \\
\text { en manejo } \\
\text { inadecuado de } \\
\text { las quejas del } \\
\text { cliente y } \\
\text { exposición del } \\
\text { banco a } \\
\text { sanciones del } \\
\text { regulador. }\end{array}$} \\
\hline & $\begin{array}{l}\text { 3.2 Las empresas supervisadas } \\
\text { deberán contar con personal } \\
\text { capacitado y especializado en la } \\
\text { atención a los usuarios con la } \\
\text { finalidad de atender sus consultas; } \\
\text { dicho personal deberá estar } \\
\text { debidamente identificado, con sus } \\
\text { nombres y apellidos. }\end{array}$ & No aplica & Cumple & \\
\hline $\begin{array}{l}\text { Artículo } 4 \text { - } \\
\text { Requerimientos de } \\
\text { información de } \\
\text { entidades } \\
\text { gubernamentales. }\end{array}$ & $\begin{array}{l}\text { Las empresas supervisadas deberán } \\
\text { contar con manuales para la atención } \\
\text { de los requerimientos de información } \\
\text { efectuados por las entidades } \\
\text { gubernamentales, tales como, la } \\
\text { Superintendencia, el Congreso de la } \\
\text { República, el INDECOPI, la } \\
\text { Defensoría del Pueblo, u otros } \\
\text { similares, en virtud de consultas, } \\
\text { reclamos y denuncias que éstas } \\
\text { hubieran recibido de usuarios. }\end{array}$ & \multicolumn{3}{|c|}{ No incluido en el alcance } \\
\hline
\end{tabular}




\begin{tabular}{|c|c|c|c|c|}
\hline Referencia Norma & Descripción & $\begin{array}{l}\text { Evidencia } \\
\text { Área de } \\
\text { atención al } \\
\text { usuario }\end{array}$ & $\begin{array}{l}\text { Análisis } \\
\text { Auditoría } \\
\text { Interna }\end{array}$ & $\begin{array}{l}\text { Riesgo } \\
\text { asociado }\end{array}$ \\
\hline \multirow{4}{*}{$\begin{array}{l}\text { Artículo } 5 \text { - } \\
\text { Sistema de } \\
\text { Atención de } \\
\text { Reclamos }\end{array}$} & $\begin{array}{l}\text { 5.1 Las empresas supervisadas } \\
\text { deberán contar con un adecuado } \\
\text { sistema de atención de reclamos, } \\
\text { estableciendo manuales de } \\
\text { procedimientos para el registro, } \\
\text { seguimiento y atención de los } \\
\text { mismos, incluyendo los requisitos de } \\
\text { presentación, los diversos canales de } \\
\text { recepción, los plazos internos de } \\
\text { atención, la interacción con otras } \\
\text { áreas, entre otros aspectos. }\end{array}$ & $\begin{array}{l}\text { Manual de } \\
\text { atención de } \\
\text { Reclamos / } \\
\text { Instructivo } \\
\text { del sistema } \\
\text { Eclipse }\end{array}$ & Cumple & \multirow{4}{*}{$\begin{array}{l}\text { 1. Estructura } \\
\text { organizacional } \\
\text { inapropiada. } \\
\text { Falta de } \\
\text { segregación de } \\
\text { funciones y } \\
\text { entrenamiento } \\
\text { inapropiado } \\
\text { puede resultar } \\
\text { en manejo } \\
\text { inadecuado de } \\
\text { las quejas del } \\
\text { cliente y } \\
\text { exposición del } \\
\text { banco a } \\
\text { sanciones del } \\
\text { regulador. }\end{array}$} \\
\hline & $\begin{array}{l}\text { 5.2 Las empresas supervisadas } \\
\text { deberán elaborar un plan anual de } \\
\text { capacitación del personal encargado } \\
\text { de la atención de reclamos y/o } \\
\text { consultas. }\end{array}$ & $\begin{array}{l}\text { Plan Anual de } \\
\text { capacitación }\end{array}$ & Cumple & \\
\hline & $\begin{array}{l}\text { 5.3 Las empresas supervisadas } \\
\text { podrán establecer diferentes canales } \\
\text { de recepción de los reclamos de los } \\
\text { usuarios,(vía telefónica, correo } \\
\text { electrónico, fax, página Web, entre } \\
\text { otros). }\end{array}$ & $\begin{array}{l}\text { Página web, } \\
\text { Call center }\end{array}$ & Cumple & \\
\hline & $\begin{array}{l}\text { 5.4 Las empresas supervisadas } \\
\text { deberán registrar todos los reclamos } \\
\text { que formulen los usuarios en un } \\
\text { soporte informático que permita un } \\
\text { adecuado seguimiento de la atención } \\
\text { brindada a los mismos, } \\
\text { independientemente del canal o } \\
\text { medio utilizado para su presentación. } \\
\text { Dicho registro deberá permitir la } \\
\text { generación de reportes detallados, } \\
\text { identificando todos los aspectos } \\
\text { relacionados al mismo. }\end{array}$ & $\begin{array}{l}\text { Sistema } \\
\text { Eclipse }\end{array}$ & Cumple & \\
\hline \multirow[b]{2}{*}{$\begin{array}{l}\text { Artículo } 6 \text { - Área } \\
\text { de Atención de } \\
\text { Reclamos }\end{array}$} & $\begin{array}{l}\text { 6.1 Para el adecuado funcionamiento } \\
\text { del Sistema de Atención de } \\
\text { Reclamos, las empresas supervisadas } \\
\text { deberán contar con áreas encargadas } \\
\text { de la atención de los reclamos. }\end{array}$ & $\begin{array}{l}\text { Agencias y } \\
\text { backoffice de } \\
\text { atención al } \\
\text { usuario }\end{array}$ & Cumple & \multirow{2}{*}{$\begin{array}{l}\text { 1. Estructura } \\
\text { organizacional } \\
\text { inapropiada. } \\
\text { Falta de } \\
\text { segregación de } \\
\text { funciones y } \\
\text { entrenamiento } \\
\text { inapropiado } \\
\text { puede resultar } \\
\text { en manejo } \\
\text { inadecuado de } \\
\text { las quejas del } \\
\text { cliente y } \\
\text { exposición del }\end{array}$} \\
\hline & $\begin{array}{l}\text { 6.2 Las empresas deberán } \\
\text { designar un responsable que tendrá a } \\
\text { su cargo la supervisión y/o } \\
\text { coordinación de las áreas encargadas } \\
\text { de la atención de los reclamos, } \\
\text { debiéndose informar de su } \\
\text { designación a esta Superintendencia } \\
\text { dentro de los quince (15) días } \\
\text { posteriores al inicio del ejercicio de }\end{array}$ & $\begin{array}{l}\text { Oficial de } \\
\text { atención al } \\
\text { usuario es el } \\
\text { gerente de } \\
\text { atención al } \\
\text { usuario }\end{array}$ & Cumple & \\
\hline
\end{tabular}




\begin{tabular}{|c|c|c|c|c|}
\hline Referencia Norma & Descripción & $\begin{array}{c}\text { Evidencia } \\
\text { Área de } \\
\text { atención al } \\
\text { usuario }\end{array}$ & $\begin{array}{l}\text { Análisis } \\
\text { Auditoría } \\
\text { Interna }\end{array}$ & $\begin{array}{c}\text { Riesgo } \\
\text { asociado }\end{array}$ \\
\hline & sus funciones. & & & $\begin{array}{l}\text { banco a } \\
\text { sanciones del } \\
\text { regulador. }\end{array}$ \\
\hline & $\begin{array}{l}\text { 6.3 Cualquier modificación } \\
\text { sustantiva respecto a la información } \\
\text { señalada en el punto } 6.2 \text {, deberá ser } \\
\text { comunicada a la Superintendencia } \\
\text { dentro de los quince (15) días de } \\
\text { haber sido realizada. }\end{array}$ & No aplica & Cumple & \\
\hline \multirow{3}{*}{$\begin{array}{l}\text { Artículo } 7 \text { - } \\
\text { Responsable del } \\
\text { Área de Atención } \\
\text { de Reclamos }\end{array}$} & $\begin{array}{l}\text { 7.1 El responsable del área de } \\
\text { atención de reclamos velará por la } \\
\text { implementación y cumplimiento de } \\
\text { las políticas y procedimientos de la } \\
\text { empresa supervisada. }\end{array}$ & $\begin{array}{l}\text { Manual de } \\
\text { organización } \\
\text { y funciones }\end{array}$ & Cumple & \multirow{3}{*}{$\begin{array}{l}\text { 1. Estructura } \\
\text { organizacional } \\
\text { inapropiada. } \\
\text { Falta de } \\
\text { segregación de } \\
\text { funciones y } \\
\text { entrenamiento } \\
\text { inapropiado } \\
\text { puede resultar } \\
\text { en manejo } \\
\text { inadecuado de } \\
\text { las quejas del } \\
\text { cliente y } \\
\text { exposición del } \\
\text { banco a } \\
\text { sanciones del } \\
\text { regulador. }\end{array}$} \\
\hline & $\begin{array}{l}\text { 7.2 El responsable deberá coordinar } \\
\text { directamente con la PAU cuando se } \\
\text { trate de requerimientos y acciones } \\
\text { efectuadas por ésta, en atención a las } \\
\text { consultas y denuncias presentadas } \\
\text { ante dicho órgano por los usuarios } \\
\text { de las empresas supervisadas o por } \\
\text { terceros. }\end{array}$ & $\begin{array}{l}\text { Manual de } \\
\text { organización } \\
\text { y funciones }\end{array}$ & Cumple & \\
\hline & $\begin{array}{l}\text { 7.3 En el caso de las empresas } \\
\text { supervisadas comprendidas en el } \\
\text { ámbito de aplicación del Reglamento } \\
\text { de transparencia, el mencionado } \\
\text { responsable deberá coordinar de } \\
\text { manera permanente con el Oficial de } \\
\text { Atención al Usuario sobre los } \\
\text { aspectos regulados en la presente } \\
\text { circular. }\end{array}$ & No aplica & Cumple & \\
\hline \multirow[t]{2}{*}{$\begin{array}{l}\text { Artículo 8 - } \\
\text { Informes de } \\
\text { Gestión }\end{array}$} & $\begin{array}{l}\text { 8.1 El responsable del área de } \\
\text { atención de reclamos elaborará } \\
\text { informes trimestrales sobre la } \\
\text { evolución en la atención de los } \\
\text { reclamos. } \\
\text { Los resultados de los referidos } \\
\text { informes deberán ser coordinados } \\
\text { con las áreas involucradas y puestos } \\
\text { en conocimiento de la Gerencia } \\
\text { General y con el Oficial de Atención } \\
\text { al Usuario. }\end{array}$ & $\begin{array}{l}\text { Manual de } \\
\text { organización } \\
\text { y funciones }\end{array}$ & Cumple & \multirow[t]{2}{*}{$\begin{array}{l}6 . \\
\text { Administración } \\
\text { inapropiada y } \\
\text { atrasada de los } \\
\text { reportes de } \\
\text { quejas } \\
\text { trimestrales } \\
\text { regulatorios } \\
\text { expone al } \\
\text { banco a } \\
\text { sanciones del } \\
\text { regulador. }\end{array}$} \\
\hline & $\begin{array}{l}8.2 \text { En todos los casos, los informes } \\
\text { de gestión deberán estar a }\end{array}$ & No aplica & Cumple & \\
\hline
\end{tabular}




\begin{tabular}{|c|c|c|c|c|}
\hline Referencia Norma & Descripción & $\begin{array}{l}\text { Evidencia } \\
\text { Área de } \\
\text { atención al } \\
\text { usuario }\end{array}$ & $\begin{array}{l}\text { Análisis } \\
\text { Auditoría } \\
\text { Interna }\end{array}$ & $\begin{array}{c}\text { Riesgo } \\
\text { asociado }\end{array}$ \\
\hline & disposición de la Superintendencia. & & & \\
\hline \multirow{4}{*}{$\begin{array}{l}\text { Artículo 9 - } \\
\text { Procedimiento } \\
\text { para la } \\
\text { presentación, } \\
\text { tramitación y } \\
\text { resolución de los } \\
\text { reclamos }\end{array}$} & $\begin{array}{l}\text { Presentación, admisión y } \\
\text { tramitación.- } \\
\text { 9.1 Los usuarios tienen derecho a } \\
\text { presentar sus reclamos por los } \\
\text { canales a que se refiere el numeral } \\
5.3\end{array}$ & $\begin{array}{l}\text { Página web, } \\
\text { Call center }\end{array}$ & Cumple & \multirow{4}{*}{$\begin{array}{l}\text { 3. Procesos } \\
\text { inapropiados } \\
\text { para registrar } \\
\text { las quejas de } \\
\text { clientes expone } \\
\text { al banco a } \\
\text { sanciones del } \\
\text { regulador. }\end{array}$} \\
\hline & $\begin{array}{l}\text { 9.2 Al momento de la presentación } \\
\text { de los reclamos, las empresas } \\
\text { deberán registrar los datos } \\
\text { personales del usuario y la dirección } \\
\text { domiciliaria o electrónica a la cual } \\
\text { deberán remitir la comunicación de } \\
\text { respuesta, a elección del usuario. } \\
\text { Adicionalmente, en dicha } \\
\text { oportunidad, las partes podrán pactar } \\
\text { un mecanismo de respuesta } \\
\text { diferente, para el caso de los } \\
\text { reclamos que se resuelvan a favor de } \\
\text { los usuarios, tales como, la página } \\
\text { web, vía telefónica, estados de } \\
\text { cuenta, entre otros }\end{array}$ & $\begin{array}{l}\text { Reporte del } \\
\text { sistema } \\
\text { Eclipse }\end{array}$ & Cumple & \\
\hline & $\begin{array}{l}\text { 9.3 Las empresas podrán diseñar } \\
\text { formatos distintos a los } \\
\text { contemplados en los precitados } \\
\text { anexos para la generación del reporte } \\
\text { de recepción del reclamo, siempre } \\
\text { que contemple como mínimo la } \\
\text { información considerada en el } \\
\text { Anexo } N^{\circ} 1 \text { - A, B o C, según } \\
\text { corresponda }\end{array}$ & $\begin{array}{l}\text { Reporte del } \\
\text { sistema } \\
\text { Eclipse }\end{array}$ & Cumple & \\
\hline & $\begin{array}{l}\text { Finalización.- } \\
\text { 9.4 Tratándose de reclamos resueltos } \\
\text { a favor de las empresas supervisadas, } \\
\text { éstas deberán fundamentar sus } \\
\text { decisiones en la comunicación de } \\
\text { respuesta adjuntando, de ser el caso, } \\
\text { copia del documento de sustento } \\
\text { correspondiente. }\end{array}$ & $\begin{array}{l}\text { Modelo Carta } \\
\text { respuesta }\end{array}$ & Cumple & \\
\hline $\begin{array}{l}\text { Artículo } 10 \text { - } \\
\text { Computo de Plazos }\end{array}$ & $\begin{array}{l}\text { 10.1 Los reclamos deberán ser } \\
\text { resueltos en un plazo no mayor de } \\
\text { treinta (30) días de haber sido } \\
\text { presentados. }\end{array}$ & $\begin{array}{l}\text { Manual de } \\
\text { atención al } \\
\text { usuario }\end{array}$ & Cumple & $\begin{array}{l}4 . \\
\text { Administración } \\
\text { inapropiada y } \\
\text { tardía de }\end{array}$ \\
\hline
\end{tabular}




\begin{tabular}{|c|c|c|c|c|}
\hline Referencia Norma & Descripción & $\begin{array}{c}\text { Evidencia } \\
\text { Área de } \\
\text { atención al } \\
\text { usuario }\end{array}$ & $\begin{array}{c}\text { Análisis } \\
\text { Auditoría } \\
\text { Interna }\end{array}$ & $\begin{array}{c}\text { Riesgo } \\
\text { asociado }\end{array}$ \\
\hline & $\begin{array}{l}\text { 10.2 Dichos plazos sólo podrán } \\
\text { extenderse, excepcionalmente, } \\
\text { siempre que la naturaleza del } \\
\text { reclamo lo justifique, lo cual deberá } \\
\text { ser sustentado a requerimiento de la } \\
\text { Superintendencia } \\
10.3 \text { El cómputo del plazo para la } \\
\text { atención de los reclamos se iniciará } \\
\text { desde la fecha de presentación del } \\
\text { reclamo ante las empresas } \\
\text { supervisadas hasta la fecha de } \\
\text { recepción de la comunicación de } \\
\text { respuesta definitiva por parte del } \\
\text { usuario, } \\
\text { En caso de notificaciones a la } \\
\text { dirección domiciliaria, éstas deberán } \\
\text { ser sustentadas por la empresa } \\
\text { supervisada, debiendo conservar en } \\
\text { sus archivos los respectivos cargos } \\
\text { de recepción de las comunicaciones } \\
\text { remitidas }\end{array}$ & $\begin{array}{l}\text { Manual de } \\
\text { atención al } \\
\text { usuario }\end{array}$ & Cumple & $\begin{array}{l}\text { quejas de } \\
\text { clientes expone } \\
\text { al banco a } \\
\text { sanciones del } \\
\text { regulador. }\end{array}$ \\
\hline $\begin{array}{l}\text { Artículo } 11 \text { - } \\
\text { Archivo de } \\
\text { documentación }\end{array}$ & $\begin{array}{l}\text { 11.1 Las empresas implementarán } \\
\text { mecanismos que permitan el archivo } \\
\text { adecuado de los expedientes } \\
\text { 11.3 Las empresas podrán hacer uso } \\
\text { de herramientas tecnológicas en } \\
\text { materia de archivo de documentos e } \\
\text { información }\end{array}$ & $\begin{array}{l}\text { Manual de } \\
\text { atención al } \\
\text { usuario / } \\
\text { Carpeta } \\
\text { compartida }\end{array}$ & Cumple & $\begin{array}{l}\text { 5. Inapropiada } \\
\text { administración } \\
\text { de los archivos } \\
\text { de quejas de } \\
\text { los clientes } \\
\text { expone al } \\
\text { banco a } \\
\text { sanciones del } \\
\text { regulador. }\end{array}$ \\
\hline $\begin{array}{l}\text { Artículo } 12 \text { - } \\
\text { Información al } \\
\text { Usuario }\end{array}$ & $\begin{array}{l}\text { 12.1 Las empresas deberán mantener } \\
\text { a disposición de los usuarios en } \\
\text { todos sus establecimientos abiertos } \\
\text { al público, en un lugar visible y de } \\
\text { fácil acceso, afiches y/o folletos con } \\
\text { información sobre los } \\
\text { procedimientos de atención de } \\
\text { consultas y reclamos }\end{array}$ & $\begin{array}{l}\text { Agencias y } \\
\text { página web }\end{array}$ & Cumple & $\begin{array}{l}\text { 2. Difusión } \\
\text { inapropiada de } \\
\text { la } \\
\text { administración } \\
\text { de quejas y } \\
\text { procesos de } \\
\text { presentación } \\
\text { limitan el nivel } \\
\text { de información } \\
\text { disponible para } \\
\text { los clientes y } \\
\text { expone al } \\
\text { banco a } \\
\text { sanciones del } \\
\text { regulador. }\end{array}$ \\
\hline
\end{tabular}




\begin{tabular}{|c|c|c|c|c|}
\hline Referencia Norma & Descripción & $\begin{array}{l}\text { Evidencia } \\
\text { Área de } \\
\text { atención al } \\
\text { usuario }\end{array}$ & $\begin{array}{l}\text { Análisis } \\
\text { Auditoría } \\
\text { Interna }\end{array}$ & $\begin{array}{c}\text { Riesgo } \\
\text { asociado }\end{array}$ \\
\hline $\begin{array}{l}\text { Artículo } 13 \text { - } \\
\text { Indicadores de } \\
\text { Gestión }\end{array}$ & $\begin{array}{l}\text { 13.1 Las empresas deberán } \\
\text { establecer indicadores de gestión que } \\
\text { constituyan mecanismos de control } \\
\text { para el adecuado manejo del Sistema } \\
\text { de Atención a los Usuarios } \\
\text { Cualquier modificación de los } \\
\text { referidos indicadores deberá ser } \\
\text { informada a esta Superintendencia } \\
\text { dentro de los quince (15) días de } \\
\text { haber sido realizada. }\end{array}$ & $\begin{array}{l}\text { Informes } \\
\text { mensuales de } \\
\text { atención al } \\
\text { usuario }\end{array}$ & Cumple & \multirow{4}{*}{$\begin{array}{l}6 . \\
\text { Administración } \\
\text { inapropiada y } \\
\text { atrasada de los } \\
\text { reportes de } \\
\text { quejas } \\
\text { trimestrales } \\
\text { regulatorios } \\
\text { expone al } \\
\text { banco a } \\
\text { sanciones del } \\
\text { regulador. }\end{array}$} \\
\hline $\begin{array}{l}\text { Artículo } 14 \text { - } \\
\text { Difusión de } \\
\text { información de } \\
\text { Reclamos recibidos } \\
\text { a través de la } \\
\text { página web }\end{array}$ & $\begin{array}{l}\text { 14.1 Cada empresa supervisada } \\
\text { deberá difundir, a través de su } \\
\text { página web, la información } \\
\text { estadística relativa a los reclamos } \\
\text { presentados por los usuarios. La } \\
\text { información que se difunda deberá } \\
\text { mostrar el total de reclamos } \\
\text { atendidos por la empresa, } \\
\text { clasificados por las diez (10) } \\
\text { operaciones, servicios o productos } \\
\text { que con mayor frecuencia sean } \\
\text { objeto de reclamo al último trimestre } \\
\text { informado a esta Superintendencia, } \\
\text { señalando los tres (3) motivos más } \\
\text { frecuentes de reclamo }\end{array}$ & Página web & Cumple & \\
\hline $\begin{array}{l}\text { Artículo 15- } \\
\text { Comunicación de } \\
\text { Estadísticas }\end{array}$ & $\begin{array}{l}\text { 15.1 Las empresas supervisadas } \\
\text { deben reportar trimestralmente a la } \\
\text { Superintendencia, dentro de los } \\
\text { quince (15) días posteriores al cierre } \\
\text { de cada trimestre calendario, las } \\
\text { estadísticas de los reclamos } \\
\text { presentados por sus correspondientes } \\
\text { usuarios }\end{array}$ & $\begin{array}{l}\text { Informe } \\
\text { trimestral a la } \\
\text { SBS }\end{array}$ & Cumple & \\
\hline $\begin{array}{l}\text { Artículo } 16 \text { - } \\
\text { Evaluación de la } \\
\text { gestión }\end{array}$ & $\begin{array}{l}\text { La existencia y el adecuado } \\
\text { funcionamiento del área de atención } \\
\text { de reclamos será considerada por } \\
\text { esta Superintendencia en la } \\
\text { evaluación de la gestión que realicen } \\
\text { a las entidades supervisadas. } \\
\text { Auditoría interna también debe } \\
\text { evaluarlos. }\end{array}$ & No aplica & Cumple & \\
\hline
\end{tabular}

Fuente: Elaboración Propia.

Como conclusión de esta revisión preliminar, se pudo determinar que existen los documentos que evidencian el cumplimiento de cada artículo de la citada norma, sin 
embargo, es necesario determinar si los controles diseñados son efectivos y cumplen con los criterios descritos en la sección anterior.

\section{Evaluación del funcionamiento de los controles}

La evaluación del diseño de los controles se realizó en base a los criterios establecidos en esta sección de acuerdo a las preguntas de ¿Qué se controla? ¿Quién lo realiza? ¿Cómo lo realiza? ¿Cuándo lo realiza? ¿Dónde lo realiza?

Las evidencias respectivas y formatos se pueden verificar en el ANEXO $\mathrm{N}^{\circ} 3-$ Pruebas de Diseño de Controles. Sin embargo, a manera de ilustración se presenta el formato de la prueba respectivo:

Tabla 5.100 - Formato de Prueba de Diseño de Controles

PCD 3.1 - PRUEBA DISEÑO DE CONTROLES
AI 001 - Retail - Atención de Reclamos - Perú
$\underline{\text { Riesgo: }}$
Procesos inapropiados para registrar las quejas de clientes expone al banco a análisis
regulatorios.
Control clave mitigante del riesgo:
En cada reclamo recibido, el agente de agencia o call center registra la información del
cliente y el reclamo en el sistema de reclamos Eclipse de acuerdo a los requerimientos
mínimos de información establecidos en el manual de atención al usuario. Este control
se encuentra evidenciado a través de los reportes emitidos por el sistema los cuales son
firmados por el cliente o enviados a su correo.
Prueba de efectividad del diseño del control:
Evaluación de que existen controles internos adecuados que aseguren el registro de
quejas y solicitudes en el sistema de administración de los reclamos.




\begin{tabular}{|c|c|c|}
\hline Preguntas de diseño & Evidencia & Conclusión $(\mathrm{S} / \mathrm{N})$ \\
\hline $\begin{array}{l}1 . \quad \text { ¿Es este el control } \\
\text { adecuado para mitigar el riesgo? }\end{array}$ & $\begin{array}{l}\text { - } \quad \text { Reporte de } \\
\text { registro de reclamos }\end{array}$ & $\begin{array}{l}\text { Si } \\
\text { Debido a que se encuentra formalizado } \\
\text { y automatizado. }\end{array}$ \\
\hline $\begin{array}{l}2 . \quad ¿ E l \text { control es ejecutado } \\
\text { por la persona adecuada en el } \\
\text { nivel jerárquico apropiado? }\end{array}$ & & $\begin{array}{l}\text { Si } \\
\text { El agente de agencia o call center } \\
\text { registra cada caso en el sistema y no } \\
\text { participa del proceso de evaluación de } \\
\text { caso. }\end{array}$ \\
\hline $\begin{array}{l}\text { 3. ¿El control se ejecuta en } \\
\text { la etapa adecuada del proceso? }\end{array}$ & & \begin{tabular}{l}
\multicolumn{1}{c}{$\mathbf{S i}$} \\
Debido a que se revisa previo a su \\
registro. Se trata de un control \\
preventivo.
\end{tabular} \\
\hline $\begin{array}{l}\text { 4. ¿El control es } \\
\text { sostenible? }\end{array}$ & & $\begin{array}{l}\text { Si } \\
\text { El control es sostenible debido a que se } \\
\text { encuentra formalizado en el manual de } \\
\text { atención al usuario el cual ha sido } \\
\text { debidamente difundido. } \\
\text { En tal sentido, a pesar de que el persona } \\
\text { rote en la compañía este procedimiento } \\
\text { se encuentra dentro de las funciones de } \\
\text { agente de atención al usuario por lo que } \\
\text { el control seguiría funcionando ante } \\
\text { eventos de rotación de personal. }\end{array}$ \\
\hline $\begin{array}{l}\text { 5. ¿El control se encuentra } \\
\text { evidenciado? }\end{array}$ & $\begin{array}{l}-\quad \text { Manual de } \\
\text { atención al usuario. } \\
-\quad \text { Reporte de } \\
\text { registro de reclamos. }\end{array}$ & $\begin{array}{l}\text { Si } \\
\text { El reporte de registro de reclamos } \\
\text { contiene los datos requeridos del cliente } \\
\text { y el caso así como la firma del cliente o } \\
\text { su envío por correo en caso de llamadas. }\end{array}$ \\
\hline
\end{tabular}

\section{Conclusión:}

El control funciona adecuadamente a nivel diseño debido a que ha podido validarse la existencia del documento y que existen mecanismos internos para su revisión, aprobación y difusión.

\section{Evidencia adjunta:}

- $\quad$ Manual de atención al usuario.

- $\quad$ Reporte de registro de reclamos.

Fuente: Elaboración Propia. 


\subsubsection{Resultado de la etapa de planeación}

La etapa de planeación culmina con la presentación de resultados de las pruebas de diseño y el envío de la matriz de riesgos elaborada por auditoría interna y los flujogramas respectivos al área de atención de reclamos para su confirmación.

Como resultado de las pruebas ejecutadas se concluye que los controles son efectivos a nivel diseño, con ello no habría situaciones que reportar al área de atención de reclamos y se procedería a documentar las evidencias de las pruebas.

\subsection{Trabajo de campo}

\subsubsection{Programa de trabajo}

"Los auditores internos deben preparar y documentar programas que cumplan con el objetivo del trabajo. El programa de trabajo incluye las metodologías a utilizar tales como auditoría interna basada en tecnología y técnicas de muestreo". (IAI, 2013 Norma 2240)

\subsubsection{Selección de Muestras}

Las técnicas de muestreo establecidas por la metodología establecen identificar los controles en base a la frecuencia de los mismos los cuales pueden ser de dos tipos: Controles cíclicos o por ocurrencia.

\section{Controles cíclicos:}
$\checkmark$ Anual
$\checkmark$ Semestral
$\checkmark$ Trimestral
$\checkmark$ Semanal
$\checkmark$ Múltiple por día

\section{Controles por ocurrencia (Transacciones)}

$$
\begin{array}{ll}
- & 1-5 \\
- & 6-50 \\
- & 51-200
\end{array}
$$


- $201-500$

$->500$

Así mismo, auditoría interna empleará muestreos no estadísticos debido a que no se cuenta con un software adecuado para efectuarlo.

\section{Tipos de muestreo no estadístico:}

Juicio: El muestreo se basa en el conocimiento del negocio, prácticas de la entidad, riesgos u controles por parte del auditor.

Selección por bloques: Por lo general se utiliza cuando todos los ítems han ocurrido en un mismo periodo de tiempo o secuencia de transacciones.

Al azar: Realizado sin seguir una técnica estructurada evitando omitir algún criterio.

\section{Consideraciones del muestreo:}

Las muestras se basan en la expectativa de no encontrar excepciones. Si alguna excepción es identificada se debe determinar si el control no está operando adecuadamente y en caso sea 1 sola excepción se debe extender la muestra por la misma cantidad.

Así mismo, basados en la evaluación del riesgo de que el control falle se debe seleccionar una menor o mayor cantidad de muestras (o justificar por se ha elegido una cantidad diferente).

Por otro lado, utilizando el juicio para el muestreo, el auditor puede seleccionar muestras que apunten a características específicas del riesgo de una población para efectos del testeo.

A continuación, se presenta una evaluación preliminar de la frecuencia de controles y definición de las pruebas aplicables: 
Tabla 5.111 - Resumen del muestreo a realizarse

\begin{tabular}{|c|c|c|c|c|c|}
\hline RIESGO & CONTROL CLAVE & $\begin{array}{l}\text { POBLACIÓN } \\
\text { AUDITABLE }\end{array}$ & MUESTRA & $\begin{array}{c}\text { OBJETIVO } \\
\text { DEL TESTEO }\end{array}$ & ¿FDM? ${ }^{1}$ \\
\hline \multirow{3}{*}{$\begin{array}{l}\text { 1. Estructura } \\
\text { organizacional } \\
\text { inapropiada. } \\
\text { Falta de } \\
\text { segregación de } \\
\text { funciones y } \\
\text { entrenamiento } \\
\text { inapropiado } \\
\text { puede resultar en } \\
\text { manejo } \\
\text { inadecuado de las } \\
\text { quejas del cliente } \\
\text { y exposición del } \\
\text { banco a } \\
\text { sanciones del } \\
\text { regulador. }\end{array}$} & $\begin{array}{l}\text { 1.1 Anualmente, el } \\
\text { Gerente de atención de } \\
\text { reclamos actualiza el } \\
\text { manual de políticas y } \\
\text { procedimientos } \\
\text { mediante la inclusión } \\
\text { de los cambios } \\
\text { realizados en el año y } \\
\text { lo envía para su } \\
\text { aprobación en sesión } \\
\text { de directorio. El } \\
\text { control se encuentra } \\
\text { evidenciado a través } \\
\text { del acta de sesión de } \\
\text { directorio. }\end{array}$ & $\begin{array}{l}1 \text { Evento } \\
\text { identificado } \\
\text { debido a que se } \\
\text { realizó una } \\
\text { actualización al } \\
\text { manual durante } \\
\text { el periodo de } \\
\text { revisión. }\end{array}$ & NA & $\begin{array}{l}\text { No requiere } \\
\text { muestreo debido } \\
\text { a que se ha } \\
\text { probado este } \\
\text { único evento en } \\
\text { la prueba de } \\
\text { diseño. }\end{array}$ & No \\
\hline & $\begin{array}{l}\text { 1.2 Anualmente, el } \\
\text { Gerente de atención al } \\
\text { cliente elabora el plan } \\
\text { anual de capacitación } \\
\text { en base a la cantidad } \\
\text { de trabajadores y un } \\
\text { cronograma de } \\
\text { sesiones de } \\
\text { entrenamiento. El } \\
\text { control se encuentra } \\
\text { evidenciado a través de } \\
\text { dicho plan y su } \\
\text { aprobación mediante } \\
\text { sesión de directorio. }\end{array}$ & $\begin{array}{l}1 \text { Evento } \\
\text { identificado } \\
\text { debido a que se } \\
\text { elaboró y } \\
\text { presentó un } \\
\text { único plan } \\
\text { durante el } \\
\text { periodo de } \\
\text { revisión. }\end{array}$ & NA & $\begin{array}{l}\text { No requiere } \\
\text { muestreo debido } \\
\text { a que se ha } \\
\text { probado este } \\
\text { único evento en } \\
\text { la prueba de } \\
\text { diseño. }\end{array}$ & No \\
\hline & $\begin{array}{l}\text { 1.3 En caso de } \\
\text { reemplazo del oficial } \\
\text { de atención al usuario, } \\
\text { el directorio designa a } \\
\text { un nuevo responsable } \\
\text { mediante sesión. Este } \\
\text { control es evidenciado } \\
\text { a través de las actas de } \\
\text { directorio y la } \\
\text { posterior } \\
\text { comunicación a la } \\
\text { SBS. }\end{array}$ & $\begin{array}{l}\text { No se han } \\
\text { identificado } \\
\text { eventos ya que el } \\
\text { oficial de } \\
\text { atención al } \\
\text { usuario fue } \\
\text { elegido antes del } \\
\text { periodo de } \\
\text { revisión. }\end{array}$ & NA & $\begin{array}{l}\text { No requiere } \\
\text { muestreo debido } \\
\text { a que se ha } \\
\text { probado el } \\
\text { funcionamiento } \\
\text { de este control } \\
\text { únicamente a } \\
\text { nivel diseño. }\end{array}$ & No \\
\hline
\end{tabular}

\footnotetext{
${ }^{1}$ Formato de Muestreo
} 


\begin{tabular}{|c|c|c|c|c|c|}
\hline RIESGO & CONTROL CLAVE & $\begin{array}{l}\text { POBLACIÓN } \\
\text { AUDITABLE }\end{array}$ & MUESTRA & $\begin{array}{c}\text { OBJETIVO } \\
\text { DEL TESTEO }\end{array}$ & ¿FDM? ${ }^{1}$ \\
\hline $\begin{array}{l}2 . \quad \text { Difusión } \\
\text { inapropiada de la } \\
\text { administración de } \\
\text { quejas y procesos } \\
\text { de presentación } \\
\text { limitan el nivel } \\
\text { de información } \\
\text { disponible para } \\
\text { los clientes y } \\
\text { expone al banco } \\
\text { a sanciones del } \\
\text { regulador. }\end{array}$ & $\begin{array}{l}\text { 2.1 Mensualmente, el } \\
\text { supervisor de atención } \\
\text { al usuario verifica la } \\
\text { disponibilidad de } \\
\text { folletería informativa } \\
\text { del proceso de } \\
\text { atención de reclamos } \\
\text { en agencias y en la } \\
\text { página web. Este } \\
\text { control se encuentra } \\
\text { evidenciado a través } \\
\text { del checklist de } \\
\text { revisión documentaria } \\
\text { el cual es firmado por } \\
\text { el gerente de tienda y } \\
\text { el supervisor. }\end{array}$ & $\begin{array}{l}\text { Los controles } \\
\text { mensuales tienen } \\
\text { un tratamiento } \\
\text { establecido de } \\
\text { acuerdo a la tabla } \\
\text { de muestreo de } \\
\text { controles } \\
\text { cíclicos. }\end{array}$ & 4 & $\begin{array}{l}\text { La muestra se } \\
\text { seleccionará por } \\
4 \text { agencias y se } \\
\text { verificará que el } \\
\text { último mes del } \\
\text { periodo de } \\
\text { revisión la } \\
\text { existencia del } \\
\text { checklist y así } \\
\text { mismo se } \\
\text { validará en la } \\
\text { misma agencia } \\
\text { la } \\
\text { disponibilidad } \\
\text { de los folletos. }\end{array}$ & SI \\
\hline $\begin{array}{l}3 . \quad \text { Procesos } \\
\text { inapropiados para } \\
\text { registrar las } \\
\text { quejas de clientes } \\
\text { expone al banco } \\
\text { a sanciones del } \\
\text { regulador. }\end{array}$ & $\begin{array}{l}\text { 3.1 En cada reclamo } \\
\text { recibido, el agente de } \\
\text { agencia o call center } \\
\text { registra la información } \\
\text { del cliente y el reclamo } \\
\text { en el sistema de } \\
\text { reclamos Eclipse de } \\
\text { acuerdo a los } \\
\text { requerimientos } \\
\text { mínimos de } \\
\text { información } \\
\text { establecidos en el } \\
\text { manual de atención al } \\
\text { usuario. Este control se } \\
\text { encuentra evidenciado } \\
\text { a través de los reportes } \\
\text { emitidos por el sistema } \\
\text { los cuales son firmados } \\
\text { por el cliente o } \\
\text { enviados a su correo. }\end{array}$ & $\begin{array}{l}\text { 13, } 499 \text { reclamos } \\
\text { recibidos durante } \\
\text { el periodo de } \\
\text { revisión, este } \\
\text { control es por } \\
\text { evento (Ad Hoc) } \\
\text { con lo cual el } \\
\text { muestreo se } \\
\text { realizará en base } \\
\text { a la escala de } \\
\text { eventos del } \\
\text { formato de } \\
\text { muestreo (FDM) }\end{array}$ & 40 & $\begin{array}{l}\text { Se revisarán } 40 \\
\text { casos mediante } \\
\text { muestreo } \\
\text { aleatorio y se } \\
\text { verificará el } \\
\text { correcto registro } \\
\text { en el sistema. }\end{array}$ & SI \\
\hline $\begin{array}{l}4 . \\
\text { Administración } \\
\text { inapropiada y } \\
\text { tardía de quejas } \\
\text { de relientes } \\
\text { expone al banco } \\
\text { a sanciones del } \\
\text { regulador. }\end{array}$ & $\begin{array}{l}\text { 4.1 Diariamente, el } \\
\text { analista backoffice de } \\
\text { servicio al cliente } \\
\text { monitorea los plazos } \\
\text { de atención de } \\
\text { reclamos mediante } \\
\text { reportes diarios de } \\
\text { rastreo de casos } \\
\text { emitido por el sistema } \\
\text { eclipse. Este control se } \\
\text { encuentra evidenciado } \\
\text { a través del cuadro de } \\
\text { control de } \\
\text { anticuamiento. }\end{array}$ & $\begin{array}{l}\text { Los controles } \\
\text { diarios tienen un } \\
\text { tratamiento } \\
\text { establecido de } \\
\text { acuerdo a la tabla } \\
\text { de muestreo de } \\
\text { controles } \\
\text { cíclicos. Sin } \\
\text { embargo, no se } \\
\text { pretende validar } \\
\text { si existen los } \\
\text { reportes de } \\
\text { seguimiento sino } \\
\text { el cumplimiento } \\
\text { efectivo del } \\
\text { plazo regulatorio. }\end{array}$ & & $\begin{array}{l}\text { Por los casos } \\
\text { revisados en la } \\
\text { prueba } 3.1, \text { se } \\
\text { verificará que a } \\
\text { la fecha } \\
\text { determinada los } \\
\text { casos no hayan } \\
\text { superado los } 30 \\
\text { días mediante } \\
\text { contrastación } \\
\text { con el reporte } \\
\text { cortado a dicha } \\
\text { fecha. }\end{array}$ & 3.1 \\
\hline
\end{tabular}




\begin{tabular}{|c|c|c|c|c|c|}
\hline $\mathbf{R}$ & CONTROL CLAVE & $\begin{array}{l}\text { POBLACIÓN } \\
\text { AUDITABLE }\end{array}$ & MUESTRA & $\begin{array}{c}\text { OBJETIVO } \\
\text { DEL TESTEO }\end{array}$ & ¿FDM? ${ }^{1}$ \\
\hline $\begin{array}{l}\text { 5. Inapropiada } \\
\text { administración de } \\
\text { los archivos de } \\
\text { quejas de los } \\
\text { clientes expone } \\
\text { al banco a } \\
\text { sanciones } \\
\text { regulador. }\end{array}$ & $\begin{array}{l}\text { 5.1 Diariamente, el } \\
\text { analista de backoffice } \\
\text { de servicio al cliente } \\
\text { almacena los registros } \\
\text { de reclamos en un } \\
\text { sistema repositorio de } \\
\text { imágenes del banco. El } \\
\text { supervisor de servicios } \\
\text { al consumidor ejecuta } \\
\text { la validación semanal } \\
\text { del sistema de } \\
\text { imágenes mediante un } \\
\text { muestreo en el cual } \\
\text { verifica la integridad } \\
\text { de los documentos. } \\
\text { Este control se } \\
\text { encuentra evidenciado } \\
\text { a través de su matriz } \\
\text { de revisión. }\end{array}$ & $\begin{array}{l}\text { Los controles } \\
\text { diarios tienen un } \\
\text { tratamiento } \\
\text { establecido de } \\
\text { acuerdo a la tabla } \\
\text { de muestreo de } \\
\text { controles } \\
\text { cíclicos. Sin } \\
\text { embargo, no se } \\
\text { pretende validar } \\
\text { si existen las } \\
\text { matrices de } \\
\text { revisión sino si } \\
\text { se han } \\
\text { almacenado } \\
\text { adecuadamente } \\
\text { los registros. }\end{array}$ & 40 & $\begin{array}{l}\text { Para los casos } \\
\text { revisados en la } \\
\text { prueba } 3.1 \text { se } \\
\text { verificará el } \\
\text { envío oportuno } \\
\text { a almacén y la } \\
\text { existencia de su } \\
\text { versión } \\
\text { digitalizada. }\end{array}$ & 3.1 \\
\hline $\begin{array}{l}6 . \\
\text { Administración } \\
\text { inapropiada } r \\
\text { atrasada de los } \\
\text { reportes } \\
\text { quejas de } \\
\text { trimestrales } \\
\text { regulatorios } \\
\text { expone al banco } \\
\text { a sanciones del } \\
\text { regulador. }\end{array}$ & $\begin{array}{l}6.1 \text { Trimestralmente, el } \\
\text { supervisor de atención } \\
\text { al usuario elabora } \\
\text { reportes de gestión } \\
\text { estadístico de los } \\
\text { reclamos recibidos en } \\
\text { el periodo y envía al } \\
\text { área de contabilidad } \\
\text { para que lo remitan a } \\
\text { la SBS. Este control se } \\
\text { encuentra evidenciado } \\
\text { a través de los reportes } \\
\text { trimestrales en comité } \\
\text { de gerencia de } \\
\text { atención de reclamos y } \\
\text { el archivo de envío a la } \\
\text { SBS. }\end{array}$ & $\begin{array}{l}\text { Los controles } \\
\text { trimestrales } \\
\text { tienen un } \\
\text { tratamiento } \\
\text { establecido de } \\
\text { acuerdo a la tabla } \\
\text { de muestreo de } \\
\text { controles } \\
\text { cíclicos. }\end{array}$ & 2 & $\begin{array}{l}\text { Para los casos } \\
\text { muestreados se } \\
\text { verificará que } \\
\text { los indicadores } \\
\text { se hayan } \\
\text { presentado a } \\
\text { comité, que se } \\
\text { hayan colgado } \\
\text { en la página } \\
\text { web y que se } \\
\text { hayan } \\
\text { presentado } \\
\text { oportunamente } \\
\text { a la SBS. Por } \\
\text { otro lado, se re } \\
\text { elaborará dicho } \\
\text { reporte. }\end{array}$ & SI \\
\hline
\end{tabular}

Fuente: Elaboración Propia.

Según el cuadro anterior se puede verificar que no todos los controles requieren de pruebas de eficacia de controles.

\subsubsection{Formato de Muestreo (FDM)}

Como evidencia de la adecuada aplicación de técnicas de muestreo se emplea un formato determinado que permite identificar y referenciar la frecuencia de los controles así como la cantidad de muestras que se probarán en el testeo. Los controles a testearse son los siguientes:

$\checkmark$ Control 2.1: Difusión de información de procedimiento de reclamos 
$\checkmark$ Control 3.1, 4.1 y 5.1: Registro, seguimiento y archivo de reclamos (se probarán los 3 controles en una sola prueba para validar el flujo del proceso de atención de reclamos.

$\checkmark$ Control 6.1: Reportes regulatorios

Los formatos de muestreo correspondiente a los controles antes descritos se encuentran detallados en el ANEXO N 4 - Formato de Muestreo.

\subsubsection{Pruebas de Eficacia de Controles (PEC)}

Los auditores internos deben identificar, analizar, evaluar y documentar la suficiente información de manera tal que les permita cumplir con el objetivo del trabajo. (IAI. 2300-1 Desempeño del trabajo).

Así mismo, debe considerarse que toda información de carácter personal debe ser obviada debido a que la regulación peruana ha establecido parámetros mediante la Ley de protección de datos personales.

Los auditores internos pueden usar procedimientos analíticos para obtener pruebas de auditoría. Los procedimientos analíticos requieren el estudio y comparación de las relaciones entre la información financiera y no financiera. Esta aplicación de los procedimientos analíticos se basa en la premisa que, en ausencia de condiciones conocidas que indiquen lo contrario, es de esperar que la relación entre la información existan y continúen. Algunos ejemplos de las condiciones contrarias son las transacciones o acontecimientos inusuales o no recurrentes, de contabilidad, organizacionales, operacionales, del entorno y tecnológicos, ineficiencias, infectividades, errores, fraude o actos ilegales. (IAI, 2013 Consejo para la práctica 2320-1). Los procedimientos analíticos son útiles para la identificación de:

$\checkmark$ Diferencias imprevistas

$\checkmark$ Ausencia de las diferencias previstas

$\checkmark$ Errores potenciales

$\checkmark$ Fraude o actos ilegales potenciales

$\checkmark$ Otras transacciones o acontecimientos inusuales o no recurrentes. 
Los procedimientos analíticos de auditoría incluyen:

$\checkmark$ Comparar la información del periodo actual con la expectativa de información similar de periodos anteriores.

$\checkmark$ Estudiar relaciones entre la información financiera y no financiera apropiada (por ejemplo, gastos de personal registrados comparado con los cambios en el número de empleados).

$\checkmark$ Estudiar las relaciones entre los elementos de información (por ejemplo fluctuación del gasto de intereses registrados comparado con los saldos deudores relacionados)

$\checkmark$ Comparar la información con las expectativas basadas en información similar de otras unidades de la organización así como del sector mismo.

A continuación, se presentan los papeles de trabajo empleados para probar la eficacia de la operatividad de los controles en base a los criterios antes descritos: 
Tabla 5.122 - Formato de Prueba de Eficacia de Controles (PEC) $\mathrm{N}^{\circ} 1.1$

\section{PEC 2.1 - PRUEBA EFICACIA DE CONTROLES}

AI 001 - Retail - Atención de Reclamos - Perú

\section{Riesgo:}

Difusión inapropiada de la administración de quejas y procesos de presentación limitan el nivel de información disponible para los clientes y expone al banco a sanciones del regulador.

\section{Control clave mitigante del riesgo:}

Mensualmente, el supervisor de atención al usuario verifica la disponibilidad de folletería informativa del proceso de atención de reclamos en agencias y en la página web. Este control se encuentra evidenciado a través del checklist de revisión documentaria el cual es firmado por el gerente de tienda y el supervisor.

\section{Objetivo de la prueba de eficacia operativa}

Verificar que la información relacionada a presentar reclamos / quejas a través de sucursales y de la página WEB está fácilmente disponible al público (afiches y / o folletos e información) y responder consultas, quejas o alegatos de la SBS.

\section{ANEXO A: PRUEBAS DE EFICACIA DE CONTROLES}

\section{Pasos preliminares del testing:}

1. Solicitar el total de checklist que se hayan realizado durante el periodo de enero a junio 2014.

2. Seleccionar una muestra aleatoria de 4 checklists

3. Efectúe las siguientes pruebas:

a. Verificar la Oportunidad del checklist mensual, considerar que la política establece que debe realizarse dentro de los 5 primeros días del mes.

b. Firmas del ejecutor y supervisor del checklist.

c. Evidencia de solicitud de reposición de folletería 
d. En caso de haber detectado stock faltante solicitar evidencia de solicitud de reposición

\section{ANEXO B: RESUMEN DE LA REVISIÓN DOCUMENTARIA}

\begin{tabular}{|ll|c|c|c|c|l|}
\hline \multicolumn{2}{|c|}{ Documento a revisar } & a & b & c & d & \multicolumn{1}{|c|}{ Comentarios } \\
\hline 1. & Checklist Enero 2014 & $\checkmark$ & $\checkmark$ & $\checkmark$ & $\checkmark$ & $\begin{array}{l}\text { La documentación es } \\
\text { conforme }\end{array}$ \\
\hline 2. & Checklist Marzo 2014 & $\checkmark$ & $\checkmark$ & $\checkmark$ & $\checkmark$ & $\begin{array}{l}\text { La documentación es } \\
\text { conforme }\end{array}$ \\
\hline 3. & Checklist Mayo 2014 & $\checkmark$ & $\checkmark$ & $\checkmark$ & $\checkmark$ & $\begin{array}{l}\text { La documentación es } \\
\text { conforme }\end{array}$ \\
\hline 4. & Checklist Junio 2014 & $\checkmark$ & $\checkmark$ & $\checkmark$ & $\checkmark$ & $\begin{array}{l}\text { La documentación es } \\
\text { conforme }\end{array}$ \\
\hline
\end{tabular}

\section{Documentación Soporte:}

Checklist Enero, Marzo, Mayo y Junio 2014

\section{ANEXO C: CONCLUSIÓN DE LA PRUEBA:}

\section{Control 2.1: Efectivo}

En base al procedimiento de revisión documentaria, se concluye que el control se encuentra operando eficazmente ya que en los casos revisados se ha cumplido con las actividades diseñadas para mitigar el riesgo de incumplimiento regulatorio.

Fuente: Elaboración Propia. 
Tabla 5.133 - Formato de Prueba de Eficacia de Controles (PEC) $\mathbf{N}^{\circ} 3.1$

\section{PEC 3.1 - PRUEBA EFICACIA DE CONTROLES}

AI 001 - Retail - Atención de Reclamos - Perú

\section{Riesgo:}

3.1 Procesos inapropiados para registrar las quejas de clientes expone al banco a sanciones del regulador.

4.1 Administración inapropiada y tardía de quejas de clientes expone al banco a sanciones del regulador.

5.1 Inapropiada administración de los archivos de quejas de los clientes expone al banco a sanciones del regulador.

\section{Control clave mitigante del riesgo:}

3.1 En cada reclamo recibido, el agente de agencia o call center registra la información del cliente y el reclamo en el sistema de reclamos Eclipse de acuerdo a los requerimientos mínimos de información establecidos en el manual de atención al usuario. Este control se encuentra evidenciado a través de los reportes emitidos por el sistema los cuales son firmados por el cliente o enviados a su correo.

4.1 Diariamente, el analista backoffice de servicio al cliente monitorea los plazos de atención de reclamos mediante reportes diarios de rastreo de casos emitido por el sistema eclipse. Este control se encuentra evidenciado a través del cuadro de control de anticuamiento.

5.1 Diariamente, el analista de backoffice de servicio al cliente almacena los registros de reclamos en un sistema repositorio de imágenes del banco. El supervisor de servicios al consumidor ejecuta la validación semanal del sistema de imágenes mediante un muestreo en el cual verifica la integridad de los documentos. Este control se encuentra evidenciado a través de su matriz de revisión.

Objetivo de la prueba de eficacia de controles 
Evaluar la ejecución de los controles internos adecuados que aseguren que el registro, monitoreo de plazos y resguardo de files de reclamos y solicitudes se efectúa de acuerdo a las políticas del banco y permiten mitigar el riesgo de incumplimiento.

Para ello, se efectuará una sola prueba para probar los 3 controles ya que con una sola muestra se permitirá verificar el proceso de atención de reclamos desde su inicio hasta su culminación.

\section{ANEXO I: PRUEBAS DE EFICACIA DE CONTROLES}

\section{Pasos preliminares del testing:}

1. Solicitar el reporte de reclamos atendidos de enero a junio 2014

2. Verificar si dicho reporte cruza con los datos del reporte regulatorio

3. Seleccionar una muestra aleatoria de 40 expedientes de reclamos en base a la frecuencia y proporción establecida en el documento de muestreo.

4. Efectúe las pruebas correspondientes:

\begin{tabular}{|c|c|}
\hline Control asociado & Descripción de la prueba \\
\hline $\begin{array}{l}\text { 3.1 En cada reclamo recibido, el agente de } \\
\text { agencia o call center registra la información del } \\
\text { cliente y el reclamo en el sistema de reclamos } \\
\text { Eclipse de acuerdo a los requerimientos } \\
\text { mínimos de información establecidos en el } \\
\text { manual de atención al usuario. Este control se } \\
\text { encuentra evidenciado a través de los reportes } \\
\text { emitidos por el sistema los cuales son firmados } \\
\text { por el cliente o enviados a su correo. }\end{array}$ & $\begin{array}{l}\text { a. } \quad \text { Verificar si el reporte Eclipse cuenta con la } \\
\text { firma del cliente. } \\
\text { b. } \quad \text { Verifique si la fecha de registro cruza con la } \\
\text { fecha del reporte Eclipse. } \\
\text { c. } \quad \text { Verificar si se le entregó el mismo día según } \\
\text { la circular SBS g 146-2009. }\end{array}$ \\
\hline $\begin{array}{l}\text { 4.1 Diariamente, el analista backoffice de } \\
\text { servicio al cliente monitorea los plazos de } \\
\text { atención de reclamos mediante reportes diarios } \\
\text { de rastreo de casos emitido por el sistema } \\
\text { eclipse. Este control se encuentra evidenciado a } \\
\text { través del cuadro de control de anticuamiento. }\end{array}$ & $\begin{array}{l}\text { d. } \\
\text { días de respuesta mediante la carta de resolución del } \\
\text { reclamo o que exista una carta de extensión de plazo. } \\
\text { e. } \quad \text { Verificar que se haya registrado la fecha } \\
\text { efectiva en el sistema } \\
\text { f. } \quad \text { Contraste si la muestra seleccionada ha sido } \\
\text { incluida en el reporte de seguimiento del área de } \\
\text { atención cliente. } \\
\text { g. } \quad \text { Verifique si se respetó el medio de respuesta } \\
\text { pactado. }\end{array}$ \\
\hline $\begin{array}{l}\text { 5.1 Diariamente, el analista de backoffice de } \\
\text { servicio al cliente almacena los registros de } \\
\text { reclamos en un sistema repositorio de imágenes }\end{array}$ & $\begin{array}{l}\text { h. Verifique que el reporte físico se encuentre } \\
\text { debidamente resguardado (en caso de files enviados a } \\
\text { RANSA, obtener evidencia de su envío y }\end{array}$ \\
\hline
\end{tabular}


del banco. El supervisor de servicios al consumidor ejecuta la validación semanal del sistema de imágenes mediante un muestreo en el cual verifica la integridad de los documentos. Este control se encuentra evidenciado a través de su matriz de revisión. almacenamiento y en caso de los aun mantenidos en custodia validar su archivo en un lugar adecuado y bajo llave).

i. $\quad$ Valide que el reporte digitalizado se encuentre en una ruta compartida con acceso controlado.

\section{ANEXO II: RESUMEN DE LA REVISIÓN DOCUMENTARIA}

\begin{tabular}{|c|c|c|c|c|c|c|c|c|c|c|c|c|c|c|}
\hline \multirow[b]{2}{*}{$\mathbf{N}^{\circ}$} & \multirow[b]{2}{*}{$\begin{array}{l}\text { Expedi- } \\
\text { ente }\end{array}$} & \multirow[b]{2}{*}{$\begin{array}{l}\text { Fecha } \\
\text { Registro }\end{array}$} & \multirow{2}{*}{$\begin{array}{c}\text { Fecha } \\
\text { cierre / } \\
\text { Extensión }\end{array}$} & \multirow[b]{2}{*}{ días } & \multicolumn{3}{|c|}{$\begin{array}{c}\text { Prueba } \\
3.1 \\
\end{array}$} & \multicolumn{4}{|c|}{ Prueba 4.1} & \multicolumn{2}{|c|}{ Prueba 5.1} & \multirow[b]{2}{*}{ Comentarios } \\
\hline & & & & & $\mathbf{a}$ & b & c & d & $\mathbf{e}$ & $\mathbf{f}$ & $\mathbf{g}$ & h & I & \\
\hline 1 & 1001 & $03 / 01 / 2014$ & $30 / 03 / 2014$ & 86 & $\checkmark$ & $\checkmark$ & $\checkmark$ & $x$ & $\checkmark$ & $\checkmark$ & $\checkmark$ & $\checkmark$ & $\checkmark$ & $\begin{array}{l}\text { No se cuenta con } \\
\text { carta de extensión } \\
\text { de plazo }\end{array}$ \\
\hline 2 & 1002 & $05 / 01 / 2014$ & $30 / 03 / 2014$ & 84 & $\checkmark$ & $\checkmark$ & $\checkmark$ & $x$ & $\checkmark$ & $\checkmark$ & $\checkmark$ & $\checkmark$ & $\checkmark$ & $\begin{array}{l}\text { No se cuenta con } \\
\text { carta de extensión } \\
\text { de plazo }\end{array}$ \\
\hline 3 & 1003 & $08 / 01 / 2014$ & $30 / 03 / 2014$ & 81 & $\checkmark$ & $\checkmark$ & $\checkmark$ & $x$ & $\checkmark$ & $\checkmark$ & $\checkmark$ & $\checkmark$ & $\checkmark$ & $\begin{array}{l}\text { No se cuenta con } \\
\text { carta de extensión } \\
\text { de plazo }\end{array}$ \\
\hline 4 & 1004 & $13 / 01 / 2014$ & $30 / 03 / 2014$ & 76 & $\checkmark$ & $\checkmark$ & $\checkmark$ & $x$ & $\checkmark$ & $\checkmark$ & $\checkmark$ & $\checkmark$ & $\checkmark$ & $\begin{array}{l}\text { No se cuenta con } \\
\text { carta de extensión } \\
\text { de plazo }\end{array}$ \\
\hline 5 & 1005 & $22 / 01 / 2014$ & $30 / 03 / 2014$ & 67 & $\checkmark$ & $\checkmark$ & $\checkmark$ & $x$ & $\checkmark$ & $\checkmark$ & $\checkmark$ & $\checkmark$ & $\checkmark$ & $\begin{array}{l}\text { No se cuenta con } \\
\text { carta de extensión } \\
\text { de plazo }\end{array}$ \\
\hline 6 & 1006 & $26 / 01 / 2014$ & $30 / 03 / 2014$ & 63 & $\checkmark$ & $\checkmark$ & $\checkmark$ & $x$ & $\checkmark$ & $\checkmark$ & $\checkmark$ & $\checkmark$ & $\checkmark$ & $\begin{array}{l}\text { No se cuenta con } \\
\text { carta de extensión } \\
\text { de plazo }\end{array}$ \\
\hline 7 & 1007 & $01 / 02 / 2014$ & $30 / 03 / 2014$ & 57 & $\checkmark$ & $\checkmark$ & $\checkmark$ & $x$ & $\checkmark$ & $\checkmark$ & $\checkmark$ & $\checkmark$ & $\checkmark$ & $\begin{array}{l}\text { No se cuenta con } \\
\text { carta de extensión } \\
\text { de plazo }\end{array}$ \\
\hline 8 & 1008 & $07 / 02 / 2014$ & $30 / 03 / 2014$ & 51 & $\checkmark$ & $\checkmark$ & $\checkmark$ & $x$ & $\checkmark$ & $\checkmark$ & $\checkmark$ & $\checkmark$ & $\checkmark$ & $\begin{array}{l}\text { No se cuenta con } \\
\text { carta de extensión } \\
\text { de plazo }\end{array}$ \\
\hline 9 & 1009 & $12 / 02 / 2014$ & $30 / 03 / 2014$ & 46 & $\checkmark$ & $\checkmark$ & $\checkmark$ & $x$ & $\checkmark$ & $\checkmark$ & $\checkmark$ & $\checkmark$ & $\checkmark$ & $\begin{array}{l}\text { No se cuenta con } \\
\text { carta de extensión } \\
\text { de plazo }\end{array}$ \\
\hline 10 & 1010 & $17 / 02 / 2014$ & $03 / 03 / 2014$ & 14 & $\checkmark$ & $\checkmark$ & $\checkmark$ & $\checkmark$ & $\checkmark$ & $\checkmark$ & $\checkmark$ & $\checkmark$ & $\checkmark$ & $\begin{array}{l}\text { La documentación } \\
\text { es conforme }\end{array}$ \\
\hline 11 & 1011 & $23 / 02 / 2014$ & $09 / 03 / 2014$ & 14 & $\checkmark$ & $\checkmark$ & $\checkmark$ & $\checkmark$ & $\checkmark$ & $\checkmark$ & $\checkmark$ & $\checkmark$ & $\checkmark$ & $\begin{array}{l}\text { La documentación } \\
\text { es conforme }\end{array}$ \\
\hline 12 & 1012 & $28 / 02 / 2014$ & $14 / 03 / 2014$ & 14 & $\checkmark$ & $\checkmark$ & $\checkmark$ & $\checkmark$ & $\checkmark$ & $\checkmark$ & $\checkmark$ & $\checkmark$ & $\checkmark$ & $\begin{array}{l}\text { La documentación } \\
\text { es conforme }\end{array}$ \\
\hline 13 & 1013 & $04 / 03 / 2014$ & $18 / 03 / 2014$ & 14 & $\checkmark$ & $\checkmark$ & $\checkmark$ & $\checkmark$ & $\checkmark$ & $\checkmark$ & $\checkmark$ & $\checkmark$ & $\checkmark$ & $\begin{array}{l}\text { La documentación } \\
\text { es conforme }\end{array}$ \\
\hline
\end{tabular}




\begin{tabular}{|c|c|c|c|c|c|c|c|c|c|c|c|c|c|c|}
\hline \multirow[b]{2}{*}{$\mathbf{N}^{\circ}$} & \multirow[b]{2}{*}{$\begin{array}{l}\text { Expedi- } \\
\text { ente }\end{array}$} & \multirow[b]{2}{*}{$\begin{array}{c}\text { Fecha } \\
\text { Registro }\end{array}$} & \multirow[b]{2}{*}{$\begin{array}{c}\text { Fecha } \\
\text { cierre / } \\
\text { Extensión }\end{array}$} & \multirow[b]{2}{*}{ días } & \multicolumn{3}{|c|}{$\begin{array}{c}\text { Prueba } \\
3.1\end{array}$} & \multicolumn{4}{|c|}{ Prueba 4.1} & \multicolumn{2}{|c|}{ Prueba 5.1} & \multirow[b]{2}{*}{ Comentarios } \\
\hline & & & & & $\mathbf{a}$ & b & c & d & $\mathbf{e}$ & f & $\mathbf{g}$ & h & I & \\
\hline 14 & 1014 & $05 / 03 / 2014$ & $19 / 03 / 2014$ & 14 & $\checkmark$ & $\checkmark$ & $\checkmark$ & $\checkmark$ & $\checkmark$ & $\checkmark$ & $\checkmark$ & $\checkmark$ & $\checkmark$ & $\begin{array}{l}\text { La documentación } \\
\text { es conforme }\end{array}$ \\
\hline 15 & 1015 & $13 / 03 / 2014$ & $27 / 03 / 2014$ & 14 & $\checkmark$ & $\checkmark$ & $\checkmark$ & $\checkmark$ & $\checkmark$ & $\checkmark$ & $\checkmark$ & $\checkmark$ & $\checkmark$ & $\begin{array}{l}\text { La documentación } \\
\text { es conforme }\end{array}$ \\
\hline 16 & 1016 & $22 / 03 / 2014$ & $05 / 04 / 2014$ & 14 & $\checkmark$ & $\checkmark$ & $\checkmark$ & $\checkmark$ & $\checkmark$ & $\checkmark$ & $\checkmark$ & $\checkmark$ & $\checkmark$ & $\begin{array}{l}\text { La documentación } \\
\text { es conforme }\end{array}$ \\
\hline 17 & 1017 & $30 / 03 / 2014$ & $13 / 04 / 2014$ & 14 & $\checkmark$ & $\checkmark$ & $\checkmark$ & $\checkmark$ & $\checkmark$ & $\checkmark$ & $\checkmark$ & $\checkmark$ & $\checkmark$ & $\begin{array}{l}\text { La documentación } \\
\text { es conforme }\end{array}$ \\
\hline 18 & 1018 & $05 / 04 / 2014$ & $19 / 04 / 2014$ & 14 & $\checkmark$ & $\checkmark$ & $\checkmark$ & $\checkmark$ & $\checkmark$ & $\checkmark$ & $\checkmark$ & $\checkmark$ & $\checkmark$ & $\begin{array}{l}\text { La documentación } \\
\text { es conforme }\end{array}$ \\
\hline 19 & 1019 & $11 / 04 / 2014$ & $25 / 04 / 2014$ & 14 & $\checkmark$ & $\checkmark$ & $\checkmark$ & $\checkmark$ & $\checkmark$ & $\checkmark$ & $\checkmark$ & $\checkmark$ & $\checkmark$ & $\begin{array}{l}\text { La documentación } \\
\text { es conforme }\end{array}$ \\
\hline 20 & 1020 & $17 / 04 / 2014$ & $01 / 05 / 2014$ & 14 & $\checkmark$ & $\checkmark$ & $\checkmark$ & $\checkmark$ & $\checkmark$ & $\checkmark$ & $\checkmark$ & $\checkmark$ & $\checkmark$ & $\begin{array}{l}\text { La documentación } \\
\text { es conforme }\end{array}$ \\
\hline 21 & 1021 & $21 / 04 / 2014$ & $05 / 05 / 2014$ & 14 & $\checkmark$ & $\checkmark$ & $\checkmark$ & $\checkmark$ & $\checkmark$ & $\checkmark$ & $\checkmark$ & $\checkmark$ & $\checkmark$ & $\begin{array}{l}\text { La documentación } \\
\text { es conforme }\end{array}$ \\
\hline 22 & 1022 & $28 / 04 / 2014$ & $12 / 05 / 2014$ & 14 & $\checkmark$ & $\checkmark$ & $\checkmark$ & $\checkmark$ & $\checkmark$ & $\checkmark$ & $\checkmark$ & $\checkmark$ & $\checkmark$ & $\begin{array}{l}\text { La documentación } \\
\text { es conforme }\end{array}$ \\
\hline 23 & 1023 & $05 / 05 / 2014$ & $19 / 05 / 2014$ & 14 & $\checkmark$ & $\checkmark$ & $\checkmark$ & $\checkmark$ & $\checkmark$ & $\checkmark$ & $\checkmark$ & $\checkmark$ & $\checkmark$ & $\begin{array}{l}\text { La documentación } \\
\text { es conforme }\end{array}$ \\
\hline 24 & 1024 & 09/05/2014 & $23 / 05 / 2014$ & 14 & $\checkmark$ & $\checkmark$ & $\checkmark$ & $\checkmark$ & $\checkmark$ & $\checkmark$ & $\checkmark$ & $\checkmark$ & $\checkmark$ & $\begin{array}{l}\text { La documentación } \\
\text { es conforme }\end{array}$ \\
\hline 25 & 1025 & $13 / 05 / 2014$ & $27 / 05 / 2014$ & 14 & $\checkmark$ & $\checkmark$ & $\checkmark$ & $\checkmark$ & $\checkmark$ & $\checkmark$ & $\checkmark$ & $\checkmark$ & $\checkmark$ & $\begin{array}{l}\text { La documentación } \\
\text { es conforme }\end{array}$ \\
\hline 26 & 1026 & $15 / 05$ & $29 / 05 / 2014$ & 14 & $\checkmark$ & $\checkmark$ & $\checkmark$ & $\checkmark$ & $\checkmark$ & $\checkmark$ & $\checkmark$ & $\checkmark$ & $\checkmark$ & $\begin{array}{l}\text { La documentación } \\
\text { es conforme }\end{array}$ \\
\hline 27 & 1027 & $16 / 05 / 2014$ & $30 / 05 / 2014$ & 14 & $\checkmark$ & $\checkmark$ & $\checkmark$ & $\checkmark$ & $\checkmark$ & $\checkmark$ & $\checkmark$ & $\checkmark$ & $\checkmark$ & $\begin{array}{l}\text { La documentación } \\
\text { es conforme }\end{array}$ \\
\hline 28 & 1028 & $17 / 05 / 2014$ & $31 / 05 / 2014$ & 14 & $\checkmark$ & $\checkmark$ & $\checkmark$ & $\checkmark$ & $\checkmark$ & $\checkmark$ & $\checkmark$ & $\checkmark$ & $\checkmark$ & $\begin{array}{l}\text { La documentación } \\
\text { es conforme }\end{array}$ \\
\hline 29 & 1029 & $18 / 05 / 2014$ & $01 / 06 / 2014$ & 14 & $\checkmark$ & $\checkmark$ & $\checkmark$ & $\checkmark$ & $\checkmark$ & $\checkmark$ & $\checkmark$ & $\checkmark$ & $\checkmark$ & $\begin{array}{l}\text { La documentación } \\
\text { es conforme }\end{array}$ \\
\hline 30 & 1030 & $21 / 05 / 2014$ & $04 / 06 / 2014$ & 14 & $\checkmark$ & $\checkmark$ & $\checkmark$ & $\checkmark$ & $\checkmark$ & $\checkmark$ & $\checkmark$ & $\checkmark$ & $\checkmark$ & $\begin{array}{l}\text { La documentación } \\
\text { es conforme }\end{array}$ \\
\hline 31 & 1031 & $26 / 05 / 2014$ & 09/06/2014 & 14 & $\checkmark$ & $\checkmark$ & $\checkmark$ & $\checkmark$ & $\checkmark$ & $\checkmark$ & $\checkmark$ & $\checkmark$ & $\checkmark$ & $\begin{array}{l}\text { La documentación } \\
\text { es conforme }\end{array}$ \\
\hline 32 & 1032 & $27 / 05 / 2014$ & $10 / 06 / 2014$ & 14 & $\checkmark$ & $\checkmark$ & $\checkmark$ & $\checkmark$ & $\checkmark$ & $\checkmark$ & $\checkmark$ & $\checkmark$ & $\checkmark$ & $\begin{array}{l}\text { La documentación } \\
\text { es conforme }\end{array}$ \\
\hline 33 & 1033 & $01 / 06 / 2014$ & $15 / 06 / 2014$ & 14 & $\checkmark$ & $\checkmark$ & $\checkmark$ & $\checkmark$ & $\checkmark$ & $\checkmark$ & $\checkmark$ & $\checkmark$ & $\checkmark$ & $\begin{array}{l}\text { La documentación } \\
\text { es conforme }\end{array}$ \\
\hline 34 & 1034 & /06/2014 & $18 / 06 / 2014$ & 14 & $\checkmark$ & & $\checkmark$ & $\checkmark$ & $\checkmark$ & $\checkmark$ & $\checkmark$ & $\checkmark$ & $\checkmark$ & $\begin{array}{l}\text { La documentación } \\
\text { es conforme }\end{array}$ \\
\hline
\end{tabular}




\begin{tabular}{|c|c|c|c|c|c|c|c|c|c|c|c|c|c|c|}
\hline \multirow[b]{2}{*}{$\mathbf{N}^{\circ}$} & \multirow[b]{2}{*}{$\begin{array}{l}\text { Expedi- } \\
\text { ente }\end{array}$} & \multirow[b]{2}{*}{$\begin{array}{l}\text { Fecha } \\
\text { Registro }\end{array}$} & \multirow[b]{2}{*}{$\begin{array}{c}\text { Fecha } \\
\text { cierre / } \\
\text { Extensión }\end{array}$} & \multirow[b]{2}{*}{ días } & \multicolumn{3}{|c|}{$\begin{array}{c}\text { Prueba } \\
3.1\end{array}$} & \multicolumn{4}{|c|}{ Prueba 4.1} & \multicolumn{2}{|c|}{ Prueba 5.1} & \multirow[b]{2}{*}{ Comentarios } \\
\hline & & & & & $\mathbf{a}$ & $\mathbf{b}$ & c & d & e & $\mathbf{f}$ & g & h & I & \\
\hline 35 & 1035 & 05/06/2014 & $19 / 06 / 2014$ & 14 & $\checkmark$ & $\checkmark$ & $\checkmark$ & $\checkmark$ & $\checkmark$ & $\checkmark$ & $\checkmark$ & $\checkmark$ & $\checkmark$ & $\begin{array}{l}\text { La documentación } \\
\text { es conforme }\end{array}$ \\
\hline 36 & 1036 & 06/06/2014 & $20 / 06 / 2014$ & 14 & $\checkmark$ & $\checkmark$ & $\checkmark$ & $\checkmark$ & $\checkmark$ & $\checkmark$ & $\checkmark$ & $\checkmark$ & $\checkmark$ & $\begin{array}{l}\text { La documentación } \\
\text { es conforme }\end{array}$ \\
\hline 37 & 1037 & 08/06/2014 & $22 / 06 / 2014$ & 14 & $\checkmark$ & $\checkmark$ & $\checkmark$ & $\checkmark$ & $\checkmark$ & $\checkmark$ & $\checkmark$ & $\checkmark$ & $\checkmark$ & $\begin{array}{l}\text { La documentación } \\
\text { es conforme }\end{array}$ \\
\hline 38 & 1038 & $11 / 06 / 2014$ & $25 / 06 / 2014$ & 14 & $\checkmark$ & $\checkmark$ & $\checkmark$ & $\checkmark$ & $\checkmark$ & $\checkmark$ & $\checkmark$ & $\checkmark$ & $\checkmark$ & $\begin{array}{l}\text { La documentación } \\
\text { es conforme }\end{array}$ \\
\hline 39 & 1039 & $12 / 06 / 2014$ & $26 / 06 / 2014$ & 14 & $\checkmark$ & $\checkmark$ & $\checkmark$ & $\checkmark$ & $\checkmark$ & $\checkmark$ & $\checkmark$ & $\checkmark$ & $\checkmark$ & $\begin{array}{l}\text { La documentación } \\
\text { es conforme }\end{array}$ \\
\hline 40 & 1040 & $13 / 06 / 2014$ & $27 / 06 / 2014$ & 14 & $\checkmark$ & $\checkmark$ & $\checkmark$ & $\checkmark$ & $\checkmark$ & $\checkmark$ & $\checkmark$ & $\checkmark$ & $\checkmark$ & $\begin{array}{l}\text { La documentación } \\
\text { es conforme }\end{array}$ \\
\hline
\end{tabular}

\section{Documentación Soporte:}

Expedientes de clientes

Reporte de seguimiento de enero a junio 2014

\section{ANEXO C: CONCLUSIÓN DE LA PRUEBA:}

\section{Controles 3.1 y 5.1: Efectivo}

En base al procedimiento de revisión documentaria, se concluye que el control se encuentra operando eficazmente ya que en los casos revisados se ha cumplido con las actividades diseñadas para mitigar el riesgo de incumplimiento regulatorio.

\section{Control 4.1: Inefectivo}

En base al procedimiento de revisión documentaria, se concluye que el control no se encuentra operando eficazmente ya que se han detectado casos en los cuales no se envió la carta de extensión de plazo a los clientes.

\section{Causa:}

El analista de atención al cliente obtiene un reporte del sistema y lo filtra mediante una macro en Excel para determinar los casos a los cuales se le enviará carta de extensión de plazo ya que se considera que la evaluación requerirá mayor tiempo. Al comparar el reporte generado del sistema vs. El filtrado por el analista se detectaron diferencias las cuales se deben a que dicho aplicativo Excel no está considerando el tipo de evento de reclamo relacionado a "cargos no autorizados en tarjetas de débito".

Si bien, ello no afecta la respuesta final del reclamo, es responsabilidad del área de atención de reclamos el envío de dicha comunicación. 


\section{Efecto:}

- $\quad$ Se obtiene un riesgo de observación y/o amonestación por parte de la SBS, sin embargo, los casos escalados a INDECOPI si reflejarían una sanción económica inmediata.

- $\quad$ Impacto en la reputación del banco por mala percepción del servicio brindado lo cual se plasmaría en disminución de cartera de clientes y por ende en beneficios económicos.

- $\quad$ Incapacidad de lograr los objetivos estratégicos del área y del

banco

Riesgo: ALTO

Nivel de Observación: Nivel 4 (Desviación de regulación y políticas con impacto en la reputación)

\begin{tabular}{|c|c|c|c|c|}
\hline \multicolumn{5}{|c|}{ NIVELES DE CLASIFICACIÓN DE OBSERVACIONES } \\
\hline Nivel & Nivel General & Riesgo Regulatorio & $\begin{array}{c}\text { Desviación de } \\
\text { políticas }\end{array}$ & $\begin{array}{c}\text { Riesgo } \\
\text { Reputacional }\end{array}$ \\
\hline Nivel 4 & $\begin{array}{l}\text { Debilidad del control } \\
\text { respecto a desviación } \\
\text { del marco regulatorio } \\
\text { requiere acción } \\
\text { inmediata de la } \\
\text { gerencia y planes de } \\
\text { acción correctivos } \\
\text { para alinearse a la } \\
\text { normativa vigente. }\end{array}$ & $\begin{array}{l}\text { Debilidad en el } \\
\text { control que puede } \\
\text { resultar en acciones } \\
\text { de regulador que } \\
\text { afectarían a la entidad } \\
\text { o jurisdicción local y } \\
\text { puede relacionarse a } \\
\text { violación de políticas } \\
\text { o procedimientos. }\end{array}$ & $\begin{array}{l}\text { Políticas y } \\
\text { procedimientos del } \\
\text { negocio o de } \\
\text { productos, } \\
\text { inapropiado diseño de } \\
\text { las políticas, o fallas } \\
\text { en la eficacia } \\
\text { operativa de una } \\
\text { política puede generar } \\
\text { fallas en los controles. }\end{array}$ & $\begin{array}{l}\text { Riesgo } \\
\text { reputacional } \\
\text { debido a una } \\
\text { actividad que } \\
\text { puede resultar en } \\
\text { publicidad negativa } \\
\text { del banco. La } \\
\text { debilidad en el } \\
\text { control puede } \\
\text { existir a entidad lo } \\
\text { cual puede generar } \\
\text { un impacto } \\
\text { negativo en la } \\
\text { reputación del } \\
\text { banco. }\end{array}$ \\
\hline
\end{tabular}

Fuente: Elaboración Propia 
Tabla 5.144 - Formato de Prueba de Eficacia de Controles (PEC) $\mathrm{N}^{\circ} 6.1$

PEC 6.1 - PRUEBA EFICACIA DE CONTROLES

AI 001 - Retail - Atención de Reclamos - Perú

\section{Riesgo:}

Administración inapropiada y atrasada de los reportes de quejas trimestrales regulatorios expone al banco a sanciones del regulador.

\section{Control clave mitigante del riesgo:}

6.1 Trimestralmente, el supervisor de atención al usuario elabora reportes de gestión estadístico de los reclamos recibidos en el periodo y envía al área de contabilidad para que lo remitan a la SBS. Este control se encuentra evidenciado a través de los reportes trimestrales en comité de gerencia de atención de reclamos y el archivo de envío a la SBS.

\section{Objetivo de la prueba de eficacia operativa}

Validar que el área de reclamos tiene un mecanismo para asegurar la apropiada administración de la generación, divulgación y entrega de reportes regulatorios

\section{ANEXO I: PRUEBAS DE EFICACIA DE CONTROLES}

\section{Pasos preliminares del testing:}

La población de reportes regulatorios (reporte 24) enviado a la SBS incluido en el período auditado está compuesto por dos trimestres (cuarto trimestre del año 2013 y el primer trimestre de 2014). Por lo tanto, ambos reportes serán evaluados siguiendo las siguientes etapas:

1. Solicitar la información estadística de reclamos y quejas incluidas en los reportes regulatorios (reporte 24) para los dos trimestres seleccionados. Adicionalmente, solicite la carga del archivo de registro después de enviar esta información a través de SUCAVE y verificar que la información ha sido enviada dentro de los quince días después de la finalización del trimestre. Para cada reporte 24, solicite el cuestionario terminado durante el proceso de generación de este reporte y verifique que ha sido oportunamente completado y firmado.

2. Solicite la carta enviada al regulador con el reporte 24 y verifique que ha sido oportunamente enviado (dentro de los quince días después de terminado el trimestre) y verifique que está firmado por el responsable del área de servicio al cliente. 
3. Realice una visita in situ con el objeto de revisar el proceso de generación del reporte 24 y verifique que los controles definidos por el área (cuestionario y procedimientos) son usados para asegurar la correcta

4. Verifique que la información enviada a través del módulo SUCAVE, así como la información incluida en la carta enviada al regulador local (SBS) y la información publicada en la página Web coincida en cada trimestre. Esta prueba será ejecutada en dos partes:

a. Compare el reporte 24 incluido en la carta enviada a la SBS versus el reporte 24 a través de SUCAVE

b. Compare el reporte 24 enviado a SUCAVE versus la información publicada en la página Web del banco

Nota: Para realizar la segunda prueba, el reporte publicado en la página Web del banco será reconstruida considerando el reporte 24 enviado a la SBS a través de SUCAVE

5. Solicite el reporte trimestral de administración terminado después de cada trimestre y verifique que, entre otros aspectos incluya:

a. Que los datos consignados calcen con el reporte 24

b. Que los datos consignados calcen con los publicados en la página web

ANEXO II: RESUMEN DE LA REVISIÓN DOCUMENTARIA
\begin{tabular}{|l|c|c|c|c|c|c|}
\hline \multicolumn{1}{|c|}{ Documento a revisar } & $\mathbf{4 a}$ & $\mathbf{4 b}$ & $\mathbf{5 c}$ & $\mathbf{5 d}$ & \multicolumn{1}{c|}{ Comentarios } \\
\hline 1. & Reporte 1er trimestre & $\checkmark$ & $\checkmark$ & NA & NA & La documentación es conforme \\
\hline 2. & Reporte 2do trimestre & $\checkmark$ & $\checkmark$ & NA & NA & La documentación es conforme \\
\hline 3. & Reporte 1er trimestre gerencial & NA & NA & $\checkmark$ & $\checkmark$ & La documentación es conforme \\
\hline 4. & Reporte 2do trimestre & NA & NA & $\checkmark$ & $\checkmark$ & La documentación es conforme \\
\hline
\end{tabular}

\section{Documentación Soporte:}

$\checkmark$ Reportes SBS 1er y segundo trimestre 2014

$\checkmark$ Reportes gerenciales 1er y segundo trimestre 2014

$\checkmark$ Página web 


\section{ANEXO C: CONCLUSIÓN DE LA PRUEBA:}

\section{Control 6.1: Efectivo}

En base al procedimiento de revisión documentaria, se concluye que el control se encuentra operando eficazmente ya que en los casos revisados se ha cumplido con las actividades diseñadas para mitigar el riesgo de incumplimiento regulatorio.

Fuente: Elaboración Propia

\subsubsection{Desarrollo de Recomendaciones con valor agregado}

Las observaciones y recomendaciones de basan en los siguientes atributos:

$\checkmark$ Criterio: Estándares, medidas o supuestos utilizados al hacer una evaluación y verificación.

$\checkmark$ Condición: La evidencia, los hechos que el auditor interno encuentra durante la realización de su trabajo.

$\checkmark$ Causa: La razón de la diferencia entre las situaciones esperadas y las reales

Efecto: El riesgo o exposición a la que se encuentra la organización o terceros debido a que la condición no coincide con el criterio (el impacto de la diferencia). Para determinar el grado de riesgo o exposición el auditor interno tiene en cuenta el efecto de las observaciones y recomendaciones puedan tener sobre las operaciones y los estados financieros de la organización.

Las observaciones y recomendaciones pueden incluir logros obtenidos por el cliente del trabajo, problemas relacionados e información soporte. (IAI. Consejo para la práctica $\left.\mathrm{N}^{\circ} 2410-1\right)$.

Aterrizando los criterios establecidos en el consejo para la práctica 2410-1, y complementándolos a fin de poder generar valor agregado para la organización podemos afirmar que el valor real de un trabajo de auditoría no proviene de la identificación de los hallazgos, sino del desarrollo de planes de acción recomendaciones) de alto impacto, significativos y aplicables. Las recomendaciones tienen que ser simples, pero efectivas, no se debe suministrar soluciones que no puedan ser implementas por el alto costo o lo sofisticado de las opciones propuestas. 
Igualmente, peligroso representa el brindar consejos de solución que no presenten una alternativa real de implementación, que represente simples mandatos o instrucciones de corrección.

Los departamentos de auditoría de alto rendimiento alinean sus medidas de desempeño con las expectativas y valores de las partes interesadas y con sus propios objetivos y plan estratégico, las medidas de éxito generalmente incluyen asignaciones completadas, cantidad de hallazgos, número recomendaciones implementadas, puntos recurrentes incluidos en el informe, tiempo de duración los proyectos y nivel de satisfacción de los clientes. Para mejorar el desempeño, tenemos que mejorar la calidad del resultado del trabajo.

\section{Aspectos relevantes:}

$\checkmark$ Las recomendaciones deben enfocarse en curar la enfermedad en vez de tratar los síntomas (por ejemplo atacar la raíz del problema, en vez de los aspectos superficiales).

$\checkmark$ Las recomendaciones deben ser tan específicas como sea posible, para evitar malos entendidos en el momento de implementar las acciones que deben ser tomadas.

Las acciones deben ser realizables, esto es que el costo y los esfuerzos envueltos en la implementación deben ser conmensurables con el valor derivado de las acciones.

Las acciones deben ser medibles de tal forma que los dueños del proceso y los auditores pueden supervisar el progreso para asegurarse que las acciones serán implementadas oportunamente.

$\checkmark$ Si el Estatuto de Auditoria o la cultura organizacional apoyan la colaboración con los dueños del proceso, puede ser muy beneficioso codesarrollar las acciones de mejoras junto con los dueños de los procesos, Estas soluciones desarrolladas de común acuerdo poseen una mayor probabilidad de implementación exitosa, debido a que los dueños de los procesos contribuyeron en la determinación de mismas, lo cual disipa cualquier atmosfera de confrontación que se origina cuando se discuten las recomendaciones. (Nahun Freundt, 2012). 
Considerando lo descrito con anterioridad, la metodología establece efectuar las recomendaciones en base la técnica de Root Cause o raíz del problema con lo que se pretende es realizar un análisis que permita al equipo de auditoría, en conjunto con el negocio, entender las razones por que las excepciones ocurrieron. Una prueba adicional puede requerirse para determinar la naturaleza de la excepción del control. Los miembros del equipo de auditoría deben determinar el impacto de la operatividad ineficaz de los controles clave.

El análisis de la raíz del problema es una técnica que intenta identificar y corregir las razones que llevaron a un resultado no deseado. La meta es determinar ¿Que sucedió?, ¿Por qué se dio? Y que se podría hacer para evitar que vuelva a suceder.

Para ello es necesario confirmar las observaciones con los dueños del proceso y se debe enfocar la discusión en poner énfasis en acordar la existencia de la debilidad, identificar si existe algún control complementario que también pueda mitigar el riesgo y explicarles por qué, a criterio del auditor, los controles no se encuentran operando adecuadamente.

\subsubsection{Raíz del problema e Impacto potencial}

En base a lo descrito en la sección anterior, previo al desarrollo de las recomendaciones se debe identificar la causa y el impacto de la debilidad en el control:

\section{Causa:}

El analista de atención al cliente obtiene un reporte del sistema y lo filtra mediante una macro en Excel para determinar los casos a los cuales se le enviará carta de extensión de plazo ya que se considera que la evaluación requerirá mayor tiempo. Al comparar el reporte generado del sistema vs. El filtrado por el analista se detectaron diferencias las cuales se deben a que dicho aplicativo Excel no está considerando el tipo de evento de reclamo relacionado a "cargos no autorizados en tarjetas de débito".

Si bien, ello no afecta la respuesta final del reclamo, es responsabilidad del área de atención de reclamos el envío de dicha comunicación.

\section{Efecto:}


- Se obtiene un riesgo de observación y/o amonestación por parte de la SBS, sin embargo, los casos escalados a INDECOPI si reflejarían una sanción económica inmediata.

- Impacto en la reputación del banco por mala percepción del servicio brindado lo cual se plasmaría en disminución de cartera de clientes y por ende en beneficios económicos.

- Incapacidad de lograr los objetivos estratégicos del área y del banco

\section{Recomendación:}

Recomendamos revisar a detalle, coordinando con el equipo global de desarrollo de TI, la macros que filtra y genera las cartas de extensión de plazo. Así mismo es necesario realizar una validación preventiva de los casos filtrados en este aplicativo mediante la conciliación de las cantidades de reclamos registrados versus los filtrados por la macros a fin de obtener suficiente seguridad que todas las cartas que se tiene conocimiento superarán el plazo regulatorio serán enviadas a los clientes dentro de dicho tiempo.

\subsubsection{Categorización de la observación}

En basa al análisis realizado, y habiendo identificado la razón por la cual se generó la debilidad en el control y considerando que si bien constituye un riesgo crítico que impacta la reputación y constituye una posible sanción del regulador, su subsanación no constituye un proceso complejo ya que el área de atención de reclamos cuenta con los recursos suficientes que destinará a ejecutar un control complementario a fin de evitar que no se contemplen todos los casos que superen el plazo regulatorio.

Por tanto, representa una debilidad de nivel 4 ya que la desviación se dio a nivel proceso. Ver tabla de Nivel de observaciones en el ANEXO $\mathrm{N}^{\circ} 5$ - Tabla de niveles de observaciones. 


\subsubsection{Planes de acción planteados por el área de Atención de Reclamos}

Tabla 5.155 - Planes de acción planteados por el área de atención de reclamos.

\section{Dueño del proceso: Gerente 1 \\ Responsable del levantamiento: Supervisor 1}

Fecha de la observación: 18.09.2014

Fecha de compromiso: 31.12 .2014

Fecha de validación de observación: 15.01.2015.

a) La macro utilizada para monitorear el anticuamiento de reclamos será revisada para asegurar que todos los tipos de reclamos se capturen. Pendiente la validación de auditoría interna.

Responsable: Supervisor 1

Fecha de cumplimiento: 31.12.2014

b) Se solicitará el apoyo del equipo regional de desarrollo para que validen y realicen pruebas en la macro de acuerdo a las políticas regionales del uso de aplicativos.

Responsable: Supervisor 1

Fecha de cumplimiento: 31.12 .2014

Fuente: Elaboración Propia

\subsection{Elaboración del reporte de auditoría interna}

Para la elaboración del reporte de auditoría, se debe considerar los consejos para la práctica establecidos en el marco profesional para la práctica profesional de la auditoría interna.

El auditor interno necesita actuar con cautela a la hora de comunicar incumplimiento de leyes, regulaciones y otros asuntos legales. (IAI. Consejo para la práctica $\left.\mathrm{N}^{\circ} 2400-1\right)$.

Las observaciones y recomendaciones de basan en los siguientes atributos: 
- Criterio: Estándares, medidas o supuestos utilizados al hacer una evaluación y verificación.

- Condición: La evidencia, los hechos que el auditor interno encuentra durante la realización de su trabajo.

- Causa: La razón de la diferencia entre las situaciones esperadas y las reales

- Efecto: El riesgo o exposición a la que se encuentra la organización o terceros debido a que la condición no coincide con el criterio (el impacto de la diferencia). Para determinar el grado de riesgo o exposición el auditor interno tiene en cuenta el efecto de las observaciones y recomendaciones puedan tener sobre las operaciones y los estados financieros de la organización.

Las observaciones y recomendaciones pueden incluir logros obtenidos por el cliente del trabajo, problemas relacionados e información soporte. (IAI. Consejo para la práctica $\left.\mathrm{N}^{\circ} 2410-1\right)$.

\section{Calidad de las comunicaciones}

Las comunicaciones deben ser precisas, objetivas, claras, concisas, constructivas y oportunas. (IAI. Consejo para la práctica ํ2 2420-1).

\section{Difusión de resultados}

El director de auditoría debe revisar y aprobar la comunicación final del trabajo antes de su emisión y decidir a quiénes y cómo será distribuida dicha comunicación. EL director de auditoría tiene la responsabilidad final a pesar que delegue estas funciones. (IAI, 2013 Consejo para la práctica $\left.N^{\circ} 2440-1\right)$.

Por otro lado, también deben considerarse los lineamientos de establecidos por la SBS ya que define específicamente el contenido mínimo de los informes y la obligación de reportarlos periódicamente al directorio:

\section{Contenido mínimo de los informes}

Los informes de la UAI deberán contener, por lo menos, la siguiente información:

a. Objetivo y alcance de la evaluación; 
b. Evaluación de la situación de la actividad u operación a la fecha del informe, identificando los riesgos detectados y su impacto en la empresa;

c. Observaciones y recomendaciones formuladas, independientemente de que estén subsanadas o no al cierre del informe, indicando el estado en el que se encuentran;

d. Nombre del funcionario responsable de la evaluación; y,

e. Fecha de inicio y término de la evaluación. (Resolución SBS 11699, 2008, Artículo $\mathrm{N}^{\circ}$ 22)

El formato establecido por la casa matriz ha adoptado los lineamientos establecidos en las normas del instituto de auditores internos así como el contenido mínimo exigido por la regulación local. La estructura consta de las siguientes secciones:

$>$ Resumen Ejecutivo: El resumen ejecutivo define el objetivo y alcance de la evaluación. Así mismo, se especifica el cumplimiento de la regulación local y las normas del instituto de auditores internos (IAI). Por otro lado cuenta con un resumen de la evaluación efectuada y los procedimientos realizados.

$>$ Sección A - Detalle de observaciones: Contiene detalle de las observaciones.

> Sección B - Evaluación de la Matriz de Riesgo de Negocio (MRN): Se adjunta un resumen de las observaciones alineadas a riesgos identificados por la misma gerencia.

Sección C - Requerimientos regulatorios: Refiere a un resumen de la regulación local aplicable al proceso evaluado.

> Sección D - Información complementaria del negocio: Describe información del negocio así como del enfoque, alcance y equipo responsable de auditoría.

\section{Sección E - Definiciones}

El informe final emitido para la auditoría ilustrada en el presente proyecto, correspondiente a la evaluación del proceso de atención de reclamos ha tenido como calificación de "oportunidad de mejora" en base a los criterios establecidos en el ANEXO $\mathrm{N}^{\circ} 5$ - Tabla de niveles de observaciones, en dónde se precisa que los 
resultados de la auditoría indican que a pesar que se cuenta con suficiente aseguramiento en el diseño y efectividad operativa de los controles para mitigar o administrar los riesgos a los cuales el proceso auditado se encuentra expuesto, debe prestarse atención en adecuar cierto control(es) de cierta(s) área(s).

El reporte de auditoría se encuentra adjunto y detallado en el ANEXO $\mathrm{N}^{\circ} 6-$ Reporte de auditoría interna.

\subsection{Presentación de resultados al directorio}

La UAI deberá presentar al comité de auditoría o directorio, todos los informes que elabore en cumplimiento de sus funciones. Dicho órgano evaluará los informes respectivos a más tardar en la sesión inmediata siguiente a su presentación. La oportunidad en que dicho órgano tome conocimiento de los informes, las decisiones que al respecto se adopten y el seguimiento de las medidas correctivas, deberá constar en el Libro de Actas respectivo. (Resolución SBS 11699, 2008, Artículo N²0).

El banco ha establecido contar con sesiones de directorio cuatrimestrales en

dónde el gerente de auditoría, a manera de resumen, presenta los resultados de las evaluaciones realizadas en el periodo así como el seguimiento de las observaciones que aún no han sido subsanadas.

\subsection{Documentación}

La UAI deberá mantener un archivo conteniendo los informes elaborados, papeles de trabajo y comunicaciones informando el resultado de sus exámenes a las diferentes unidades de la empresa, así como la documentación sustentadora de los mismos. Dicha información deberá estar a disposición de la Superintendencia, los auditores externos y, de ser el caso, de las empresas clasificadoras de riesgo, cuando así lo requieran. (Resolución SBS 11699. Artículo N²0).

En lo que respecta a la documentación, el banco cuenta con un aplicativo online informático a través del Lotus Notes el cual permite alojar los resultados de la auditoría. Su función es básicamente ser un repositorio de documentos soporte de la ejecución del proceso de auditoría así como los resultados de la misma. 
Cabe mencionar que en lo referente a la aplicación de la ley de protección de datos personales, no se incluye ningún tipo de información confidencial de clientes en la documentación del proceso de auditoría.

Los documentos que serán alojados en dicho repositorio con su respectiva codificación, se encuentran detallados en el ANEXO N 7 - Documentación

\subsection{Seguimiento de implementación de mejoras en el área de atención de reclamos}

La tarea de monitoreo y seguimiento de observaciones se ejecuta mediante la programación de actividades de levantamiento de situaciones, con fecha posterior a la implementación de la mejora del proceso.

La responsabilidad de atender e implementar las observaciones, aspectos de mejora y recomendaciones recae en el Vicepresidente o Gerente del área o proceso o producto auditado; asimismo, será responsable de sustentar y remitir al área de Auditoria Interna la documentación que sustente la implementación de las observaciones, en el plazo establecido.

Por otro lado, la metodología establecida por el banco define realizar procedimientos de auditoría para validar que el proceso se ha adecuado a las recomendaciones efectuadas por el área de auditoría interna. 


\section{CONCLUSIONES}

- La gestión de riesgos es un componente fundamental del gobierno corporativo siendo responsabilidad de la gerencia establecer y operar el enfoque de gestión de riesgos en nombre del directorio. La gestión de riesgos para toda la empresa aporta múltiples beneficios como resultado de su enfoque estructurado, coherente y coordinado. El rol principal de la auditoría interna en relación con ERM debe ser brindar aseguramiento a la dirección y al consejo de administración en cuanto a la eficacia de la gestión de riesgos.

- La auditoría Interna es una actividad independiente y objetiva de aseguramiento y consulta concebida para agregar valor y mejorar las operaciones de una organización, ayuda a las instituciones a cumplir con sus objetivos, evalúa y mejora la eficacia de los procesos de gestión de riesgos control y gobierno implementados por las organizaciones, mediante la aplicación de procesos y técnicas con un enfoque sistemático y disciplinado. Los auditores internos para el desempeño de su labor deben reunir los conocimientos, aptitudes y competencias adecuadas a través de la capacitación y educación continuada.

- Las expectativas de los stakeholders representan una consideración importante a tomarse en cuenta en la ejecución de una auditoría basada en riesgos ya que la formulación de recomendaciones se enfocarán en generar valor agregado para la organización que permita el logro de los objetivos.

- Sobre la base del desarrollo de la auditoría con enfoque en riesgos, se confirmó que mediante el desarrollo de esta metodología se cuenta con un mayor nivel de aseguramiento al contar con un enfoque sistemático de los riesgos relacionados al proceso de atención de reclamos. Así mismo, se contribuye a que la organización identifique y gestione adecuadamente los distintos tipos de riesgos a los cuales se encuentra expuesta. 
- En el desarrollo de este trabajo, la hipótesis del proyecto ha quedado confirmada, pues efectivamente se ha comprobado que desarrollando la metodología ABR (Auditoría Basada en Riesgos) se obtiene un mayor nivel de aseguramiento al contar con un enfoque sistemático de riesgos en múltiples tipologías. Por otro lado, se amplía el alcance de riesgos evaluados y se pudo validar que el proceso de gestión de riesgos funciona eficazmente a pesar de identificar una desviación en el control de plazos de atención de reclamos.

En suma, los riesgos descritos en este proyecto se encuentran gestionados en un nivel aceptable, lo cual permitirá a la organización alcanzar sus objetivos 


\section{RECOMENDACIONES}

- Para desarrollar la actividad de auditoria interna, es aconsejable la aplicación e implementación de las normas internacionales para el ejercicio de la función auditoria interna emitidas por el Instituto global de Auditores internos, la aplicación de un método de evaluación de control interno que incluya los procesos de gestión de riesgos, además de mantener una educación continua de los auditores internos para asegurar el buen desempeño de su labor.

- Siempre deben tenerse en consideración las expectativas de los stakeholders y el cumplimiento de los objetivos estratégicos de la organización como punto de partida en la ejecución de una auditoría basada en riesgos.

- Deben realizarse por cada auditoría talleres de concientización a fin de poder alinear las expectativas de la auditoría y que los dueños del proceso asuman la responsabilidad y compromiso durante el proceso de la auditoría basada en riesgos.

- Se sugiere continuar utilizando el modelo de control interno basado en Gestión de Riesgo de Negocio (ERM) como herramienta de gestión de riesgos, con el objetivo de proporcionar una seguridad razonable del cumplimiento de los objetivos institucionales, así mismo el consejo de administración, la dirección y el resto del personal de una entidad deben comprometerse a que exista cultura de riesgos y observar los elementos siguientes que integran este modelo: ambiente interno, establecimiento de objetivos, identificación de eventos, evaluación de riesgos, respuesta a los riesgos, actividades de control, información y comunicación y supervisión.

- Para el desarrollo de la auditoría del proceso de atención de reclamos, el banco deberá considerar los riesgos del proceso, evaluar el control interno con base al sistema de gestión integral de riesgos, aplicar pruebas sustantivas, de cumplimiento 
y para realizar una adecuada auditoria se sugiere considerar los siguientes pasos: pre-auditoria, planificación, ejecución del trabajo, informe, supervisión y seguimiento.

- Optimizar el monitoreo de cumplimiento del plazo regulatorio, deben establecerse mecanismos internos que permitan verificar y supervisar dicha actividad de control. Para ello, el supervisor debe establecer una validación periódica del proceso, debe verificarse que todos los casos se estén contemplando en el envío de extensión de plazos. 


\section{GLOSARIO}

\section{Riesgo}

Es la contingencia que un evento ocurra y afecte de forma desfavorable al logro de objetivos en una organización.

Posibilidad de la ocurrencia de un evento por causas internas o externas. Entre los eventos externos están los económicos, medioambientales, políticos, sociales o tecnológicos; entre los internos se encuentran infraestructura, personal, procesos y tecnología.

\section{Riesgo Inherente}

Es el que enfrenta una organización en ausencia de acciones por parte de la dirección.

\section{Riesgo Aceptado}

Es la cantidad de riesgo que una institución está dispuesta aceptar para la consecución de sus objetivos, ya que es imposible que todos los riesgos sean cubiertos. Es el constituido por la dirección bajo la supervisión y control del consejo de administración o su equivalente, para establecer los objetivos de la institución, y se pude expresar como el equilibrio entre crecimiento, riesgo y rendimiento.

\section{Riesgo Residual}

Es lo que queda de riesgo después que la dirección haya desarrollado respuestas a estos, puede definirse con la ecuación:

Riesgo total (-) controles $=$ Riesgo residual

\section{Tolerancia al riesgo}

Es la medición de la desviación del riesgo aceptado para la consecución de los objetivos de la institución dentro de parámetros establecidos, sirve de indicador en la verificación y aseguramiento del cumplimiento de objetivos. 


\section{Matriz de Riesgo}

Es la representación gráfica de los riesgos, resultado de la finalización del proceso de evaluación y gestión de riesgo empresarial. Es preparada por la administración de Ia entidad quien es la responsable de la gestión del riesgo del negocio.

\section{Evento}

Es la consecución de un acontecimiento que puede afectar de manera positiva o negativa en las operaciones de la empresa. Los eventos positivos pueden agregar valor a la empresa a diferencia de los negativos, se pueden dar por medio de fuentes internas y externas.

\section{Factores de Riesgo}

Los factores de riesgo son manifestaciones o características medibles y observables de un proceso que tienden a aumentar la "exposición" a que un riesgo se materialice, y tiene las siguientes características:

- Acordes con la naturaleza del proceso

- Conllevan riesgos potencialmente reales y críticos del proceso

- Se deben evaluar como absoluto (eliminar todos los controles)

La forma más simple de identificar los factores de riesgo es pensar en las situaciones o aspectos que podrían provocar que el riesgo se materialice y el objeto del negocio no se logre.

\section{Probabilidad e impacto}

a. La probabilidad, es la posibilidad originada de la incertidumbre en la consecución del evento positivo o negativo, se pude clasificar como alta, media y baja.

b. El impacto, refleja el efecto por la materialización de la incertidumbre.

Los dos términos van interrelacionados para poder calificar el tipo de riesgo como alto, medio o bajo. 


\section{Calificación del Riesgo}

Después de haber determinado la probabilidad y el impacto del riesgo se procede a calificar el riesgo conforme a estos, puede ser calificado como alto medio y bajo, esto depende de su materialidad en términos económicos y a su incidencia.

\section{Respuesta a los Riesgos}

Es la manera en que se va a contrarrestar los riesgos ya sea evitarlos, compartirlos, reducirlos o aceptarlos.

\section{Evaluación de Riesgos}

La evaluación de riesgos es el proceso mediante el cual se identifican, analizan y valoran los medios de control diseñados para manejar y minimizar las posibilidades y errores o irregularidades que se producen y afectan la eficiencia, efectividad y economía en el manejo y use de los recursos asignados para la ejecución de las operaciones.

\section{Gestión de Riesgos}

La gestión de riesgos corporativos es un proceso efectuado por el consejo de administración de una entidad, su dirección y restante personal, aplicado en la definición de la estrategia y en toda la entidad y diseñado para identificar eventos potenciales que puedan afectar a la organización y gestionar sus riegos dentro del riesgo aceptado, proporcionando una seguridad razonable sobre el logro de objetivos.

\section{Gobierno Corporativo}

Describe el papel de personas a quienes se confía la supervisión, control y dirección de una entidad. Los encargados del gobierno corporativo son ordinariamente responsables de asegurar que la entidad logre sus objetivos, de la información financiera y de informar a las partes interesadas. Los encargados del gobierno corporativo incluyen a la administración solo cuando desempeña dichas funciones.

La combinación de procesos y estructuras implantados por el Consejo de Administración para informar, dirigir, gestionar y vigilar las actividades de la organización con el fin de lograr sus objetivos. 


\section{Auditoría Interna}

La auditoría interna es una actividad independiente y objetiva de aseguramiento y consulta, concebida para agregar valor y mejorar las operaciones de una organización. Ayuda a una organización a cumplir sus objetivos aportando un enfoque sistemático y disciplinado para evaluar y mejorar la eficacia de los procesos de gestión de riesgos, control y gobierno.

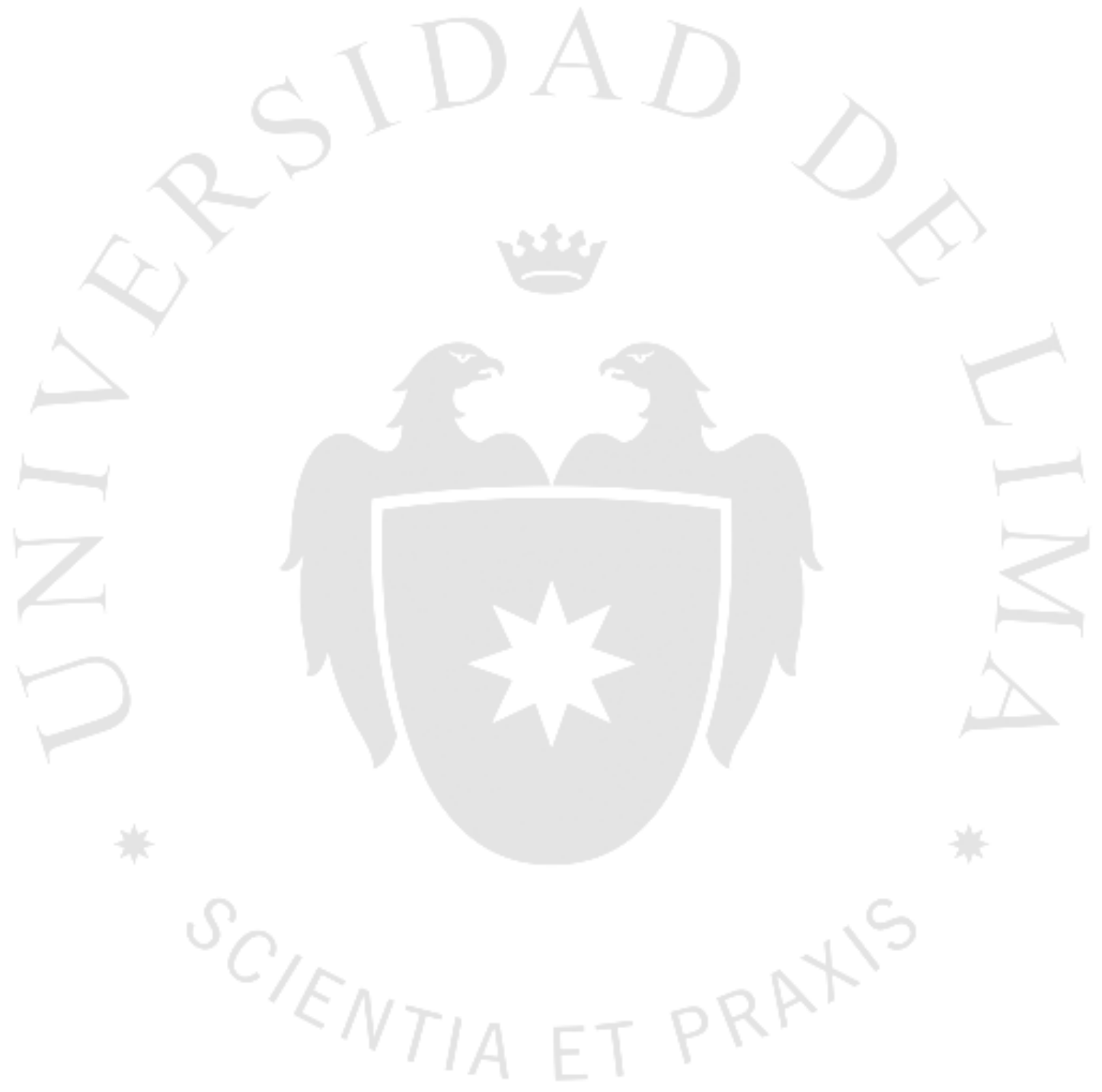




\section{REFERENCIAS}

Circular SBS N: G146-2009. (30 de diciembre del 2009). Servicio de Atención a los Usuarios. Superintendencia de Banca, Seguros y AFP: http://www.sbs.gob.pe

Committee of Sponsoring Organizations of the Treadway Commission. (2004). Guidance on Enterprise Risk Management - ERM - COSO. Recuperado de www.coso.org/-erm.htm

Frett, N. (Junio, 2012). Auditoría Basada en Riesgos: Una Guía Práctica para Alcanzar el éxito en su Gestión. Documento presentado en el curso de auditoría basada en riesgos, Lima, Perú.

Instituto de Auditores Internos de Argentina. (2004). Normas Sobre Desempeño. Recuperado de https://www.iaia.org.ar

PricewaterhouseCoopers. (15 de julio del 2013). Estudio sobre el estado de la profesión de auditoría interna. Recuperado de http://www.pwc.es/es/publicaciones/auditoria/informe-estado-profesionauditoria-interna-2013.jhtml

Resolución SBS No: 11699-2008, Reglamento de Auditoría Interna. (28 de noviembre del 2008). Recuperado del sitio de internet de la Superintendencia de Banca, Seguros y AFP: http://www.sbs.gob.pe

Resolución SBS Nº: 037-2008. (10 de enero del 2008). Reglamento de la Gestión Integral de Riesgos. Superintendencia de Banca, Seguros y AFP: http://www.sbs.gob.pe

The Internal Audit Institute. (Junio, 2009). The Role of Internal Auditing in Enterpreise-Wide Risk Management. Recuperado de https://na.theiia.org/standardsguidance/Public\%20Documents/PP\%20The\%20Role\%20of\%20Internal\%20Au diting\%20in\%20Enterprise\%20Risk\%20Management.pdf

The Internal Audit Institute. (2013) Normas Internacionales Para el Ejercicio Profesional de la Auditoría Interna. Madrid: Editorial Grafica Martin S.R.L.

Villanueva Chang J. (24 de noviembre del 2014). Plan Anual de Auditoría Interna Basado en Riesgos: Guía práctica para su implementación. [mensaje de un blog]. Recuperado de http://www.auditool.org/blog/auditoria-interna/1458-plananual-de-auditoria-basada-en-riesgos-guia-practica-para-su-implementacion 


\section{BIBLIOGRAFÍA}

Hernández, R., Fernández, C., y Baptista, P. (2010). Metodología de la investigación (5. ${ }^{\mathrm{a}}$ ed). México D.F: Editorial Mc Graw Hill. 


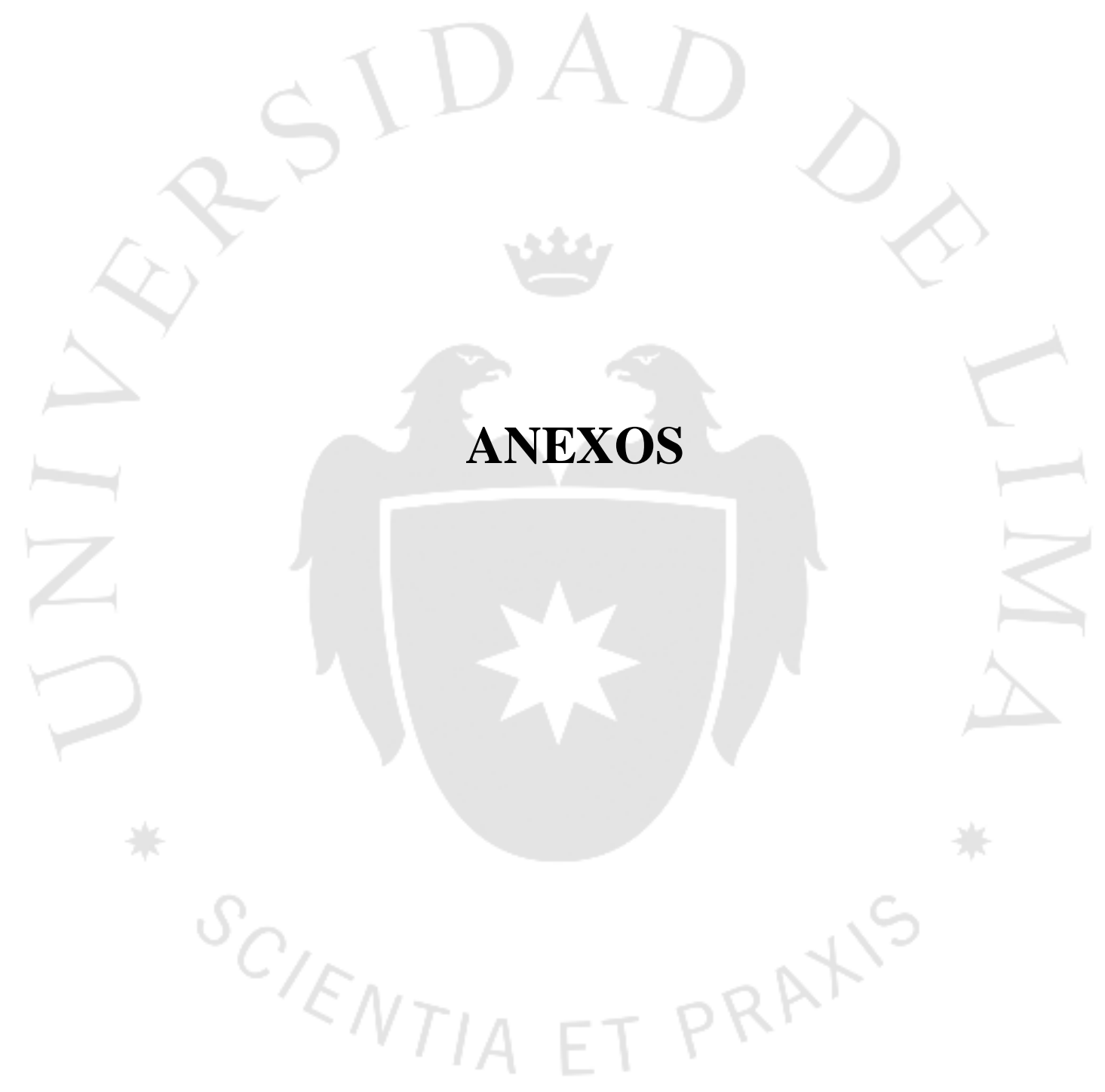




\section{ANEXO $\mathrm{N}^{\circ} 1$ - Memorándum requerimiento de información}

Memorándum Interno No AI-001/14

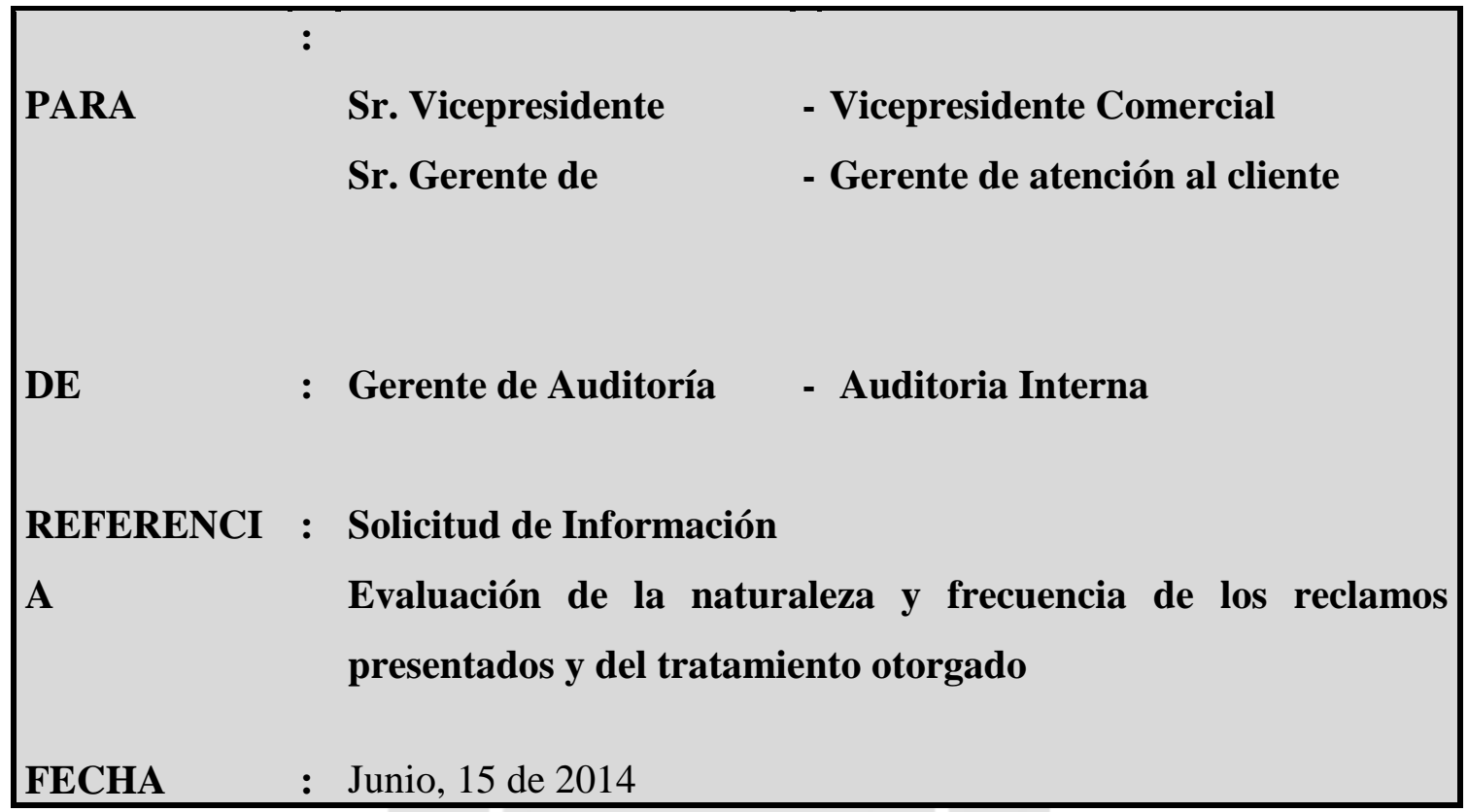

Cumpliendo con el Plan de Trabajo, les informo que el lunes 14 de julio daremos inicio a la auditoria de la referencia; motivo por el cual, apreciaremos nos brinden las facilidades del caso para el óptimo desempeño de dicha actividad.

Cabe resaltar que en el transcurso de la auditoria, estaremos solicitando al personal relacionado con el proceso evaluado, información y/o documentación, la misma que deberá ser atendida a la brevedad, dado que debemos culminar la auditoria en el plazo señalado; asimismo, estaremos realizando algunas consultas sobre los puntos en revisión.

A continuación detallamos, los objetivos, alcance, procedimientos de auditoria y plazos de elaboración del trabajo de campo e Informe.

\section{Objetivos de la evaluación:}

Los objetivos de la evaluación estarán orientados principalmente a: 
- Verificar el cumplimiento de las normas legales establecidas por la Superintendencia de Banca, Seguros y AFP.

- Evaluar el sistema de gestión integral de riesgos establecido y aplicado para la atención de reclamos y requerimientos de los clientes.

- Evaluar la calidad de la información (correcta y oportuna) que se presenta a la Superintendencia, particularmente la relacionada a los Anexos, en relación a los reclamos y requerimientos.

- Comprobar el cumplimiento de las políticas, normas y procedimientos establecidos por la Compañía.

- Efectuar seguimiento a la implementación de las recomendaciones de Auditoria (Interna, SBS y/o Externa) establecidas en revisiones anteriores.

\section{Alcance de la evaluación:}

Los temas indicados serán revisados de enero a junio del 2014.

\section{Procedimientos de Auditoria:}

Observación, indagación / entrevistas, inspección documentaria y revisión de muestras, a dicha fecha, de acuerdo a las circunstancias, disponibilidad de información y criterio del Auditor.

\section{Plazos de elaboración del trabajo de campo e Informes:}

- Reunión de inicio de la auditoría: 15.06.2014

- Fecha de entrega de información: 14.07.2014

- Inicio de la etapa de planeamiento: lunes 14.07.2014

- Finalización del trabajo de campo: miércoles 29.08.2014

- Entrega del Informe Preliminar: viernes 5.09.2014

- Entrega de comentarios al Informe Preliminar por parte del Gerente Comercial: miércoles 12.09.2014.

- Entrega de Informe Final a la Gerencia General: jueves 18.09.2014

\section{Documentación necesaria para el inicio de la evaluación:}

\section{Área Comercial:}


- Estadística presentada a la S.B.S. desde el 01.01 al 30.06, con sus respectivos sustentos.

- Reporte de reclamos y requerimientos al 30.06.2014 (en físico y excel).

- Anexos presentados a la SBS de enero a junio del 2014.

- Constancia del SUCAVE, de los Anexos del 2013 (1er y 2do. trimestre) y la carta a la SBS, de ser el caso.

- Reporte que detalle casos de reclamos presentados por el cliente a la S.B.S y PAU desde enero a junio 2014.

- Reporte de reclamos y requerimientos de clientes que ingresan por teléfono y correo electrónico.

- Control semanal estadístico para la administración de los tiempos de atención de requerimientos y reclamos de clientes (por área de atención.

- Procedimientos aplicados en el registro de reclamos y requerimientos de clientes que ingresan por teléfono. Informar los registros establecidos para su control y seguimiento.

- Totales de los Reclamos (por línea de negocio y categoría) - tipificados de acuerdo a nuestros procesos- acontecidos en los meses de enero a junio de 2014.

- Totales de Requerimientos y/o Pedidos, por línea de negocio desde enero a junio de 2014.

- Informes Gerenciales o de Gestión que detallan la cantidad de requerimientos y reclamos (por mes) desde enero a junio de 2014.

- Matriz de riesgos del proceso crítico "Consultas y Reclamos" o su equivalente correspondiente al área del Servicio al Cliente.

- Indicadores de Gestión (Monitoreo de Riesgos).

- Actas de sesión de Comité de Riesgos, en caso contengan información relacionada al tema evaluado.

Apreciaremos que la indicada información, nos sea alcanzada en su totalidad, a más tardar el lunes 14 de julio del 2014. La falta de alguna información no podremos considerarla para la auditoria, la misma que deberemos incluirla en el Informe como una limitación al alcance.

Atentamente, 
Gerente de Auditoria Interna

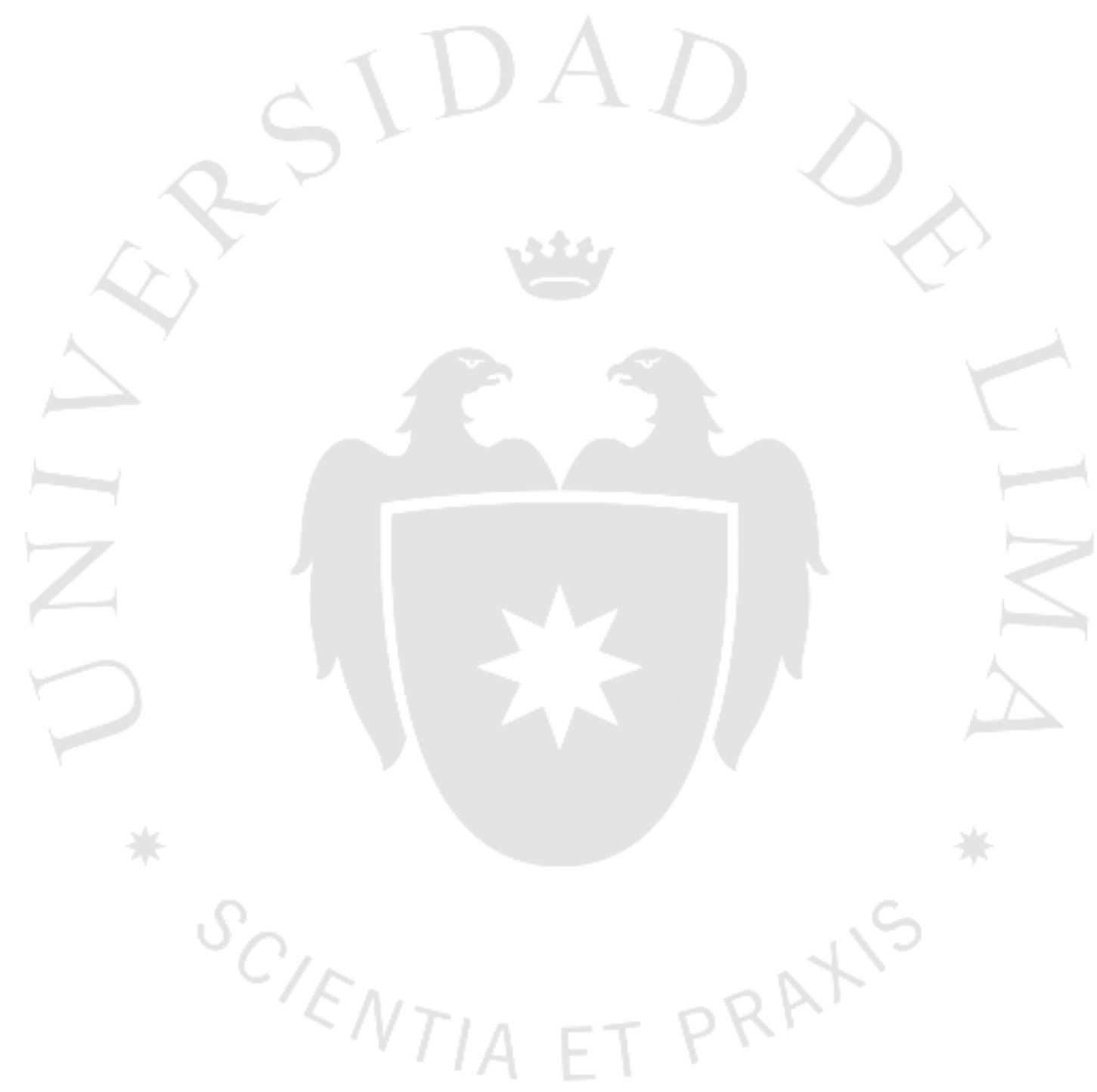


ANEXO $\mathrm{N}^{\circ} 2$ - Flujograma del proceso de atención de reclamos

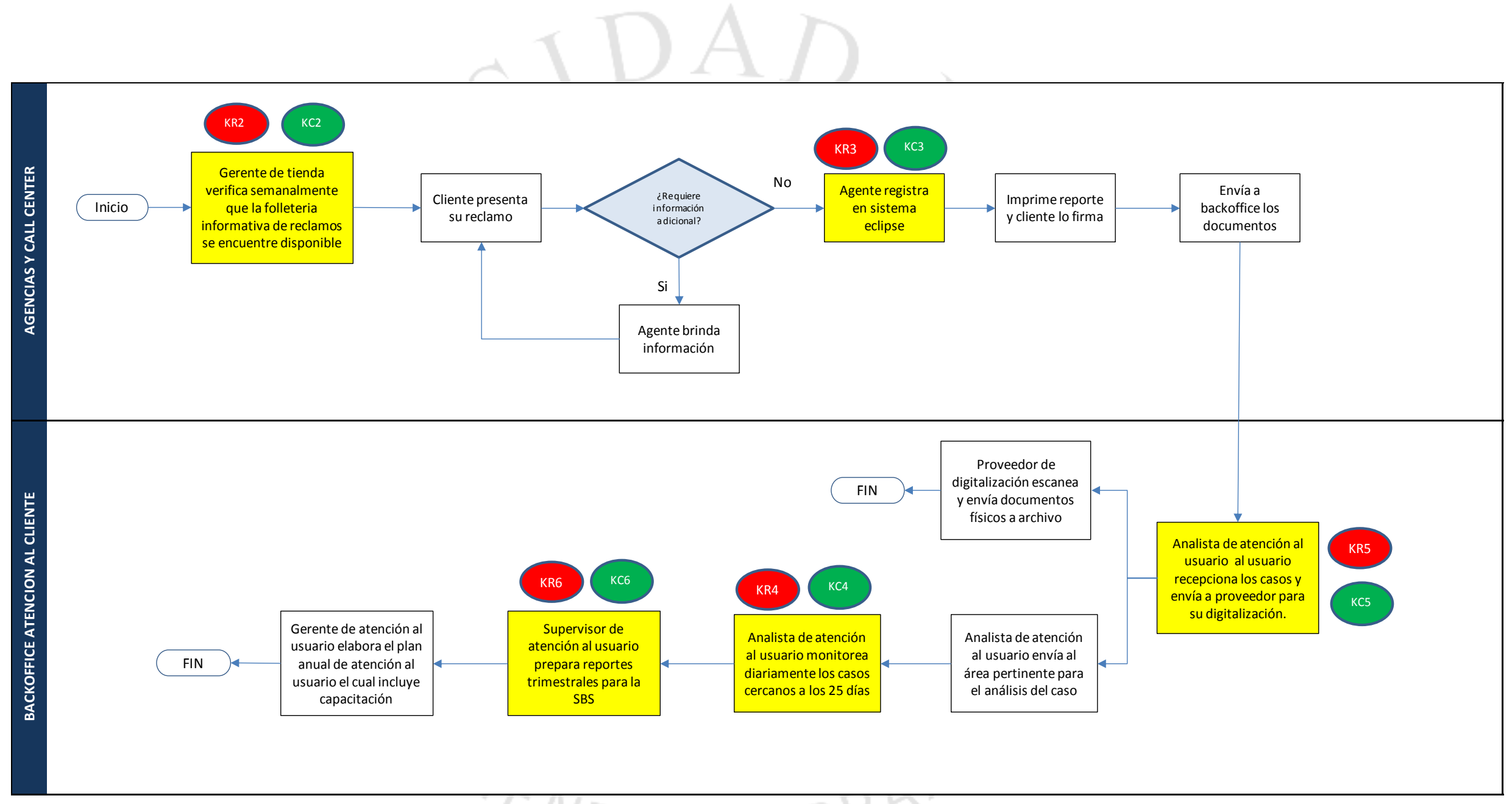




\section{Leyenda:}

\section{Key Risk}

Key Control

\section{Control Complementario}

\section{$\mathrm{CC}$}
Estructura organizacional inapropiada. Falta de segregación de funciones y entrenamiento inapropiado puede resultar en manejo inadecuado de las quejas del cliente y exposición del banco a análisis regulatorio

El área de quejas de clientes tiene un plan anual de entrenamiento vigente para empleados involucrados en las tareas de administración de quejas

Difusión inapropiada de la administración de quejas y procesos de presentación limitan el nivel de información disponible para los clientes y expone al banco a análisis regulatorios.

Información relacionada a la presentación de reclamos / quejas es exhibido en las instalaciones de las sucursales y en la página WEB del banco. El área de servicios del cliente es responsable de solicitar actualización de la información disponible. En las sucursales, la solicitud es enviada a través de email. En la página WEB del banco, la solicitud es solicitada por canales remotos a través de procesos de actualización de información de la página WEB.

Procesos inapropiados para registrar las quejas de clientes expone al banco a análisis regulatorios

El proceso de registro de quejas es ejecutado online en el sistema Eclipse. Para quejas presentadas en persona el cliente firma el reporte generado por el sistema conteniendo información de quejas. Para quejas presentadas por teléfono el registro es también ejecutado online y el reporte de quejas es entregado conforme a la especificación (vía email, e-mail, etc.). Los reportes son puestos a disposición de los clientes en cualquier localización de las sucursales.

Administración inapropiada y tardía de quejas de clientes expone al banco a análisis regulatorio El área de servicio al cliente está continuamente monitoreando los períodos de tiempo mediante reportes diarios de rastreo. Una nueva macro fue desarrollada para asegurar que toda clase de reclamos están siendo capturados por rastreos de antigüedad y reportes de generación.

Inapropiada administración de los archivos de quejas de los clientes expone al banco a análisis regulatorio 
Registros de quejas y disposición de la documentación es almacenada en el sistema repositorio de imagen del banco (Citidocs) y se comparten archivos digitales internos. El supervisor de servicios al consumidor ejecuta la validación mensual del sistema Citidocs y archivos físicos.

Administración inapropiada y atrasada de los reportes de quejas trimestrales regulatorios expone al banco a análisis regulatorios

El proceso de reporte regulatorio abarca una revisión ejecutada vía cuestionario con el objeto de asegurar la exactitud del reporte y entrega oportuna. 


\section{ANEXO N ${ }^{\circ} 3$ - Pruebas de Diseño de Controles}

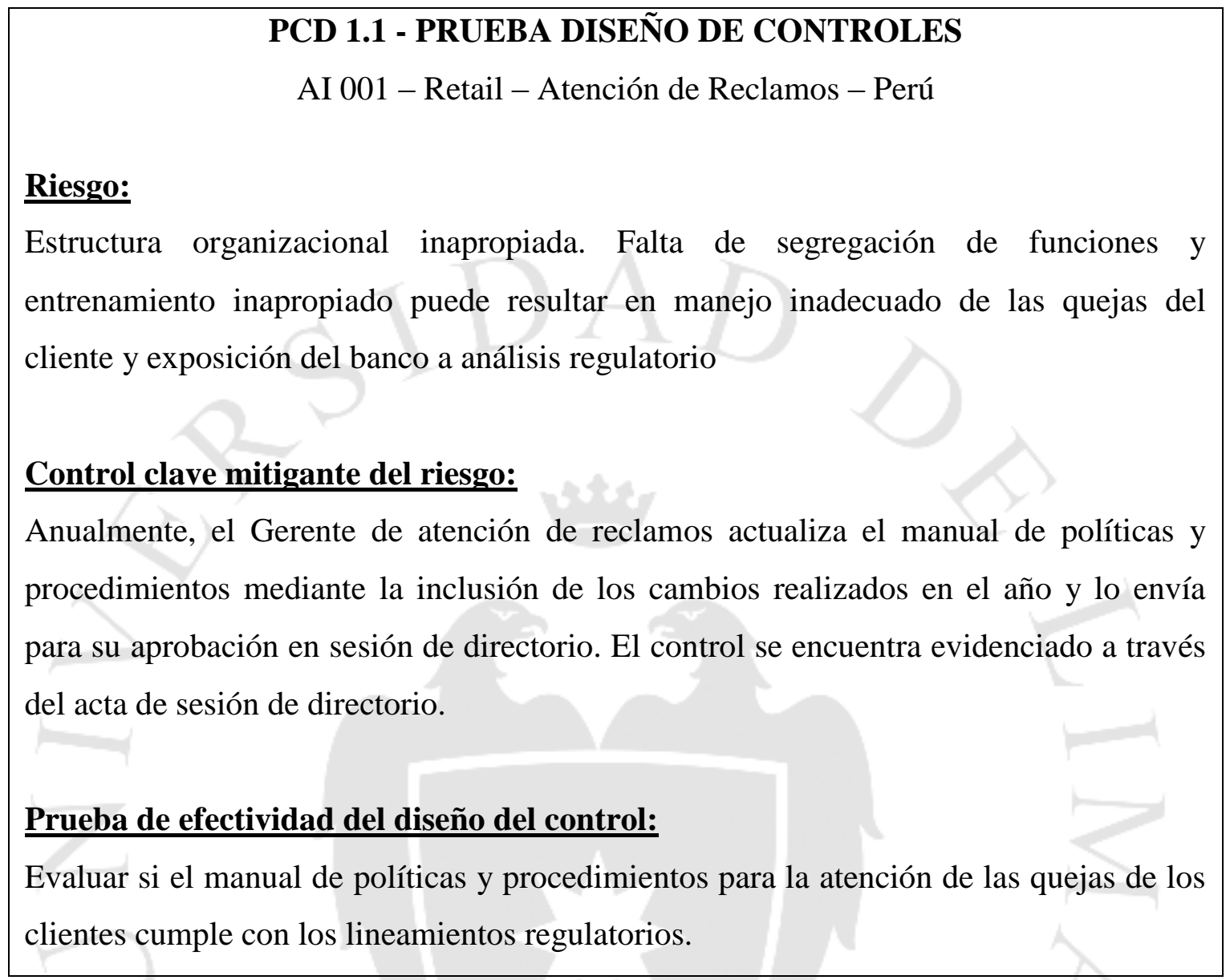

\begin{tabular}{|c|c|c|}
\hline$x_{-2}$ & 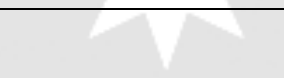 & $x_{x}$ \\
\hline Preguntas de diseño & Evidencia & Conclusión (S/N) \\
\hline $\begin{array}{l}\text { 1. ¿Es este el control adecuado } \\
\text { para mitigar el riesgo? }\end{array}$ & $\begin{array}{l}\text { - Manual de } \\
\text { atención al usuario }\end{array}$ & $\begin{array}{l}\text { Si } \\
\text { Debido a que se encuentra } \\
\text { formalizado y disponible para los } \\
\text { colaboradores. }\end{array}$ \\
\hline $\begin{array}{l}2 . \quad ¿ \text { El control es ejecutado por } \\
\text { la persona adecuada en el nivel } \\
\text { jerárquico apropiado? }\end{array}$ & & $\begin{array}{l}\text { Si } \\
\text { El gerente de atención al usuario es } \\
\text { responsable de la actualización y } \\
\text { difusión del manual. }\end{array}$ \\
\hline $\begin{array}{l}3 . \quad \text { ¿El control se ejecuta en la } \\
\text { etapa adecuada del proceso? }\end{array}$ & - & $\begin{array}{l}\text { Si } \\
\text { Debido a que se revisa previo a su } \\
\text { publicación. Se trata de un control } \\
\text { preventivo. }\end{array}$ \\
\hline ¿El control es sostenible? & & $\begin{array}{l}\text { Si } \\
\text { El control es sostenible debido a que } \\
\text { se encuentra formalizado en el } \\
\text { manual de atención al usuario el } \\
\text { cual ha sido debidamente difundido. } \\
\text { En tal sentido, a pesar de que el } \\
\text { personal rote en la compañía este }\end{array}$ \\
\hline
\end{tabular}




\begin{tabular}{|c|c|c|}
\hline & & $\begin{array}{l}\text { procedimiento se encuentra dentro } \\
\text { de las funciones del gerente de } \\
\text { atención al usuario por lo que el } \\
\text { control seguiría funcionando ante } \\
\text { eventos de rotación de personal. }\end{array}$ \\
\hline $\begin{array}{l}5 . \quad \text { ¿El control se encuentra } \\
\text { evidenciado? }\end{array}$ & $\begin{array}{l}\text { - Manual de } \\
\text { atención al usuario. } \\
-\quad \text { Actas de } \\
\text { directorio de aprobación } \\
\text { de manuales. }\end{array}$ & $\begin{array}{l}\text { Si } \\
\text { El manual de atención de reclamos } \\
\text { cuenta con control de cambios lo } \\
\text { cual permite validar su revisión y } \\
\text { posteriormente contrastarlo con las } \\
\text { actas de directorio. }\end{array}$ \\
\hline
\end{tabular}

\section{Conclusión:}

El control funciona adecuadamente a nivel diseño debido a que ha podido validarse la existencia del documento y que existen mecanismos internos para su revisión, aprobación y difusión.

\section{Evidencia adjunta:}

- $\quad$ Manual de atención al usuario (Incluye control de cambios)

- Acta de sesión de directorio de aprobación de manuales. 


\section{PCD 1.2 - PRUEBA DISEÑO DE CONTROLES}

$$
\text { AI } 001 \text { - Retail - Atención de Reclamos - Perú }
$$

\section{Riesgo:}

Estructura organizacional inapropiada. Falta de segregación de funciones y entrenamiento inapropiado puede resultar en manejo inadecuado de las quejas del cliente y exposición del banco a análisis regulatorio

\section{Control clave mitigante del riesgo:}

Anualmente, el Gerente de atención al cliente elabora el plan anual de capacitación en base a la cantidad de trabajadores y un cronograma de sesiones de entrenamiento. El control se encuentra evidenciado a través de dicho plan y su aprobación mediante sesión de directorio.

\section{Prueba de efectividad del diseño del control:}

Evaluar que el área responsable tiene un control vigente para asegurar que el personal ha sido apropiadamente entrenado en las estipulaciones regulatorias.

\begin{tabular}{|c|c|c|}
\hline Preguntas de diseño & Evidencia & Conclusión (S/N) \\
\hline $\begin{array}{l}1 . \quad \text { ¿Es este el control } \\
\text { adecuado para mitigar el riesgo? }\end{array}$ & $\begin{array}{l}\text { - Plan anual de } \\
\text { entrenamiento }\end{array}$ & $\begin{array}{l}\text { Si } \\
\text { Debido a que se encuentra formalizado y } \\
\text { disponible para los colaboradores. }\end{array}$ \\
\hline $\begin{array}{l}2 . \quad ¿ \text { El control es ejecutado } \\
\text { por la persona adecuada en el } \\
\text { nivel jerárquico apropiado? }\end{array}$ & & $\begin{array}{l}\text { Si } \\
\text { El gerente de atención al usuario es } \\
\text { responsable de la elaboración, difusión y } \\
\text { seguimiento de las actividades descritas en } \\
\text { el plan anual. }\end{array}$ \\
\hline $\begin{array}{l}3 . \quad ¿ E l \text { control se ejecuta } \\
\text { en la etapa adecuada del } \\
\text { proceso? }\end{array}$ & - & \begin{tabular}{l}
\multicolumn{4}{c}{$\mathbf{S i}$} \\
Debido a que se revisa previo a su \\
publicación. Se trata de un control \\
preventivo.
\end{tabular} \\
\hline $\begin{array}{l}\text { 4. ¿El control es } \\
\text { sostenible? }\end{array}$ & & $\begin{array}{l}\text { Si } \\
\text { El control es sostenible debido a que se } \\
\text { encuentra formalizado en el manual de } \\
\text { organización y funciones del gerente de } \\
\text { atención al usuario. }\end{array}$ \\
\hline
\end{tabular}




\begin{tabular}{|c|l|l|}
\hline & & $\begin{array}{l}\text { En tal sentido, a pesar de que el personal } \\
\text { rote en la compañía este procedimiento se } \\
\text { encuentra dentro de las funciones del } \\
\text { gerente de atención al usuario por lo que el } \\
\text { control seguiría funcionando ante eventos de } \\
\text { rotación de personal. }\end{array}$ \\
\hline \multirow{2}{*}{$\begin{array}{l}\text { ¿El control se encuentra } \\
\text { evidenciado? }\end{array}$} & $\begin{array}{l}\text { Plan anual de } \\
\text { entrenamiento } \\
\text { directorio de } \\
\text { aprobación del plan } \\
\text { anual. Actas de } \\
-\quad \text { Manual de } \\
\text { organización y } \\
\text { funciones. }\end{array}$ & $\begin{array}{l}\text { El plan anual de entrenamiento es aprobado } \\
\text { mediante actas de directorio. } \\
\text { Aunciones se encuentra descrita } \\
\text { responsabilidad del gerente. }\end{array}$ \\
\hline
\end{tabular}

\section{Conclusión:}

El control funciona adecuadamente a nivel diseño debido a que ha podido validarse la existencia del documento y que existen mecanismos internos para su revisión, aprobación y difusión.

\section{Evidencia adjunta:}

Plan anual de entrenamiento

Actas de directorio de aprobación del plan anual.

- $\quad$ Manual de organización y funciones. 


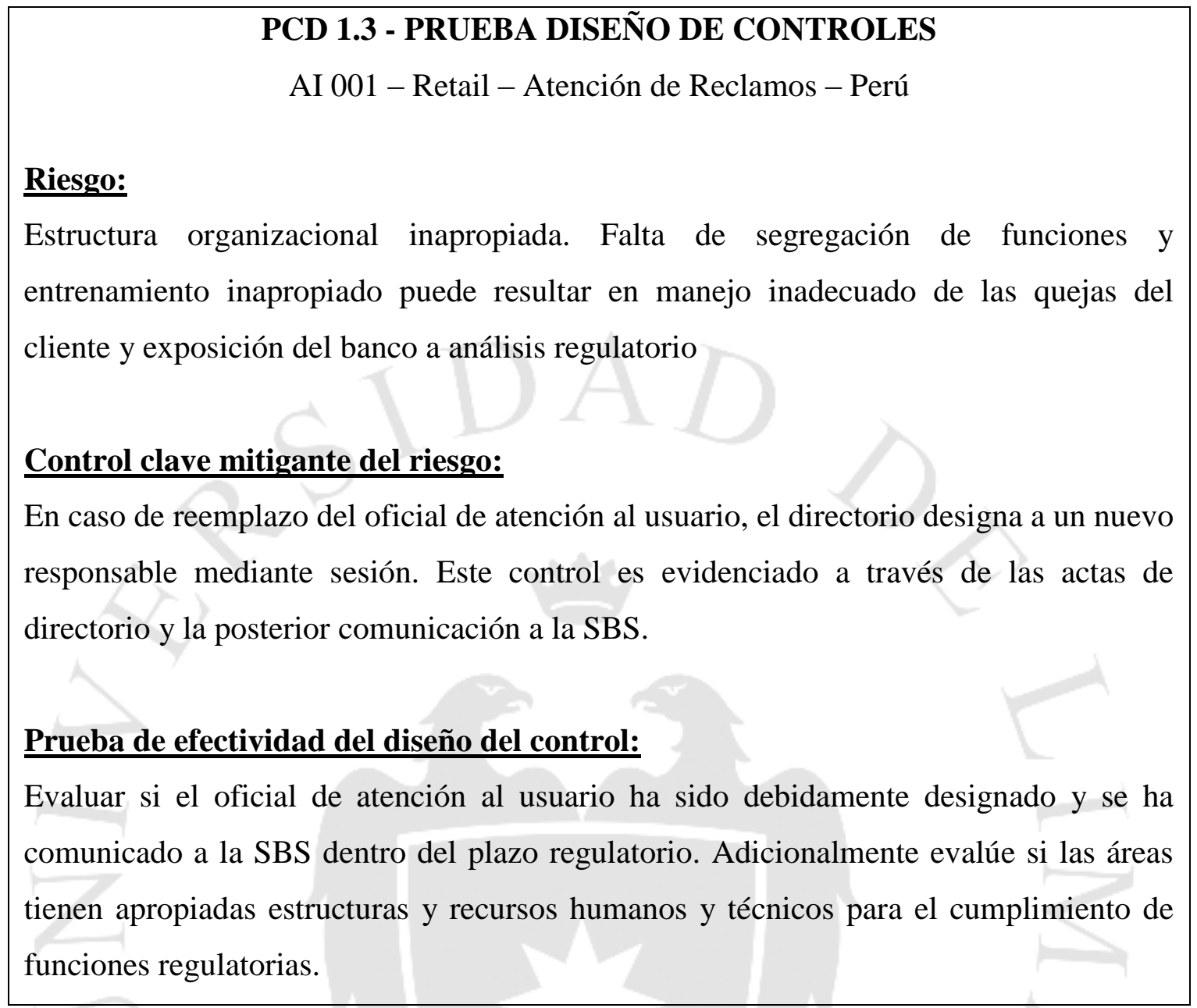

\begin{tabular}{|l|l|l|}
\hline \multicolumn{1}{|c|}{ Preguntas de diseño } & \multicolumn{1}{c|}{ Evidencia } & \multicolumn{1}{c|}{ Conclusión (S/N) } \\
\hline $\begin{array}{l}\text { 1. ¿Es este el control } \\
\text { adecuado para mitigar el } \\
\text { riesgo? }\end{array}$ & $\begin{array}{l}\text { Acta de directorio de } \\
\text { designación del oficial de } \\
\text { atención al usuario. }\end{array}$ & $\begin{array}{l}\text { Si } \\
\text { Debido a que se encuentra formalizado } \\
\text { y comunicado a la SBS. }\end{array}$ \\
\hline $\begin{array}{l}2 . \quad \text { ¿El control es } \\
\text { ejecutado por la persona } \\
\text { adecuada en el nivel } \\
\text { jerárquico apropiado? }\end{array}$ & $\begin{array}{l}\text { Si } \\
\text { El directorio es responsable de la } \\
\text { designación y el oficial de atención al } \\
\text { usuario de comunicarlo. }\end{array}$ \\
\hline $\begin{array}{l}\text { ¿El control se ejecuta } \\
\text { en la etapa adecuada del } \\
\text { proceso? }\end{array}$ & $\begin{array}{l}\text { Si } \\
\text { directorio previo a la comunicación. Se } \\
\text { trata de un control preventivo. }\end{array}$ \\
\hline $\begin{array}{l}\text { ¿El control es } \\
\text { sostenible? }\end{array}$ & $\begin{array}{l}\text { El control es sostenible debido a que se } \\
\text { encuentra formalizado a través de actas } \\
\text { de directorio y la comunicación formal } \\
\text { a la SBS. }\end{array}$ \\
\hline
\end{tabular}




\begin{tabular}{|c|c|l|}
\hline & & $\begin{array}{l}\text { personal rote en la compañía este } \\
\text { procedimiento se encuentra dentro de } \\
\text { las funciones del directorio. }\end{array}$ \\
\hline $\begin{array}{l}5 . \quad \text { ¿El control se } \\
\text { encuentra evidenciado? }\end{array}$ & $\begin{array}{l}-\quad \begin{array}{c}\text { Acta de directorio de } \\
\text { designación del oficial de } \\
\text { atención al usuario. } \\
\text { Carta de } \\
\text { comunicación a la SBS. }\end{array} \\
\text { A través del acta de sesión de } \\
\text { directorio y la carta de comunicación } \\
\text { de la designación del oficial de } \\
\text { atención al usuario a la SBS, }\end{array}$ \\
\hline
\end{tabular}

\section{Conclusión:}

El control funciona adecuadamente a nivel diseño debido a que ha podido validarse la existencia del documento y que existen mecanismos internos para su revisión, aprobación y difusión.

\section{Evidencia adjunta:}

- $\quad$ Acta de directorio de designación del oficial de atención al usuario.

- Carta de comunicación a la SBS. 


\section{PCD 2.1 - PRUEBA DISEÑO DE CONTROLES}

$$
\text { AI } 001 \text { - Retail - Atención de Reclamos - Perú }
$$

\section{Riesgo:}

Difusión inapropiada de la administración de quejas y procesos de presentación limitan el nivel de información disponible para los clientes y expone al banco a análisis regulatorios.

\section{Control clave mitigante del riesgo:}

Mensualmente, el supervisor de atención al usuario verifica la disponibilidad de folletería informativa del proceso de atención de reclamos en agencias y en la página web. Este control se encuentra evidenciado a través del checklist de revisión documentaria el cual es firmado por el gerente de tienda y el supervisor.

\section{Prueba de efectividad del diseño del control:}

Evaluar si existen controles internos que aseguren la adecuada divulgación de los procedimientos para reclamos y quejas en las sucursales y en la página WEB.

\begin{tabular}{|l|l|l|}
\hline \multicolumn{1}{|c|}{ Preguntas de diseño } & \multicolumn{1}{|c|}{ Evidencia } & \multicolumn{1}{|c|}{ Conclusión (S/N) } \\
\hline $\begin{array}{l}1 . \quad \text { ¿Es este el control } \\
\text { adecuado para mitigar el riesgo? }\end{array}$ & $\begin{array}{c}\text { Checklist de } \\
\text { revisión de folletería }\end{array}$ & $\begin{array}{l}\text { Debido a que se encuentra formalizado y } \\
\text { disponible para los ejecutores del } \\
\text { control, }\end{array}$ \\
\hline $\begin{array}{l}\text { ¿El control es } \\
\text { ejecutado por la persona } \\
\text { adecuada en el nivel jerárquico } \\
\text { apropiado? }\end{array}$ & $\begin{array}{l}\text { El supervisor de atención al usuario es } \\
\text { responsable de la validación de } \\
\text { folletería. }\end{array}$ \\
\hline $\begin{array}{l}\text { ¿El control se ejecuta } \\
\text { en la etapa adecuada del } \\
\text { proceso? }\end{array}$ & $\begin{array}{l}\text { Debido a que se revisa la disponibilidad } \\
\text { de folletería antes de que se acaben. Se } \\
\text { trata de un control preventivo. }\end{array}$ \\
\hline $\begin{array}{l}\text { ¿El control es } \\
\text { sostenible? }\end{array}$ & $\begin{array}{l}\text { El control es sostenible debido a que se } \\
\text { encuentra formalizado en el manual de } \\
\text { atención al usuario el cual ha sido } \\
\text { debidamente difundido. }\end{array}$ \\
\end{tabular}




\begin{tabular}{|l|l|l|}
\hline & & $\begin{array}{l}\text { rote en la compañía este procedimiento } \\
\text { se encuentra dentro de las funciones del } \\
\text { supervisor de atención al usuario por lo } \\
\text { que el control seguiría funcionando ante } \\
\text { eventos de rotación de personal. }\end{array}$ \\
\hline $\begin{array}{l}5 . \quad \text { ¿El control se } \\
\text { encuentra evidenciado? }\end{array}$ & $\begin{array}{l}\text { Manual de } \\
\text { atención al usuario. } \\
\text { Checklist de } \\
\text { revisión de folletería }\end{array}$ & $\begin{array}{l}\text { El checklist es elaborado por el } \\
\text { supervisor de atención al usuario } \\
\text { mensualmente. }\end{array}$ \\
\hline
\end{tabular}

\section{Conclusión:}

El control funciona adecuadamente a nivel diseño debido a que ha podido validarse la existencia del documento y que existen mecanismos internos para su revisión, aprobación y difusión.

\section{Evidencia adjunta:}

- $\quad$ Manual de atención al usuario.

- Checklist de revisión de folletería 


\section{PCD 4.1 - PRUEBA DISEÑO DE CONTROLES}

$$
\text { AI } 001 \text { - Retail - Atención de Reclamos - Perú }
$$

\section{Riesgo:}

Administración inapropiada y tardía de quejas de clientes expone al banco a análisis regulatorio.

\section{Control clave mitigante del riesgo:}

Diariamente, el analista backoffice de servicio al cliente monitorea los plazos de atención de reclamos mediante reportes diarios de rastreo de casos emitido por el sistema eclipse. Este control se encuentra evidenciado a través del cuadro de control de anticuamiento.

\section{Prueba de efectividad del diseño del control:}

Evaluar la existencia de un adecuado mecanismo de control que garantice una apropiada y oportuna administración de las quejas de clientes.

\begin{tabular}{|c|c|c|}
\hline Preguntas de diseño & Evidencia & Conclusión (S/N) \\
\hline $\begin{array}{l}\text { ¿Es este el control } \\
\text { adecuado para mitigar el } \\
\text { riesgo? }\end{array}$ & $\begin{array}{l}\text { - } \quad \text { Excel de revisión } \\
\text { de plazos de reclamos }\end{array}$ & $\begin{array}{l}\text { Si } \\
\text { Debido a que permite establecer prioridad } \\
\text { de atención de casos. }\end{array}$ \\
\hline $\begin{array}{l}2 . \quad \text { ¿El control es } \\
\text { ejecutado por la persona } \\
\text { adecuada en el nivel } \\
\text { jerárquico apropiado? }\end{array}$ & & $\begin{array}{l}\text { Si } \\
\text { El analista de backofice de atención al } \\
\text { usuario no participa del proceso de } \\
\text { evaluación de casos por lo que contaría } \\
\text { con independencia del proceso, es decir su } \\
\text { función es monitorear el cumplimiento de } \\
\text { los plazos de atención. }\end{array}$ \\
\hline $\begin{array}{l}3 . \quad \text { ¿El control se } \\
\text { ejecuta en la etapa adecuada } \\
\text { del proceso? }\end{array}$ & & $\begin{array}{l}\text { Si } \\
\text { Debido a que se revisa el cumplimiento de } \\
\text { plazos previo a su vencimiento. Se trata } \\
\text { de un control preventivo. }\end{array}$ \\
\hline $\begin{array}{l}\text { 4. ¿El control es } \\
\text { sostenible? }\end{array}$ & & $\begin{array}{l}\text { Si } \\
\text { El control es sostenible debido a que se } \\
\text { encuentra formalizado en el manual de } \\
\text { atención al usuario el cual ha sido } \\
\text { debidamente difundido. } \\
\text { En tal sentido, a pesar de que el personal }\end{array}$ \\
\hline
\end{tabular}




\begin{tabular}{|c|c|c|}
\hline & & $\begin{array}{l}\text { rote en la compañía este procedimiento se } \\
\text { encuentra dentro de las funciones del } \\
\text { analista de atención al usuario por lo que } \\
\text { el control seguiría funcionando ante } \\
\text { eventos de rotación de personal. }\end{array}$ \\
\hline $\begin{array}{l}5 . \quad ¿ \text { El control se } \\
\text { encuentra evidenciado? }\end{array}$ & $\begin{array}{l}\text { - } \quad \text { Manual de atención } \\
\text { al usuario. } \\
\text { - } \quad \text { Excel de revisión } \\
\text { de plazos de reclamos }\end{array}$ & $\begin{array}{l}\text { Si } \\
\text { A través del Excel de revisión de plazos } \\
\text { de reclamos }\end{array}$ \\
\hline
\end{tabular}

\section{Conclusión:}

El control funciona adecuadamente a nivel diseño debido a que ha podido validarse la existencia del documento y que existen mecanismos internos para su revisión, aprobación y difusión.

\section{Evidencia adjunta:}

Manual de atención al usuario.

- $\quad$ Excel de revisión de plazos de reclamos 


\section{PCD 5.1 - PRUEBA DISEÑO DE CONTROLES}

$$
\text { AI } 001 \text { - Retail - Atención de Reclamos - Perú }
$$

\section{Riesgo:}

Inapropiada administración de los archivos de quejas de los clientes expone al banco a análisis regulatorio.

\section{Control clave mitigante del riesgo:}

Diariamente, el analista de backoffice de servicio al cliente almacena los registros de reclamos en un sistema repositorio de imágenes del banco. El supervisor de servicios al consumidor ejecuta la validación semanal del sistema de imágenes mediante un muestreo en el cual verifica la integridad de los documentos. Este control se encuentra evidenciado a través de su matriz de revisión.

\section{Prueba de efectividad del diseño del control:}

Asegurar que existan archivos apropiados y la salvaguarda de registros. Evaluar que sean adecuados los controles internos y que existan para asegurar la segura custodia de los registros.

\begin{tabular}{|c|c|c|}
\hline Preguntas de diseño & Evidencia & Conclusión (S/N) \\
\hline $\begin{array}{l}1 . \quad ¿ \text { Es este el control } \\
\text { adecuado para mitigar el } \\
\text { riesgo? }\end{array}$ & $\begin{array}{l}\text { - } \quad \text { Matriz de } \\
\text { revisión de expedientes }\end{array}$ & $\begin{array}{l}\text { Si } \\
\text { Debido a que se verifica mediante muestreo } \\
\text { que todos los documentos se encuentren } \\
\text { tanto en físico como en digital. }\end{array}$ \\
\hline $\begin{array}{l}2 . \quad \text { ¿El control es } \\
\text { ejecutado por la persona } \\
\text { adecuada en el nivel } \\
\text { jerárquico apropiado? }\end{array}$ & & $\begin{array}{l}\text { Si } \\
\text { El supervisor de atención al usuario es } \\
\text { responsable de la revisión y escalamiento de } \\
\text { los casos. }\end{array}$ \\
\hline $\begin{array}{l}3 . \quad ¿ \text { El control se ejecuta } \\
\text { en la etapa adecuada del } \\
\text { proceso? }\end{array}$ & & $\begin{array}{l}\text { Si } \\
\text { Debido a que se revisa luego del } \\
\text { archivamiento. Se trata de un control } \\
\text { detectivo. }\end{array}$ \\
\hline $\begin{array}{l}\text { 4. ¿El control es } \\
\text { sostenible? }\end{array}$ & & $\begin{array}{l}\text { Si } \\
\text { El control es sostenible debido a que se } \\
\text { encuentra formalizado en el manual de } \\
\text { atención al usuario el cual ha sido } \\
\text { debidamente difundido. }\end{array}$ \\
\hline
\end{tabular}




\begin{tabular}{|l|l|l|}
\hline & & $\begin{array}{l}\text { En tal sentido, a pesar de que el personal } \\
\text { rote en la compañía este procedimiento se } \\
\text { encuentra dentro de las funciones del } \\
\text { supervisor de atención al usuario por lo que } \\
\text { el control seguiría funcionando ante eventos } \\
\text { de rotación de personal. }\end{array}$ \\
\hline $\begin{array}{l}5 . \quad \text { ¿El control se } \\
\text { encuentra evidenciado? }\end{array}$ & $\begin{array}{l}\text { Manual de } \\
\text { atención al usuario. } \\
-\begin{array}{c}\text { Matriz de } \\
\text { revisión de expedientes }\end{array}\end{array}$ & $\begin{array}{l}\text { A través del Matriz de revisión de } \\
\text { expedientes. }\end{array}$ \\
\hline
\end{tabular}

\section{Conclusión:}

El control funciona adecuadamente a nivel diseño debido a que ha podido validarse la existencia del documento y que existen mecanismos internos para su revisión, aprobación y difusión.

\section{Evidencia adjunta:}

- $\quad$ Manual de atención al usuario.

- $\quad$ Matriz de revisión de expedientes 


\section{PCD 6.1 - PRUEBA DISEÑO DE CONTROLES}

AI 001 - Retail - Atención de Reclamos - Perú

\section{Riesgo:}

Administración inapropiada y atrasada de los reportes de quejas trimestrales regulatorios expone al banco a análisis regulatorios.

\section{Control clave mitigante del riesgo:}

Trimestralmente, el supervisor de atención al usuario elabora reportes de gestión estadístico de los reclamos recibidos en el periodo y envía al área de contabilidad para que lo remitan a la SBS. Este control se encuentra evidenciado a través de los reportes trimestrales en comité de gerencia de atención de reclamos y el archivo de envío a la SBS.

\section{Prueba de efectividad del diseño del control:}

Asegurar que el área de quejas tiene un mecanismo para asegurar la apropiada administración de la generación, divulgación y entrega de reportes regulatorios.

\begin{tabular}{|c|c|c|}
\hline Preguntas de diseño & Evidencia & Conclusión (S/N) \\
\hline $\begin{array}{l}\text { 1. ¿Es este el control } \\
\text { adecuado para mitigar el } \\
\text { riesgo? }\end{array}$ & $\begin{array}{l}\text { - } \text { Métricas de } \\
\text { gestión trimestral } \\
\text { - } \quad \text { Reporte de } \\
\text { reclamos enviado a la SBS } \\
\text { - } \quad \text { Página Web }\end{array}$ & $\begin{array}{l}\text { Si } \\
\text { Debido a que se elaboran indicadores que } \\
\text { permiten analizar el comportamiento de los } \\
\text { reclamos y a su vez enviárselo al regulador. }\end{array}$ \\
\hline $\begin{array}{l}2 . \quad \text { ¿El control es } \\
\text { ejecutado por la persona } \\
\text { adecuada en el nivel } \\
\text { jerárquico apropiado? }\end{array}$ & & $\begin{array}{l}\text { Si } \\
\text { El supervisor de atención al usuario es } \\
\text { responsable de la elaboración y } \\
\text { presentación al comité de gerencia. }\end{array}$ \\
\hline $\begin{array}{l}3 . \quad \text { ¿El control se } \\
\text { ejecuta en la etapa adecuada } \\
\text { del proceso? }\end{array}$ & & $\begin{array}{l}\text { Si } \\
\text { Debido a que se presenta y revisa previo a } \\
\text { su presentación en comité de gerencia, } \\
\text { presentación en página web y envío a la } \\
\text { SBS. Se trata de un control preventivo. }\end{array}$ \\
\hline
\end{tabular}




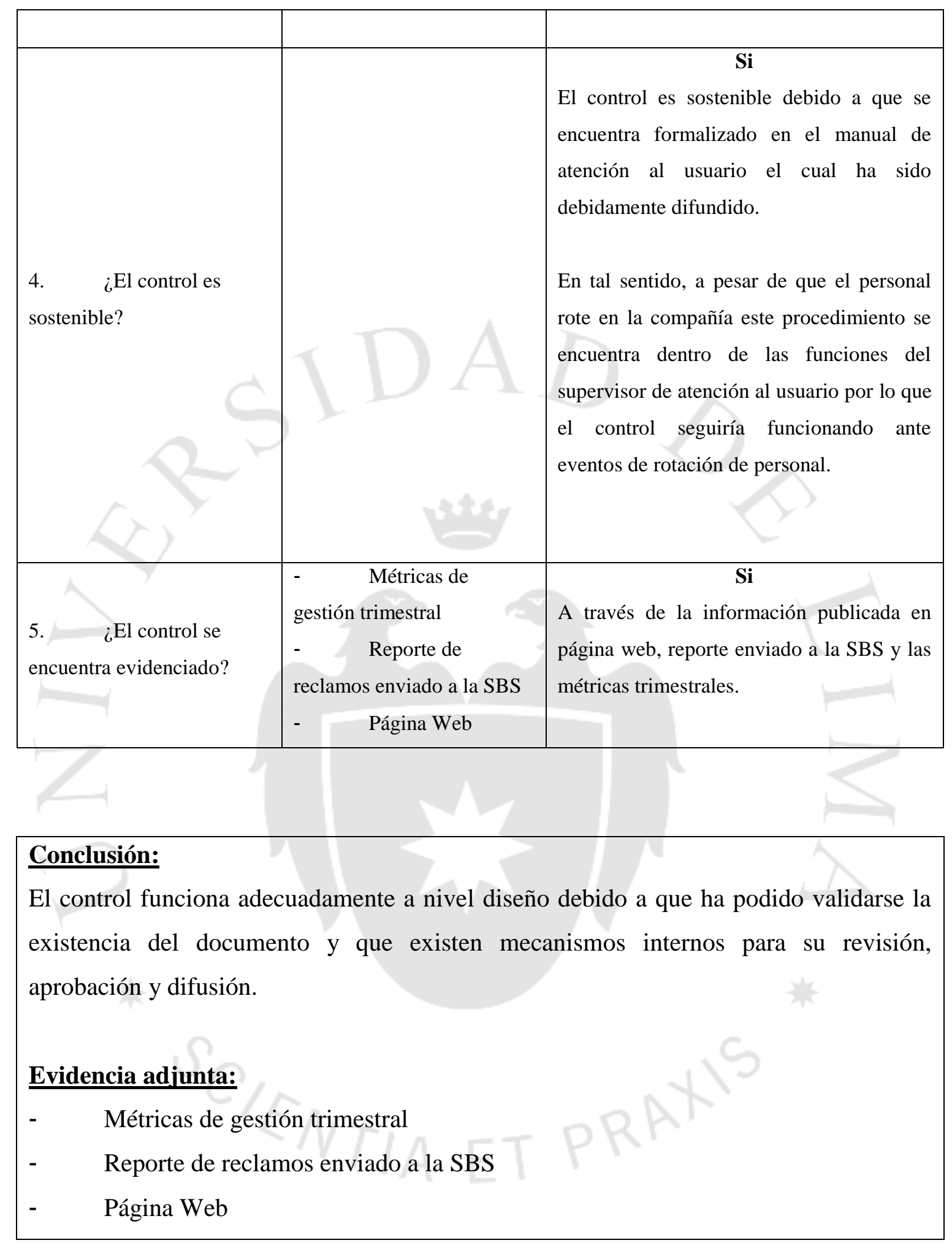




\section{ANEXO N ${ }^{\circ} 4$ - Formato de Muestreo}

\begin{tabular}{|l|l|}
\hline \multicolumn{2}{|c|}{$\begin{array}{c}\text { 2.1 Documento de Muestreo No estadístico } \\
\text { Para uso en las Pruebas de Efectividad Operativa (PEO) de Controles }\end{array}$} \\
\hline Auditoría: & AI 001/2014 Evaluación del proceso de atención de reclamos \\
\hline $\begin{array}{l}\text { Título del Control a } \\
\text { evaluar: }\end{array}$ & 2.1 Checklist mensual de información disponible para clientes \\
\hline
\end{tabular}

\begin{tabular}{|c|c|c|c|c|c|c|c|c|c|c|}
\hline \multicolumn{5}{|c|}{ 1. $\quad$ Riesgo de la Omisión: } & \multicolumn{6}{|c|}{ 2. $\quad$ Muestra seleccionada: } \\
\hline \multicolumn{2}{|c|}{ Diseño del Control } & & & & \multicolumn{2}{|c|}{ Control } & \multicolumn{4}{|c|}{$\begin{array}{l}\text { Tamaño mínimo } \\
\text { de la muestra }\end{array}$} \\
\hline $\begin{array}{l}\text { ¿Se considera el control } \\
\text { complejo? }\end{array}$ & $\mathrm{Si}$ & $\square$ & No & 区 & \multirow{6}{*}{$\begin{array}{l}\text { Naturaleza } \\
\text { de la } \\
\text { actividad de } \\
\text { control } \\
\text { Controles } \\
\text { Cíclicos } \\
\text { (Actividad de } \\
\text { Control } \\
\text { ocurre una } \\
\text { vez por ciclo) }\end{array}$} & Ocurrencia & \multicolumn{2}{|c|}{$\begin{array}{c}\text { Riesgo } \\
\text { Bajo }\end{array}$} & \multicolumn{2}{|c|}{$\begin{array}{c}\text { Riesgo } \\
\text { Alto }\end{array}$} \\
\hline \multirow{2}{*}{$\begin{array}{l}\text { ¿Se puede evitar el } \\
\text { control? }\end{array}$} & \multirow{2}{*}{$\mathrm{Si}$} & \multirow{2}{*}{$\square$} & \multirow{2}{*}{ No } & \multirow{2}{*}{ 凶 } & & Anual & 1 & $\square$ & 1 & $\square$ \\
\hline & & & & & & Trimestral & 1 & $\square$ & 2 & $\square$ \\
\hline \multirow{2}{*}{$\begin{array}{l}\text { ¿Puede la gerencia } \\
\text { anular el control? }\end{array}$} & \multirow{2}{*}{$\mathrm{Si}$} & \multirow{2}{*}{$\square$} & \multirow{2}{*}{ No } & \multirow{2}{*}{ 区 } & & Mensual & 2 & $\square$ & 4 & 区 \\
\hline & & & & & & Semanal & 5 & $\square$ & 8 & $\square$ \\
\hline $\begin{array}{l}\text { ¿Se requiere de juicio o } \\
\text { criterio para operar el } \\
(\text { los }) \text { control(es) }\end{array}$ & $\mathrm{Si}$ & $\square$ & No & 区 & & \multirow{2}{*}{$\begin{array}{l}\text { Múltiple } \\
\text { por día }\end{array}$} & \multirow[t]{2}{*}{25} & \multirow{2}{*}{$\square$} & \multirow[t]{2}{*}{40} & \multirow[t]{2}{*}{$\square$} \\
\hline $\begin{array}{l}\text { ¿Es el control } \\
\text { manualmente ejecutado? }\end{array}$ & $\mathrm{Si}$ & $\square$ & No & 区 & & & & & & \\
\hline \multicolumn{5}{|c|}{ b) ¿Experiencia Pasada del Control? } & \multirow{5}{*}{$\begin{array}{l}\text { Controles } \\
\text { para los } \\
\text { casos } \\
\text { específicos } \\
\text { (Actividades } \\
\text { aproximadas } \\
\text { de control } \\
\text { por período } \\
\text { de auditoría) }\end{array}$} & $1-5$ & 1 & $\square$ & 2 & $\square$ \\
\hline \multirow[b]{2}{*}{$\begin{array}{l}\text { Fueron algunos asuntos } \\
\text { asociados con este } \\
\text { (estos) control(es) } \\
\text { identificados por } \\
\text { Auditoría Interna, } \\
\text { Organismos reguladores } \\
\text { o KPMG? }\end{array}$} & \multirow[b]{2}{*}{$\mathrm{Si}$} & \multirow[b]{2}{*}{$\square$} & \multirow[b]{2}{*}{ No } & \multirow[b]{2}{*}{ 口 } & & $6-50$ & 2 & $\square$ & 4 & $\square$ \\
\hline & & & & & & $51-200$ & 5 & $\square$ & 8 & $\square$ \\
\hline \multirow{4}{*}{\multicolumn{5}{|c|}{$\begin{array}{l}\text { Otra información importante relacionada al riesgo } \\
\text { u omisión: }\end{array}$}} & & $201-500$ & 10 & $\square$ & 25 & $\square$ \\
\hline & & & & & & $>500$ & 25 & $\square$ & 40 & $\square$ \\
\hline & & & & & $\begin{array}{l}\text { Controles } \\
\text { automatizados }\end{array}$ & & \multicolumn{4}{|l|}{1} \\
\hline & & & & & \multicolumn{6}{|c|}{$\begin{array}{l}\text { ** Esta frecuencia se aplica a controles de medio } \\
\text { año }\end{array}$} \\
\hline $\begin{array}{l}\text { c) ¿Conclusión: } \\
\text { Ha sido evaluado el } \\
\text { riesgo como Alto o } \\
\text { Bajo? }\end{array}$ & Alto & 凶 & Bajo & $\square$ & & & & & & \\
\hline
\end{tabular}

\section{Detalles del Control}




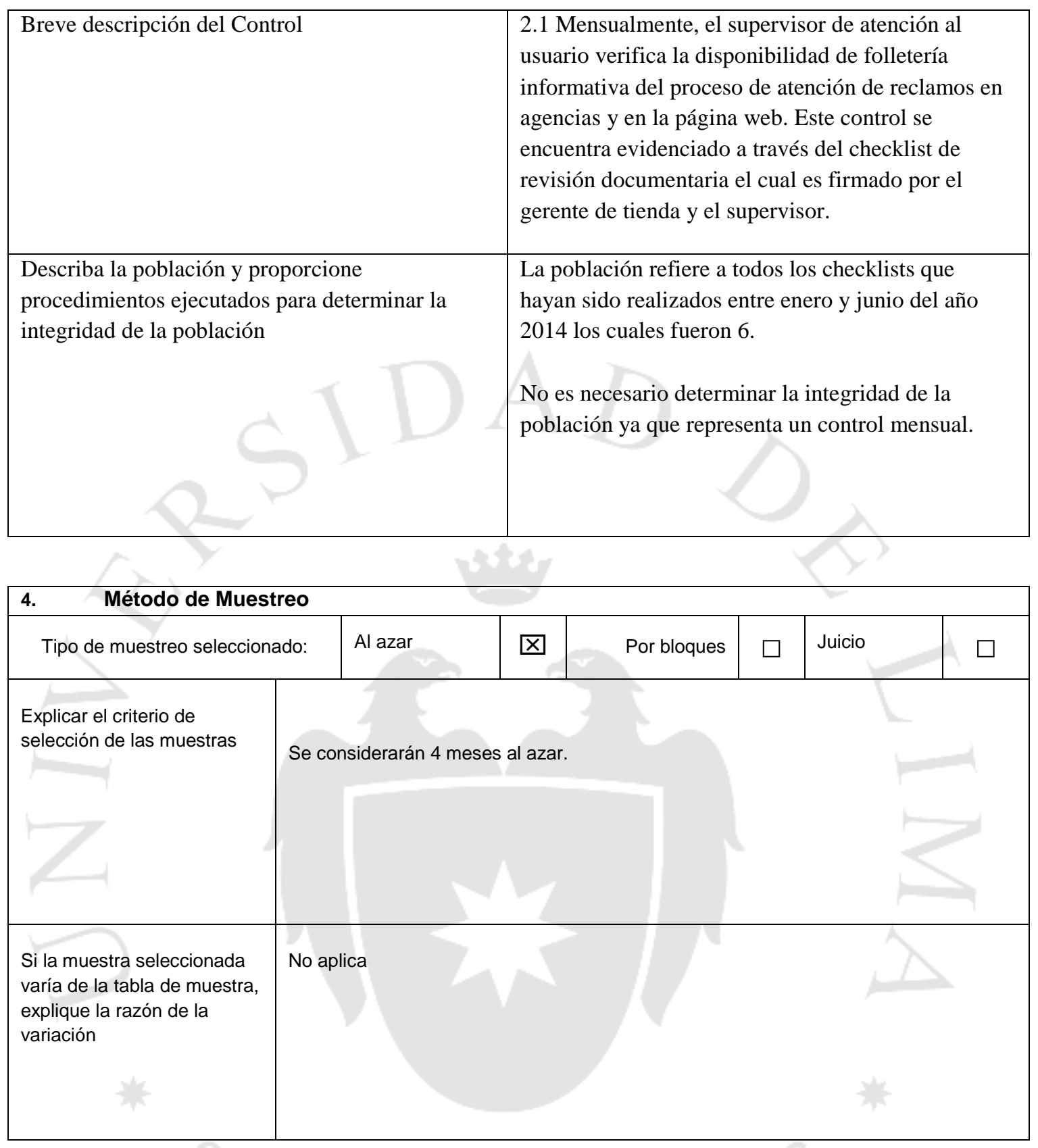




\begin{tabular}{|c|c|}
\hline \multicolumn{2}{|c|}{$\begin{array}{c}\text { 3.1 Documento de Muestreo No estadístico } \\
\text { Para uso en las Pruebas de Efectividad Operativa (PEO) de Controles }\end{array}$} \\
\hline Auditoría: & AI 001/2014 Evaluación del proceso de atención de reclamos \\
\hline $\begin{array}{l}\text { Título del Control a } \\
\text { evaluar: }\end{array}$ & $\begin{array}{l}\text { 3.1 Controles de registro, monitoreo del plazo de respuesta y archivamiento } \\
\text { de los reclamos. }\end{array}$ \\
\hline
\end{tabular}

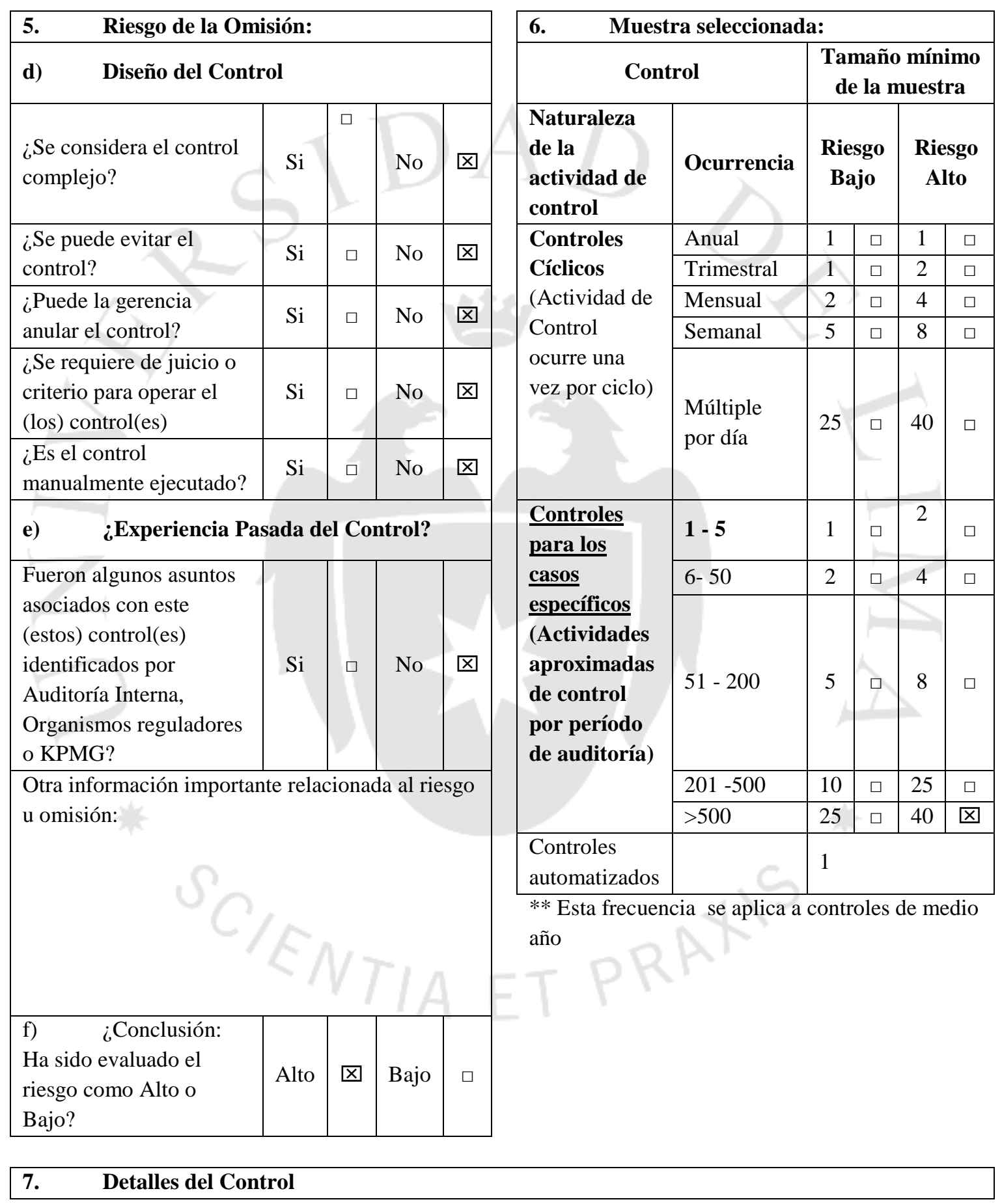




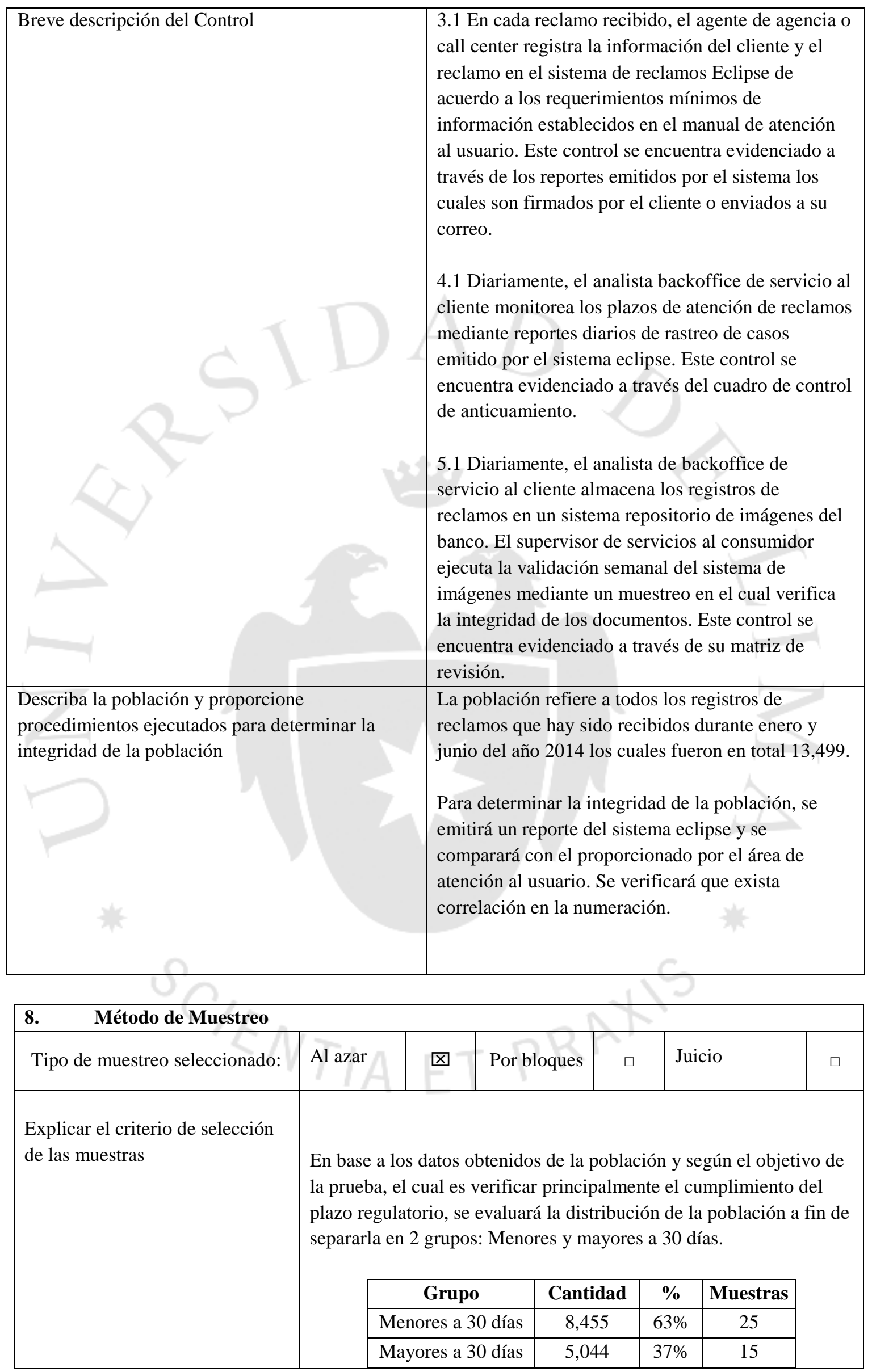




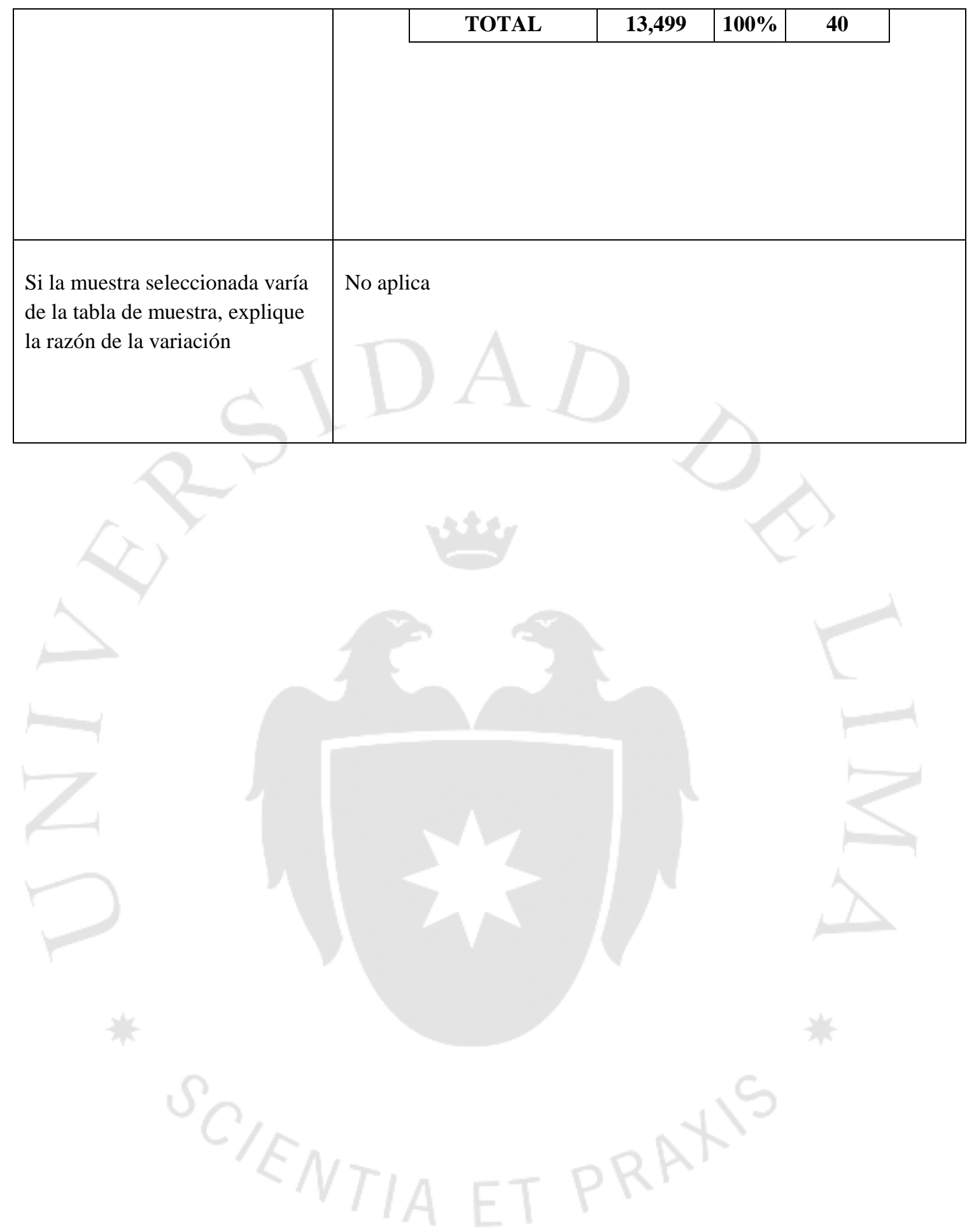




\begin{tabular}{|l|l|}
\hline \multicolumn{2}{|c|}{$\begin{array}{c}\text { 6.1 Documento de Muestreo No estadístico } \\
\text { Para uso en las Pruebas de Efectividad Operativa (PEO) de Controles }\end{array}$} \\
\hline Auditoría: & Al 001/2014 Evaluación del proceso de atención de reclamos \\
\hline $\begin{array}{l}\text { Título del Control a } \\
\text { evaluar: }\end{array}$ & 6.1 Reportes a la gerencia y el regulador \\
\hline
\end{tabular}

\begin{tabular}{|c|c|c|c|c|}
\hline \multicolumn{5}{|c|}{ Riesgo de la Omisión: } \\
\hline \multicolumn{5}{|c|}{ Diseño del Control } \\
\hline $\begin{array}{l}\text { ¿Se considera el control } \\
\text { complejo? }\end{array}$ & $\mathrm{Si}$ & $\square$ & No & 凶 \\
\hline $\begin{array}{l}\text { ¿Se puede evitar el } \\
\text { control? }\end{array}$ & $\mathrm{Si}$ & $\square$ & No & 凶 \\
\hline $\begin{array}{l}\text { ¿Puede la gerencia anular } \\
\text { el control? }\end{array}$ & $\mathrm{Si}$ & $\square$ & No & 凶 \\
\hline $\begin{array}{l}\text { ¿Se requiere de juicio o } \\
\text { criterio para operar el (los) } \\
\text { control(es) }\end{array}$ & $\mathrm{Si}$ & $\square$ & No & 凶 \\
\hline $\begin{array}{l}\text { ¿Es el control } \\
\text { manualmente ejecutado? }\end{array}$ & $\mathrm{Si}$ & $\square$ & No & 凶 \\
\hline
\end{tabular}

h) ¿Experiencia Pasada del Control?

Fueron algunos asuntos asociados con este (estos) control(es) identificados por Auditoría Interna, Organismos reguladores o KPMG?

Otra información importante relacionada al riesgo $u$ omisión:

i) ¿Conclusión: Ha sido evaluado el riesgo como Alto o Bajo?
10. Muestra seleccionada:

\begin{tabular}{|c|c|c|c|c|c|}
\hline \multicolumn{2}{|c|}{ Control } & \multicolumn{4}{|c|}{$\begin{array}{l}\text { Tamaño mínimo de } \\
\text { la muestra }\end{array}$} \\
\hline \multirow{4}{*}{$\begin{array}{l}\text { Naturaleza de } \\
\text { la actividad } \\
\text { de control } \\
\text { Controles } \\
\text { Cíclicos } \\
\text { (Actividad de } \\
\text { Control ocurre } \\
\text { una vez por } \\
\text { ciclo) }\end{array}$} & \multirow{2}{*}{$\begin{array}{l}\text { Ocurrencia } \\
\text { Anual }\end{array}$} & \multicolumn{2}{|c|}{$\begin{array}{c}\text { Riesgo } \\
\text { Bajo }\end{array}$} & \multicolumn{2}{|c|}{$\begin{array}{l}\text { Riesgo } \\
\text { Alto }\end{array}$} \\
\hline & & 1 & $\square$ & 1 & $\square$ \\
\hline & Trimestral & 1 & $\square$ & 2 & $\mathrm{X}$ \\
\hline & Mensual & 2 & $\square$ & 4 & $\square$ \\
\hline & Semanal & 5 & $\square$ & 8 & $\square$ \\
\hline & $\begin{array}{l}\text { Múltiple por } \\
\text { día }\end{array}$ & 25 & $\square$ & 40 & $\square$ \\
\hline \multirow{5}{*}{$\begin{array}{l}\text { Controles } \\
\text { para los } \\
\text { casos } \\
\text { específicos } \\
\text { (Actividades } \\
\text { aproximadas } \\
\text { de control } \\
\text { por período } \\
\text { de auditoría) }\end{array}$} & $1-5$ & 1 & $\square$ & 2 & $\square$ \\
\hline & 6- 50 & 2 & $\square$ & 4 & $\square$ \\
\hline & $51-200$ & 5 & $\square$ & 8 & $\square$ \\
\hline & $201-500$ & 10 & $\square$ & 25 & $\square$ \\
\hline & $>500$ & 25 & $\square$ & 40 & $\square$ \\
\hline $\begin{array}{l}\text { Controles } \\
\text { automatizados }\end{array}$ & & \multicolumn{4}{|l|}{1} \\
\hline
\end{tabular}

${ }^{\star *}$ Esta frecuencia se aplica a controles de medio año

\begin{tabular}{|l|l|}
\hline 11. Detalles del Control & $\begin{array}{l}6.1 \text { Trimestralmente, el supervisor de } \\
\text { atención al usuario elabora reportes } \\
\text { de gestión estadístico de los reclamos } \\
\text { recibidos en el periodo y envía al área } \\
\text { de contabilidad para que lo remitan a } \\
\text { la SBS. Este control se encuentra } \\
\text { evidenciado a través de los reportes } \\
\text { trimestrales en comité de gerencia de } \\
\text { atención de reclamos y el archivo de } \\
\text { envío a la SBS. }\end{array}$ \\
\hline
\end{tabular}




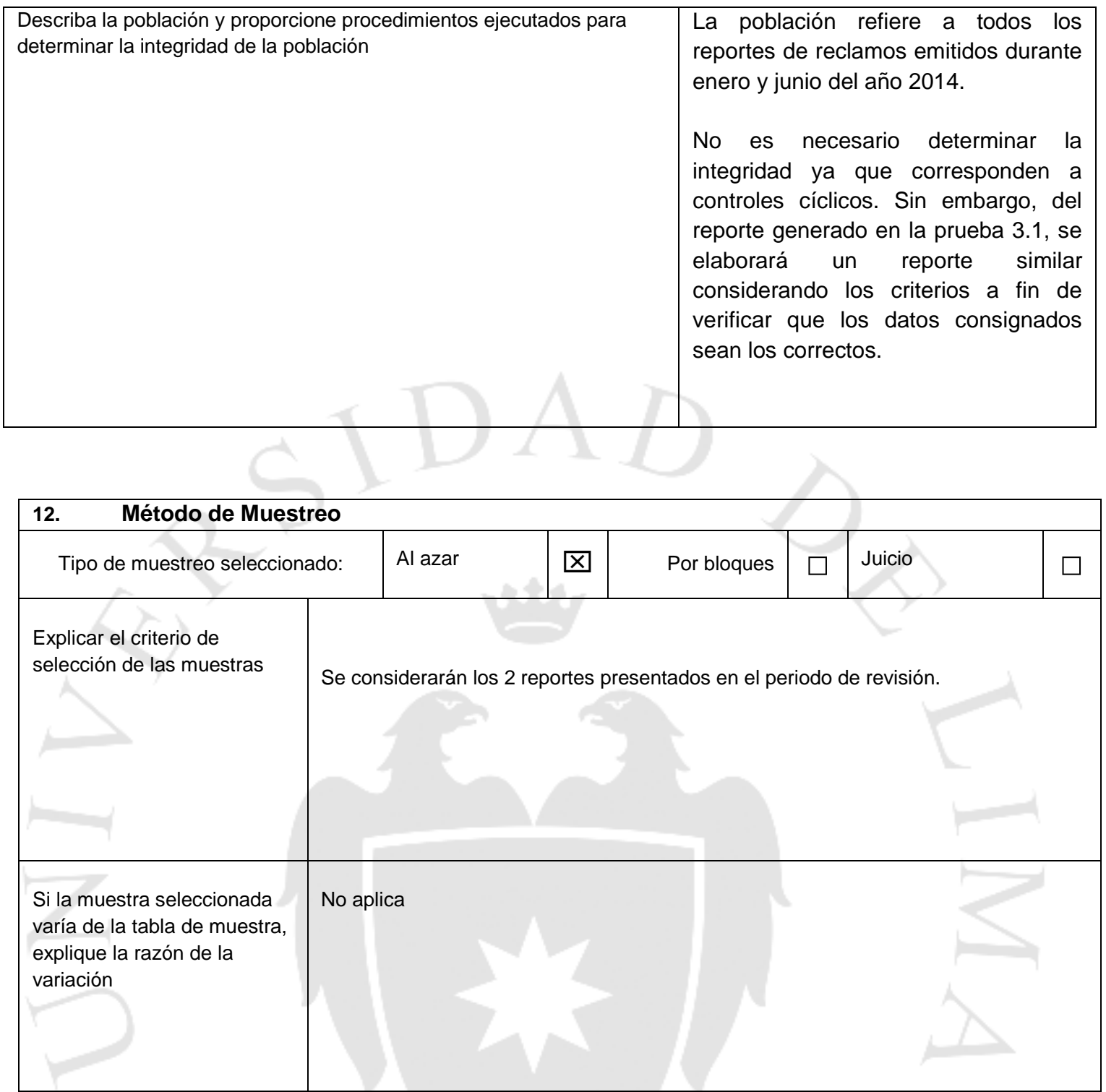




\section{ANEXO N ${ }^{\circ} 5$ - Tabla de niveles de observaciones}

\begin{tabular}{|c|c|c|c|c|}
\hline \multicolumn{5}{|c|}{ NIVELES DE CLASIFICACIÓN DE OBSERVACIONES } \\
\hline Nivel & Nivel General & Riesgo Regulatorio & $\begin{array}{c}\text { Desviación de } \\
\text { políticas }\end{array}$ & $\begin{array}{c}\text { Riesgo } \\
\text { Reputacional } \\
\end{array}$ \\
\hline $\begin{array}{r}\text { Niv } \\
1\end{array}$ & $\begin{array}{lrr}\begin{array}{lr}\text { Debilidad } \\
\text { control a }\end{array} & \text { en } \\
\text { global } & \text { nivel } \\
\text { impactar } & \text { puede } \\
\text { estrategias } & \text { las } \\
\text { objetivos } & \text { u } \\
\text { Banco. } & \text { del } \\
\text { inmediata } & \text { Acción } \\
\text { Gerencia } & & \text { la } \\
\text { requerida } & & \text { para } \\
\text { asegurar } & \text { que } & \text { los } \\
\text { riesgos } & & \text { son } \\
\text { mitigados } & \text { y } & \text { la } \\
\text { remediación } & \text { es } \\
\text { efectiva. } & & \end{array}$ & $\begin{array}{l}\text { Debilidad en el control } \\
\text { que puede resultar en } \\
\text { acciones del regulador } \\
\text { que generarían un } \\
\text { efecto adverso en la } \\
\text { capacidad del Banco de } \\
\text { continuar con sus } \\
\text { operaciones en un país } \\
\text { o región y el riesgo de } \\
\text { sanción o multa. } \\
\text { La debilidad en el } \\
\text { control puede deberse a } \\
\text { incumplimientos } \\
\text { sustanciales } \\
\text { reiterativos de la } \\
\text { regulación. }\end{array}$ & $\begin{array}{l}\text { Debilidad en el } \\
\text { control que se } \\
\text { desarrolla debido } \\
\text { al } \\
\text { incumplimiento } \\
\text { de políticas } \\
\text { corporativas. La } \\
\text { política puede no } \\
\text { existir, estar } \\
\text { inapropiadamente } \\
\text { diseñada o no } \\
\text { operar } \\
\text { eficazmente. }\end{array}$ & $\begin{array}{l}\text { Riesgo } \\
\text { reputacional } \\
\text { debido a una } \\
\text { actividad que } \\
\text { puede resultar en } \\
\text { publicidad } \\
\text { negativa del } \\
\text { banco. } \\
\text { debilidad en el } \\
\text { control puede } \\
\text { existir en una } \\
\text { sucursal, } \\
\text { agencia, país, } \\
\text { múltiples } \\
\text { sucursales, una } \\
\text { región } \\
\text { globalmente lo } \\
\text { cual puede } \\
\text { generar } \\
\text { impacto negativo } \\
\text { en la reputación } \\
\text { del banco. }\end{array}$ \\
\hline $\begin{array}{c}\text { Nivel } \\
2\end{array}$ & 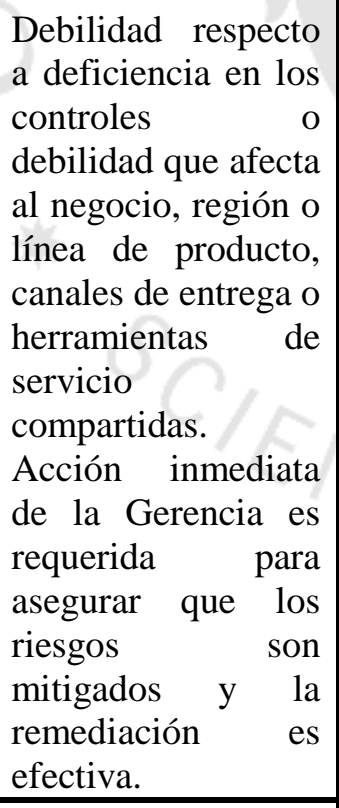 & $\begin{array}{l}\text { Debilidad en el control } \\
\text { que puede resultar en } \\
\text { acciones del regulador } \\
\text { que generarían un } \\
\text { efecto adverso en la } \\
\text { capacidad del Banco de } \\
\text { continuar con sus } \\
\text { operaciones en un país } \\
\text { o región y el riesgo de } \\
\text { sanción o multa. }\end{array}$ & $\begin{array}{l}\text { Regional: Falta } \\
\text { de políticas, } \\
\text { inapropiado } \\
\text { diseño de las } \\
\text { políticas o falla } \\
\text { en la eficacia } \\
\text { operativa de las } \\
\text { mismas que } \\
\text { generaría fallas } \\
\text { en los controles. }\end{array}$ & $\begin{array}{l}\text { Riesgo } \\
\text { reputacional } \\
\text { debido a una } \\
\text { actividad que } \\
\text { puede resultar en } \\
\text { publicidad } \\
\text { negativa del } \\
\text { banco. } \text { La } \\
\text { debilidad en el } \\
\text { control puede } \\
\text { existir a nivel } \\
\text { regional lo cual } \\
\text { puede generar un } \\
\text { impacto negativo } \\
\text { en la reputación } \\
\text { del banco. }\end{array}$ \\
\hline $\begin{array}{c}\text { Nivel } \\
3\end{array}$ & $\begin{array}{lr}\text { Debilidad } & \text { del } \\
\text { control a } & \text { nivel } \\
\text { funcional } & \mathrm{o} \\
\text { producto } & \mathrm{e}\end{array}$ & $\begin{array}{l}\text { Debilidad en el control } \\
\text { que puede resultar en } \\
\text { acciones del regulador } \\
\text { que impactarían en el }\end{array}$ & $\begin{array}{l}\text { Políticas y } \\
\text { procedimientos } \\
\text { funcionales o } \\
\text { legales, falta de }\end{array}$ & $\begin{array}{ll}\text { Riesgo } & \\
\text { reputacional } \\
\text { debido a una } \\
\text { actividad que }\end{array}$ \\
\hline
\end{tabular}




\begin{tabular}{|c|c|c|c|c|}
\hline & $\begin{array}{l}\text { inconformidad con } \\
\text { las políticas del } \\
\text { banco. Actividades } \\
\text { de gobierno fallidas } \\
\text { o múltiples } \\
\text { desviaciones en los } \\
\text { procedimientos } \\
\text { establecidos. }\end{array}$ & $\begin{array}{l}\text { negocio de una región o } \\
\text { red de agencias. }\end{array}$ & $\begin{array}{l}\text { políticas, } \\
\text { inapropiado } \\
\text { diseño de las } \\
\text { políticas, o fallas } \\
\text { en la eficacia } \\
\text { operativa de una } \\
\text { política puede } \\
\text { generar fallas en } \\
\text { los controles. }\end{array}$ & $\begin{array}{l}\text { puede resultar en } \\
\text { publicidad } \\
\text { negativa del } \\
\text { banco. } \\
\text { debilidad en el } \\
\text { control puede } \\
\text { existir a nivel } \\
\text { país lo cual } \\
\text { puede generar un } \\
\text { impacto negativo } \\
\text { en la reputación } \\
\text { del banco. } \\
\end{array}$ \\
\hline Niv & $\begin{array}{l}\text { Debilidad } \\
\text { control respecto a } \\
\text { desviación del } \\
\text { marco regulatorio } \\
\text { requiere acción } \\
\text { inmediata de la } \\
\text { gerencia y planes } \\
\text { de } \\
\text { correctivos acción } \\
\text { alinearse a para } \\
\text { normativa vigente. }\end{array}$ & $\begin{array}{l}\text { Debilidad en el control } \\
\text { que puede resultar en } \\
\text { acciones de regulador } \\
\text { que afectarían a la } \\
\text { entidad o jurisdicción } \\
\text { local y puede } \\
\text { relacionarse a violación } \\
\text { de políticas o } \\
\text { procedimientos. }\end{array}$ & $\begin{array}{l}\text { Políticas y } \\
\text { procedimientos } \\
\text { del negocio o de } \\
\text { productos, } \\
\text { inapropiado } \\
\text { diseño de las } \\
\text { políticas, o fallas } \\
\text { en la eficacia } \\
\text { operativa de una } \\
\text { política puede } \\
\text { generar fallas en } \\
\text { los controles. }\end{array}$ & $\begin{array}{l}\text { Riesgo } \\
\text { reputacional } \\
\text { debido a una } \\
\text { actividad que } \\
\text { puede resultar en } \\
\text { publicidad } \\
\text { negativa del } \\
\text { banco. } \\
\text { debilidad en el } \\
\text { control puede } \\
\text { existir a entidad } \\
\text { lo cual puede } \\
\text { generar un } \\
\text { impacto negativo } \\
\text { en la reputación } \\
\text { del banco. }\end{array}$ \\
\hline $\begin{array}{c}\text { Nivel } \\
5\end{array}$ & $\begin{array}{l}\text { Debilidad del } \\
\text { control requiere de } \\
\text { atención por parte } \\
\text { de la Gerencia y } \\
\text { medidas correctivas } \\
\text { a nivel proceso o } \\
\text { agencias. }\end{array}$ & $\begin{array}{lr}\text { Debilidad en el control } \\
\text { que puede resultar en } \\
\text { sanciones } \\
\text { comentarios } & \text { del } \\
\text { regulador a } & \text { nivel } \\
\text { sucursales. } & \end{array}$ & $\begin{array}{l}\text { Políticas y } \\
\text { procedimientos } \\
\text { de agencias, } \\
\text { inapropiado } \\
\text { diseño de las } \\
\text { políticas, o fallas } \\
\text { en la eficacia } \\
\text { operativa de una } \\
\text { política puede } \\
\text { generar fallas en } \\
\text { los controles. }\end{array}$ & $\begin{array}{l}\text { Riesgo } \\
\text { reputacional } \\
\text { debido a una } \\
\text { actividad que } \\
\text { puede resultar en } \\
\text { publicidad } \\
\text { negativa del } \\
\text { banco. } \\
\text { debilidad en el } \\
\text { control puede } \\
\text { existir a agencia } \\
\text { lo cual puede } \\
\text { generar un } \\
\text { impacto negativo } \\
\text { en la reputación } \\
\text { del banco. }\end{array}$ \\
\hline
\end{tabular}


ESCALA DE CALIFICACION DEL PROCESO

Calificación del proceso

\begin{tabular}{|c|c|c|c|}
\hline $\begin{array}{c}\text { Suficiente } \\
\text { Aseguramiento }\end{array}$ & $\begin{array}{c}\text { Oportunidad de } \\
\text { Mejora }\end{array}$ & $\begin{array}{l}\text { Aseguramiento } \\
\text { Limitado }\end{array}$ & $\begin{array}{c}\text { Insuficiente } \\
\text { Aseguramiento }\end{array}$ \\
\hline $\begin{array}{l}\text { Los resultados de la } \\
\text { auditoría indican que } \\
\text { existe suficiente } \\
\text { aseguramiento en el } \\
\text { diseño y efectividad } \\
\text { operativa de los } \\
\text { controles para mitigar o } \\
\text { administrar los riesgos a } \\
\text { los cuales el proceso } \\
\text { auditado se encuentra } \\
\text { expuesto. }\end{array}$ & $\begin{array}{l}\text { Los resultados de la } \\
\text { auditoría indican que a } \\
\text { pesar que se cuenta con } \\
\text { suficiente } \\
\text { aseguramiento en el } \\
\text { diseño y efectividad } \\
\text { operativa de los } \\
\text { controles para mitigar o } \\
\text { administrar los riesgos } \\
\text { a los cuales el proceso } \\
\text { auditado se encuentra } \\
\text { expuesto, debe } \\
\text { prestarse atención en } \\
\text { adecuar cierto } \\
\text { control(es) de cierta(s) } \\
\text { área(s). }\end{array}$ & $\begin{array}{l}\text { Los resultados de la } \\
\text { auditoría indican existe } \\
\text { un nivel de } \\
\text { aseguramiento limitado } \\
\text { en el diseño y } \\
\text { efectividad operativa de } \\
\text { los controles para } \\
\text { mitigar o administrar } \\
\text { los riesgos a los cuales } \\
\text { el proceso auditado se } \\
\text { encuentra expuesto. La } \\
\text { existencia de } \\
\text { observaciones } \\
\text { reiterativas también se } \\
\text { considera en esta } \\
\text { calificación. }\end{array}$ & $\begin{array}{l}\text { Los resultados de la } \\
\text { auditoría indican existe } \\
\text { un nivel de } \\
\text { aseguramiento } \\
\text { insuficiente en el } \\
\text { diseño y efectividad } \\
\text { operativa de los } \\
\text { controles para mitigar o } \\
\text { administrar los riesgos } \\
\text { a los cuales el proceso } \\
\text { auditado se encuentra } \\
\text { expuesto. }\end{array}$ \\
\hline
\end{tabular}

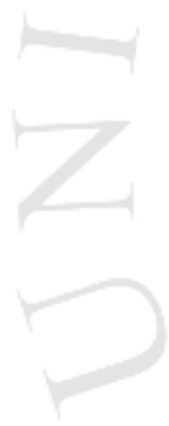




\section{ANEXO N ${ }^{\circ} 6$ - Reporte de auditoría interna}

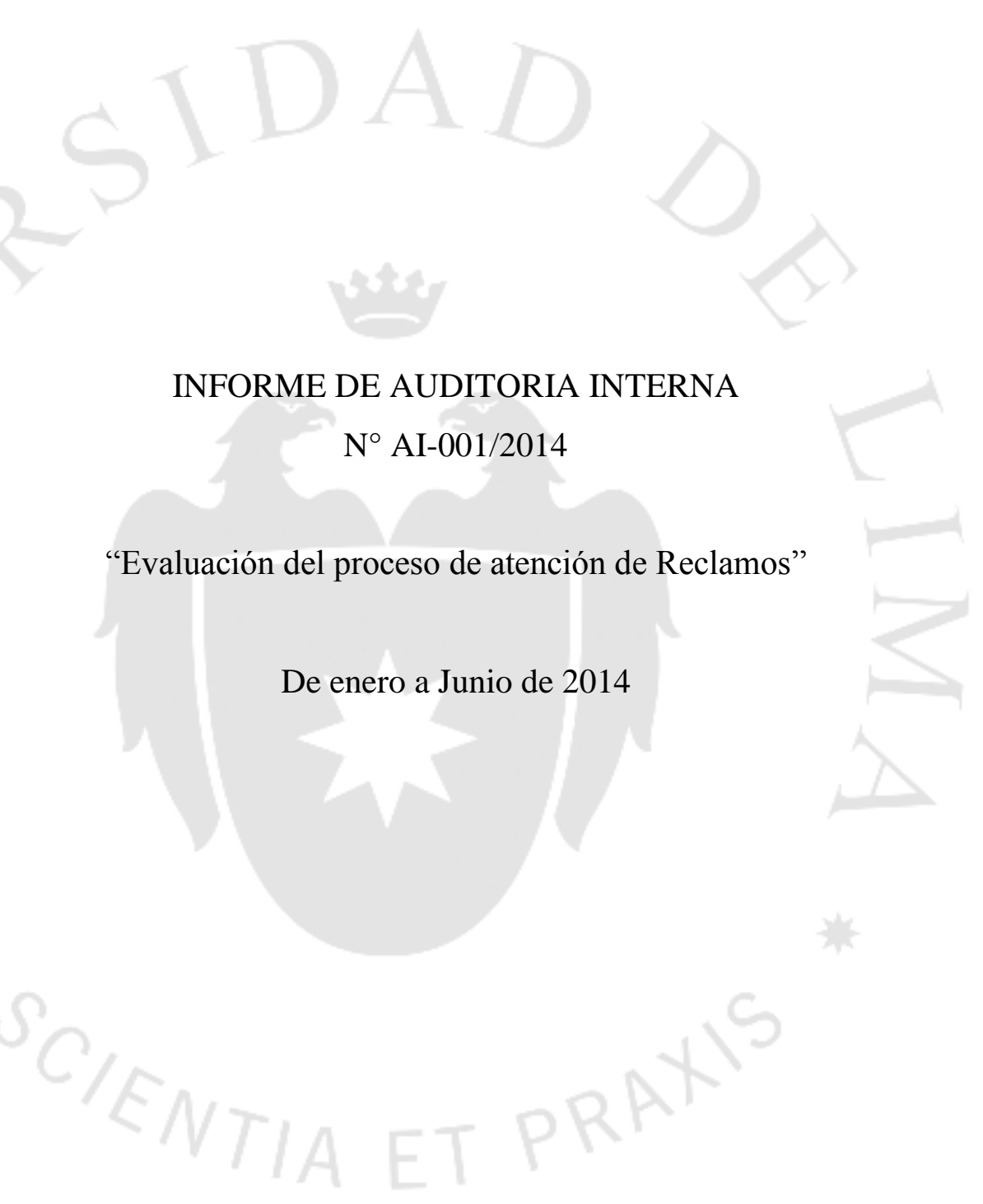




\section{Contenido:}

\section{Resumen Ejecutivo}

Sección A - Detalle de observaciones

Sección B - Evaluación de la Matriz de Riesgo de Negocio (MRN)

Sección C - Requerimientos regulatorios

Sección D - Información complementaria del negocio

Sección E-Definiciones 
Código de la auditoría: AI 001

Jurisdicción: Perú

Unidad de Negocio: Grupo Global de Banca Consumo

Dueño del Proceso: Gerente 1

Fecha del Reporte: Julio 18, 2014.

\begin{tabular}{|c|c|c|c|}
\hline \multicolumn{4}{|c|}{ CALIFICACION DEL PROCESO } \\
\hline & Anterior & Actual & \\
\hline $\begin{array}{l}\text { - Proceso } \\
\text { Evaluado }\end{array}$ & $\begin{array}{c}\text { SUFICIENTE } \\
\text { ASEGURAMIENTO }\end{array}$ & $\begin{array}{l}\text { OPORTUNIDAD } \\
\text { DE MEJORA }\end{array}$ & $\begin{array}{l}\text { Si bien la observación no representa } \\
\text { un riesgo crítico ya que se subsanará } \\
\text { inmediatamente, sin embargo la } \\
\text { gerencia debe estar atenta a tener una } \\
\text { mejora en la gestión de riesgos del } \\
\text { proceso de atención de reclamos de } \\
\text { clientes, principalmente en los } \\
\text { tiempos de respuesta. } \\
\text { Por otra parte, deben adoptarse las } \\
\text { acciones correctivas necesarias para } \\
\text { implementar los aspectos } \\
\text { observados, relacionados } \\
\text { principalmente con el fortalecimiento } \\
\text { del control interno y mejora de } \\
\text { procesos informáticos en la gestión } \\
\text { de los reclamos de clientes. }\end{array}$ \\
\hline \multicolumn{4}{|c|}{ OBSERVACIONES Y NIVEL DE IMPACTO } \\
\hline Nivel 1 & Nivel 2 & Nivel 3 & Nivel 4 \\
\hline $\mathbf{0}$ & $\mathbf{0}$ & $\mathbf{0}$ & 1 \\
\hline
\end{tabular}




\section{Contexto:}

Banco del Perú S.A. es una entidad legal que se desenvuelve como una institución financiera en el país, ofrece productos y servicios a personas y empresas. La superintendencia de Banca, Seguros y AFP (SBS) regula la industria de banca en el Perú.

Los requerimientos regulatorios se establecieron para administrar el servicio de atención de reclamos mediante la circular SBS $\mathrm{N}^{\circ}$ 146-2009, vigente desde el 30 de diciembre del 2009. Esta norma define los lineamientos relacionados a la administración de reclamos y a su vez la responsabilidad del área de auditoría interna de revisar el proceso de atención de reclamos.

\section{Alcance:}

La revisión efectuada al 30.06.2014, fue programada en el Plan Anual de Trabajo en cumplimiento a las normas de la SBS. Se establecieron como objetivos generales de la auditoria: Evaluar el diseño y eficacia operativa de los controles, ayudar en el fortalecimiento de la gestión de riesgos, mejorar los procesos revisados y evitar incumplimientos de normas.

Nuestro alcance incluyó la revisión selectiva (muestras aleatorias) de los procesos revisados; determinándose los siguientes objetivos específicos:

- Verificar el cumplimiento de las normas de la SBS y las políticas, normas y procedimientos de la compañía que rigen la atención de usuarios por reclamos presentados a la empresa.

- $\quad$ Evaluar el sistema de gestión integral de riesgos, a fin de establecer si los procesos de atención de reclamos de clientes (asegurados y beneficiarios) son apropiados, están bien diseñados y están funcionando de acuerdo a lo esperado, en relación a:

- $\quad$ Análisis de Reporte de Reclamos de Clientes.

- $\quad$ Revisión aleatoria de expedientes de clientes con reclamos.

- $\quad$ Comparación de datos incluidos en la data de Reclamos de Clientes con el físico.

- $\quad$ Análisis y comprobación de plazos de atención de reclamos de clientes.

- $\quad$ Revisión de procedimientos internos de reclamos de clientes.

- Revisión del registro de casos de reclamos que involucran riesgos legales presentados a la SBS e Indecopi.

- $\quad$ Indicadores de Gestión de atención de reclamos de clientes.

- $\quad$ Evaluar la calidad de la información que se presenta a la SBS, particularmente la relacionada a los Anexos Trimestrales de Reclamos (1er. y 2do. trimestre del 2014).

- Efectuar seguimiento a la implementación de las recomendaciones de anteriores auditorias (Interna, SBS y Externa).

Las principales técnicas utilizadas estuvieron referidas a: observación, indagación e inspección documentaria. Asimismo, los procedimientos y pruebas de auditoria aplicados en la revisión, estuvieron basados en información proporcionada por el área Comercial (sección: Servicio al Cliente), Operaciones y Técnica (sección: Desarrollo Organizacional), Gerencia Legal y la Unidad de Riesgos.

La metodología aplicada en la auditoria fue efectuada de acuerdo a las Normas y Estándares para la Práctica de la Auditoria Interna, previstas en las Normas Internacionales para el Ejercicio Profesional de la Auditoria Interna así como el Código de Ética emitidos por The Institute of Internal Auditors (IIA). Asimismo, se tomaron en consideración las directrices de auditoria previstas por el Information Systems Audit and Control Association (ISACA), de acuerdo a lo dispuesto en la Resolución SBS N $11699-$ Reglamento de Auditoria Interna, emitida el 28.11.2008.

\section{Bases para la evaluación general:}

El resultado de la auditoría del proceso de atención al usuario ha sido de "Oportunidad de Mejora" ya que se ha detectado una debilidad que tiene un impacto regulatorio y reputacional. Sin embargo, se 
consideran adecuados los controles en la gestión de reclamos (cumplimiento del plazo regulatorio); certificación del staff, y la designación y registro del Oficial responsable de preparar y enviar los reportes regulatorios a la SBS.

Una observación de Nivel 4 ha sido identificada en lo que respecta al cumplimiento de los plazos regulatorios en dónde el control no estaba operando adecuadamente lo cual expone al banco a una posible sanción del regulador. El negocio ha identificado que debe optimizar el proceso a través de su matriz de riesgos, en dónde debe realizar los ajustes necesarios para adecuar los procedimientos y alinearse a la normativa vigente. Ocho controles clave manuales fueron testeados de los cuales siete son preventivos y uno detectivo; Un control no se encuentra operando efectivamente según el detalle de la siguiente sección.

Auditoría interna acordó con el dueño del proceso un plan de acción el cual estará sujeto, luego de su implementación, a procedimientos de seguimiento y validación de observaciones Así mismo, en la opinión de auditoría interna se consideró que el área de atención de reclamos cuente con los recursos necesarios para desarrollar un apropiado nivel de control y demostrar una remediación oportuna de la situación identificada.

No se consideró una revisión de los registros contables debido a que no forman parte del proceso auditado ni de la regulación local.

\section{Resumen de Resultados de la evaluación:}

La siguiente tabla registra el número de observaciones alineadas a riesgos identificados por el negocio.

\begin{tabular}{|c|c|c|c|c|}
\hline Riesgos identificados en la auditoría & $\mathrm{R} / \mathrm{A} / \mathrm{G}$ & $\begin{array}{l}\text { Nivel } \\
\text { de la } \\
\text { obs. }\end{array}$ & $\begin{array}{l}\text { Ref. } \\
\text { Obs. }\end{array}$ & Debilidad en el control \\
\hline $\begin{array}{l}\text { 1. Estructura organizacional } \\
\text { inapropiada. Falta de segregación de } \\
\text { funciones y entrenamiento } \\
\text { inapropiado puede resultar en manejo } \\
\text { inadecuado de las quejas del cliente y } \\
\text { exposición del banco a sanciones del } \\
\text { regulador. }\end{array}$ & & - & - & - \\
\hline $\begin{array}{l}\text { 2. Difusión inapropiada de la } \\
\text { administración de quejas y procesos } \\
\text { de presentación limitan el nivel de } \\
\text { información disponible para los } \\
\text { clientes y expone al banco a } \\
\text { sanciones del regulador. }\end{array}$ & - & - & - & - \\
\hline $\begin{array}{l}\text { 3. Procesos inapropiados para } \\
\text { registrar las quejas de clientes expone } \\
\text { al banco a sanciones del regulador. }\end{array}$ & - & - & - & - \\
\hline $\begin{array}{l}\text { 4. Administración inapropiada y } \\
\text { tardía de quejas de clientes expone al } \\
\text { banco a sanciones del regulador. }\end{array}$ & A & & 1 & $\begin{array}{l}\text { Problemas identificados en la } \\
\text { macro Excel que detonaba el } \\
\text { envío de cartas de extensión } \\
\text { debido a que no se estaban } \\
\text { capturando todos los casos. }\end{array}$ \\
\hline $\begin{array}{l}\text { 5. Inapropiada administración de los } \\
\text { archivos de quejas de los clientes } \\
\text { expone al banco a sanciones del } \\
\text { regulador. }\end{array}$ & - & - & - & - \\
\hline $\begin{array}{l}\text { 6. Administración inapropiada y } \\
\text { atrasada de los reportes de quejas } \\
\text { trimestrales regulatorios expone al } \\
\text { banco a sanciones del regulador. }\end{array}$ & - & - & - & - \\
\hline
\end{tabular}




\section{Leyenda:}

G

Suficiente aseguramiento respecto a la efectividad del ambiente de control para mitigar el riesgo identificado.

A Mediando aseguramiento respecto a la efectividad del ambiente de control para mitigar el riesgo identificado.

R

Insuficiente aseguramiento respecto a la efectividad del ambiente de control para mitigar el riesgo identificado. 


\begin{tabular}{|c|c|c|c|}
\hline $\begin{array}{l}\text { Ref. } \\
\text { obs. }\end{array}$ & Nivel & Observación y su impacto & $\begin{array}{c}\text { Plan de acción acordado y fecha de } \\
\text { cumplimiento }\end{array}$ \\
\hline 1 & 4 & 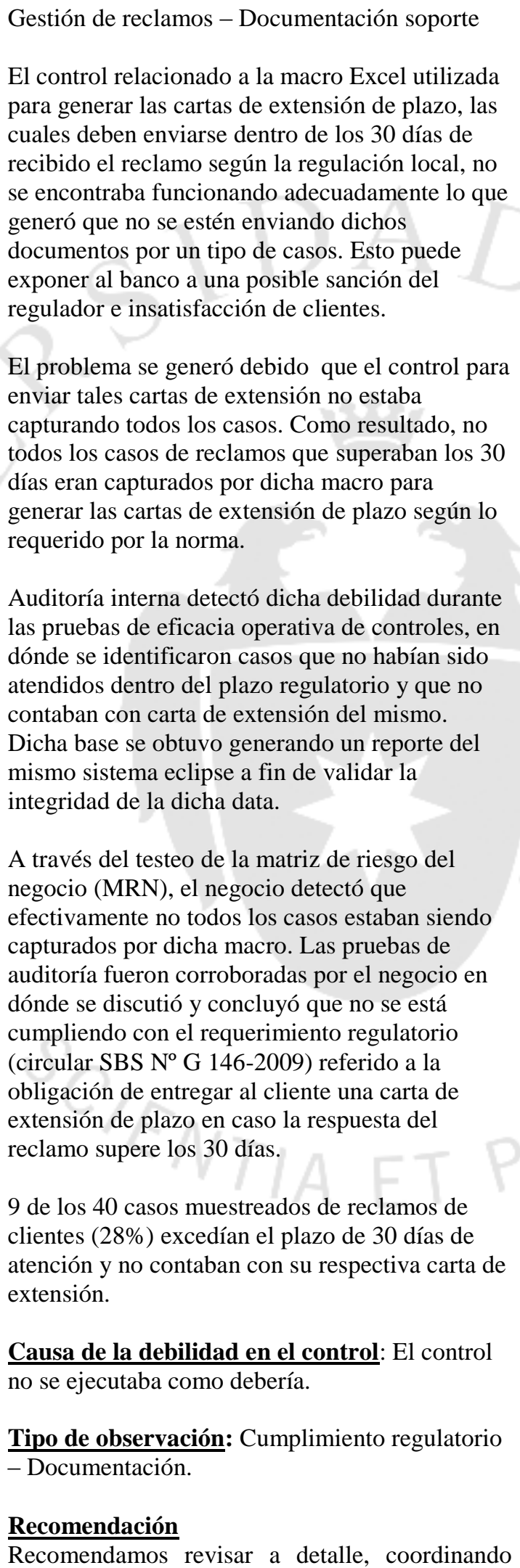 & $\begin{array}{l}\text { Plan de acción: } \\
\text { 1.1 La macro utilizada para } \\
\text { monitorear el anticuamiento de } \\
\text { reclamos será revisada para asegurar } \\
\text { que todos los tipos de reclamos se } \\
\text { capturen. Pendiente la validación de } \\
\text { auditoría interna. } \\
\text { Responsable: Supervisor } 1 \\
\text { Fecha de cumplimiento: } 31.12 .2014 \\
\qquad \text { Se solicitará el apoyo del } \\
\text { 1.2 } \\
\text { equipo regional de desarrollo para } \\
\text { que validen y realicen pruebas en la } \\
\text { macro de acuerdo a las políticas } \\
\text { regionales del uso de aplicativos. } \\
\text { Responsable: Supervisor } 1 \\
\text { Fecha de cumplimiento: } 31.12 .2014 \\
\text { Dueño del proceso: Gerente } 1 \\
\text { Fecha de la observación: } \\
\text { 18.07.2014 } \\
\text { Fecha de validación de } \\
\text { observación: } 15.01 .2015 \text {. }\end{array}$ \\
\hline
\end{tabular}




$\left|\begin{array}{l|l|}\hline \text { con el equipo global de desarrollo de TI, la } \\ \text { macros que filtra yenera las cartas de extensión } \\ \text { de plazo. Así mismo es necesario realizar una } \\ \text { validación preventiva de los casos filtrados en } \\ \text { este aplicativo mediante la conciliación de las } \\ \text { cantidades de reclamos registrados versus los } \\ \text { filtrados por la macros a fin de obtener suficiente } \\ \text { seguridad que todas las cartas que se tiene } \\ \text { conocimiento superarán el plazo regulatorio serán } \\ \text { enviadas a los clientes dentro de dicho tiempo. } \\ \text { Situación actual de la observación: Pendiente }\end{array}\right|$

\section{SECCION B: EVALUACIÓN DE LOS RIESGOS GESTIONADOS POR LA} GERENCIA

\section{Enfoque de auditoría en las Matrices de Riesgo de Negocio (MRN):}

La siguiente tabla registra el número de observaciones alineadas a riesgos identificados por el negocio.

\begin{tabular}{|l|c|c|c|c|c|}
\cline { 2 - 6 } \multicolumn{1}{c|}{} & Nivel 1 & Nivel 2 & Nivel 3 & Nivel 4 & Nivel 5 \\
\hline $\begin{array}{l}\text { Identificado en } \\
\text { MRN }\end{array}$ & - & - & - & 1 & - \\
\hline $\begin{array}{l}\text { No identificado en } \\
\text { MRN }\end{array}$ & - & - & - & - & - \\
\hline $\begin{array}{l}\text { No aplicable a } \\
\text { MRN }\end{array}$ & - & - & - & - & - \\
\hline Total observaciones & - & - & - & - & - \\
\hline
\end{tabular}




\begin{tabular}{|c|c|c|c|c|c|}
\hline \multicolumn{6}{|c|}{ SECCIÓN C: REGULACIÓN LOCAL } \\
\hline Entidad & Descripción de la Regulación & $\begin{array}{c}\text { ¿El control } \\
\text { permite } \\
\text { cumplir con } \\
\text { la } \\
\text { regulación? }\end{array}$ & $\begin{array}{c}\text { ¿Se } \\
\text { identificó } \\
\text { alguna } \\
\text { brecha con } \\
\quad \text { la } \\
\text { regulación? }\end{array}$ & $\begin{array}{l}\text { Ref. } \\
\text { Obs. }\end{array}$ & $\begin{array}{c}\text { Riesgo } \\
\text { Reputacional }\end{array}$ \\
\hline SBS & $\begin{array}{l}\text { Esta regulación establece los } \\
\text { procedimientos relacionados al } \\
\text { registro, monitoreo y resolución } \\
\text { de los reclamos de clientes y la } \\
\text { entrega de la respuesta. Las } \\
\text { entidades financieras deben } \\
\text { asegurarse de cumplir con el } \\
\text { plazo regulatorio de } 30 \text { días } \\
\text { después de presentado el } \\
\text { reclamo. } \\
\text { El plazo puede extenderse } \\
\text { únicamente mediante una } \\
\text { justificación razonable y debe } \\
\text { realizarse dentro del plazo } \\
\text { regulatorio indicando los } \\
\text { motivos de la demora en la } \\
\text { respuesta. } \\
\text { La regulación establece el } \\
\text { tiempo en el cual los casos deben } \\
\text { ser atendidos. A su vez, requiere } \\
\text { de un oficial responsable del área } \\
\text { de atención de reclamos. Así } \\
\text { mismo, dicho oficial debe } \\
\text { presentar trimestralmente } \\
\text { información estadística de } \\
\text { reclamos a la gerencia y el } \\
\text { regulador. Adicionalmente estas } \\
\text { estadísticas deben publicarse en } \\
\text { su página WEB. } \\
\text { Finalmente, el Oficial de } \\
\text { Atención al usuario debe } \\
\text { presentar un informe anual al } \\
\text { directorio. }\end{array}$ & $\mathrm{Si}$ & $\mathrm{Si}$ & 1 & -4 \\
\hline
\end{tabular}




\begin{tabular}{|c|c|}
\hline Perfil del negocio & $\begin{array}{l}\text { Banco del Perú S.A. es una entidad que opera legalmente como una } \\
\text { institución financiera en el país, la cual ofrece productos y servicios a } \\
\text { personas y empresas. Las operaciones realizadas por el banco son } \\
\text { mayormente realizadas como intermediación entre múltiples bancos, tales } \\
\text { actividades se encuentran reguladas por la superintendencia de banca, seguros } \\
\text { y AFP. }\end{array}$ \\
\hline auditoría & $\begin{array}{l}\text { El alcance de la auditoría se enfoca en el diseño y eficacia operativa de los } \\
\text { controles para asegurar que el banco cumple con la regulación según la } \\
\text { circular SBS } \mathrm{N}^{\circ} \mathrm{G} \text { 146-2009 relacionada a la atención de reclamos de } \\
\text { clientes. } \\
\text { Basados en la regulación local y la evaluación realizada durante la etapa de } \\
\text { planeamiento, el alcance de la auditoría incluye lo siguiente: } \\
\text { - } \quad \text { Establecimiento de políticas y procedimientos relacionados a la } \\
\text { norma de atención de reclamos. } \\
\text { - Mecanismos de comunicación y difusión de información relacionada } \\
\text { a la administración de reclamos. } \\
\text { - } \quad \text { Gestión y respuesta de reclamos. } \\
\text { - }\end{array}$ \\
\hline $\begin{array}{l}\text { Enfo } \\
\text { audi }\end{array}$ & $\begin{array}{l}\text { El enfoque de auditoría incluyó la obtención de un entendimiento de las } \\
\text { normas aplicables y el proceso del área involucrada. Ello se pudo conseguir a } \\
\text { través de la evaluación de: Políticas y procedimientos, documentación, } \\
\text { discusión con la gerencia y la eficacia de controles clave y procesos. } \\
\text { Finalmente, los procedimientos de testeo, se desarrollaron y utilizaron para } \\
\text { determinar la eficacia operativa de los controles mediante inspección, } \\
\text { indagación y revisión de documentos. Se llevaron a cabo reuniones } \\
\text { programadas con el negocio para informarles acerca del proceso de auditoría } \\
\text { y para confirmar con precisión las situaciones reportadas como observaciones } \\
\text { conforme se iban identificando. }\end{array}$ \\
\hline $\begin{array}{l}\text { Equipo de auditoría } \\
\text { responsable de la } \\
\text { evaluación del proceso }\end{array}$ & $\begin{array}{l}\text { Gerente de auditoría: Gerente } 1 \\
\text { Supervisor de auditoría: Supervisor } 1 \\
\text { Cosourcing de auditoría: Alonso Rivero Zanatta }\end{array}$ \\
\hline
\end{tabular}


SECCION E: DEFINICIONES

\section{Efectividad de la MRN (Matriz de Riesgo de Negocio)}

Auditoría interna efectúa pruebas de testeo de los controles clave identificados por el negocio y otros controles no contemplados que deberían existir para determinar la efectividad del proceso de identificación de riesgos por parte de la gerencia. Al final de cada auditoría, AI reporta lo siguiente:

1. Controles clave que operan eficazmente - El número de controles clave que auditoría interna ha probado que están diseñados y operan eficazmente.

2. Controles clave identificados en el alcance de la MRN - El número de controles clave que la gerencia ha considerado en su matriz MRN versus el número de controles que auditoría interna ha testeado y considera que deberían incluirse en dicha matriz.

3. Los controles clave identificados iguala a los controles clave verificados por auditoría interna Sean efectivos o no

\section{Situaciones identificadas por el negocio como oportunidad de mejora (SIGPM)}

Son los eventos dentro del proceso que han sido identificados por la misma gerencia como oportunidad de mejora. Para poder calificar como SIGPM y no formar parte de las observaciones del reporte de auditoría debe cumplir con los siguientes criterios:

- Plan de acción: Refiere cuando el negocio ha documentado formalmente planes de acción correctivos (incluidas acciones definidas y cronograma de actividades de levantamiento) para resolver la situación y mitigar el riesgo.

- $\quad$ Recursos: Refiere cuando se ha aprobado la destinación de recursos para el levantamiento de la situación.

- Fondos: Alineado a los recursos, debe contar con un presupuesto asignado ya que podría implicar cambios en procedimientos o sistemas.

- $\quad$ Progreso: El plan de acción correctivo elaborado debe sustentarse con evidencia tangible del progreso de ejecución de actividades de levantamiento de situaciones. 


\section{ESCALA DE CALIFICACION DEL PROCESO}

Calificación del proceso

\begin{tabular}{|c|c|c|c|}
\hline $\begin{array}{c}\text { Suficiente } \\
\text { Aseguramiento }\end{array}$ & $\begin{array}{c}\text { Oportunidad de } \\
\text { Mejora }\end{array}$ & $\begin{array}{l}\text { Aseguramiento } \\
\text { Limitado }\end{array}$ & $\begin{array}{c}\text { Insuficiente } \\
\text { Aseguramiento }\end{array}$ \\
\hline $\begin{array}{l}\text { Los resultados de la } \\
\text { auditoría indican que } \\
\text { existe suficiente } \\
\text { aseguramiento en el } \\
\text { diseño y efectividad } \\
\text { operativa de los } \\
\text { controles para mitigar o } \\
\text { administrar los riesgos a } \\
\text { los cuales el proceso } \\
\text { auditado se encuentra } \\
\text { expuesto. }\end{array}$ & $\begin{array}{l}\text { Los resultados de la } \\
\text { auditoría indican que a } \\
\text { pesar que se cuenta con } \\
\text { suficiente } \\
\text { aseguramiento en el } \\
\text { diseño y efectividad } \\
\text { operativa de los } \\
\text { controles para mitigar o } \\
\text { administrar los riesgos a } \\
\text { los cuales el proceso } \\
\text { auditado se encuentra } \\
\text { expuesto, debe prestarse } \\
\text { atención en adecuar } \\
\text { cierto control(es) de } \\
\text { cierta(s) área(s). }\end{array}$ & $\begin{array}{l}\text { Los resultados de la } \\
\text { auditoría indican existe } \\
\text { un nivel de } \\
\text { aseguramiento limitado } \\
\text { en el diseño y } \\
\text { efectividad operativa de } \\
\text { los controles para } \\
\text { mitigar o administrar los } \\
\text { riesgos a los cuales el } \\
\text { proceso auditado se } \\
\text { encuentra expuesto. La } \\
\text { existencia de } \\
\text { observaciones } \\
\text { reiterativas también se } \\
\text { considera en esta } \\
\text { calificación. }\end{array}$ & $\begin{array}{l}\text { Los resultados de la } \\
\text { auditoría indican existe } \\
\text { un nivel de } \\
\text { aseguramiento } \\
\text { insuficiente en el } \\
\text { diseño y efectividad } \\
\text { operativa de los } \\
\text { controles para mitigar } \\
\text { o administrar los } \\
\text { riesgos a los cuales el } \\
\text { proceso auditado se } \\
\text { encuentra expuesto. }\end{array}$ \\
\hline
\end{tabular}

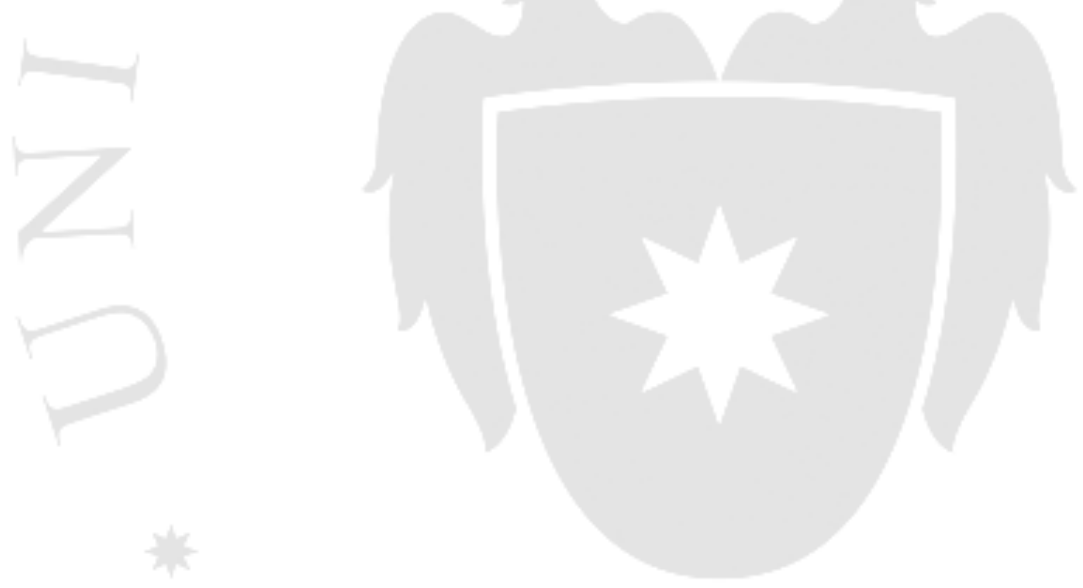




\begin{tabular}{|c|c|c|c|c|}
\hline \multicolumn{5}{|c|}{ NIVELES DE CLASIFICA CIÓN DE OBSERVACIONES } \\
\hline Ni & Nivel General & Riesgo Regulatorio & $\begin{array}{c}\text { Desviación de } \\
\text { políticas }\end{array}$ & $\begin{array}{c}\text { Riesgo } \\
\text { Reputacional }\end{array}$ \\
\hline $\begin{array}{r}\text { Niv } \\
1\end{array}$ & $\begin{array}{l}\text { Debilidad en el control a } \\
\text { nivel global puede } \\
\text { impactar las estrategias u } \\
\text { objetivos del Banco. } \\
\text { Acción inmediata de la } \\
\text { Gerencia es requerida } \\
\text { para asegurar que los } \\
\text { riesgos son mitigados y } \\
\text { la remediación es } \\
\text { efectiva. }\end{array}$ & $\begin{array}{l}\text { Debilidad en el control } \\
\text { que puede resultar en } \\
\text { acciones del regulador } \\
\text { que generarían un } \\
\text { efecto adverso en la } \\
\text { capacidad del Banco de } \\
\text { continuar con sus } \\
\text { operaciones en un país } \\
\text { o región y el riesgo de } \\
\text { sanción o multa. } \\
\text { La debilidad en el } \\
\text { control puede deberse a } \\
\text { incumplimientos } \\
\text { sustanciales o } \\
\text { reiterativos de la } \\
\text { regulación. }\end{array}$ & $\begin{array}{l}\text { Debilidad en el } \\
\text { control que se } \\
\text { desarrolla debido al } \\
\text { incumplimiento de } \\
\text { políticas } \\
\text { corporativas. La } \\
\text { política puede no } \\
\text { existir, estar } \\
\text { inapropiadamente } \\
\text { diseñada o no operar } \\
\text { eficazmente. }\end{array}$ & 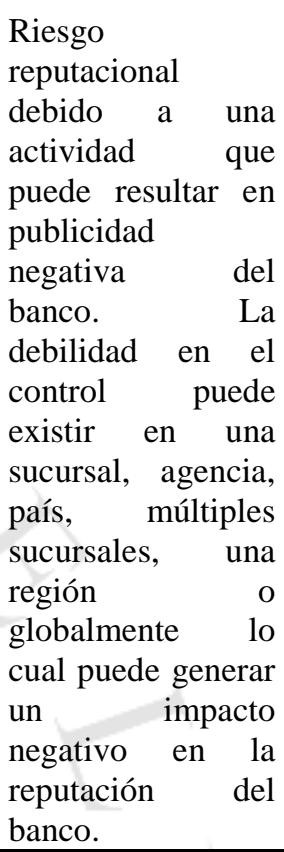 \\
\hline $\begin{array}{c}\text { Nivel } \\
2\end{array}$ & $\begin{array}{l}\text { Debilidad respecto a } \\
\text { deficiencia en los } \\
\text { controles o debilidad que } \\
\text { afecta al negocio, región } \\
\text { o línea de producto, } \\
\text { canales de entrega o } \\
\text { herramientas de servicio } \\
\text { compartidas. Acción } \\
\text { inmediata de la Gerencia } \\
\text { es requerida para } \\
\text { asegurar que los riesgos } \\
\text { son mitigados y la } \\
\text { remediación es efectiva. }\end{array}$ & $\begin{array}{l}\text { Debilidad en el control } \\
\text { que puede resultar en } \\
\text { acciones del regulador } \\
\text { que generarían un } \\
\text { efecto adverso en la } \\
\text { capacidad del Banco de } \\
\text { continuar con sus } \\
\text { operaciones en un país } \\
\text { o región y el riesgo de } \\
\text { sanción o multa. }\end{array}$ & $\begin{array}{l}\text { Regional: Falta de } \\
\text { políticas, } \\
\text { inapropiado diseño } \\
\text { de las políticas o } \\
\text { falla en la eficacia } \\
\text { operativa de las } \\
\text { mismas que } \\
\text { generaría fallas en } \\
\text { los controles. }\end{array}$ & $\begin{array}{l}\text { Riesgo } \\
\text { reputacional } \\
\text { debido a una } \\
\text { actividad } \\
\text { puede resultar en } \\
\text { publicidad } \\
\text { negativa } \\
\text { banco. } \\
\text { debilidad en el } \\
\text { control puede } \\
\text { existir a nivel } \\
\text { regional lo cual } \\
\text { puede generar un } \\
\text { impacto negativo } \\
\text { en la reputación } \\
\text { del banco. }\end{array}$ \\
\hline $\begin{array}{c}\text { Nivel } \\
3\end{array}$ & $\begin{array}{l}\text { Debilidad del control a } \\
\text { nivel funcional o } \\
\text { producto } \\
\text { inconformidad con las } \\
\text { políticas del banco. } \\
\text { Actividades de gobierno } \\
\text { fallidas o múltiples } \\
\text { desviaciones en los } \\
\text { procedimientos } \\
\text { establecidos. }\end{array}$ & $\begin{array}{l}\text { Debilidad en el control } \\
\text { que puede resultar en } \\
\text { acciones del regulador } \\
\text { que impactarían en el } \\
\text { negocio de una región } \\
\text { o red de agencias. }\end{array}$ & $\begin{array}{l}\text { Políticas } \\
\text { procedimientos } \\
\text { funcionales } \\
\text { legales, falta de } \\
\text { políticas, } \\
\text { inapropiado diseño } \\
\text { de las políticas, o } \\
\text { fallas en la eficacia } \\
\text { operativa de una } \\
\text { política puede } \\
\text { generar fallas en los } \\
\text { controles. }\end{array}$ & $\begin{array}{l}\text { Riesgo } \\
\text { reputacional } \\
\text { debido a una } \\
\text { actividad } \\
\text { puede resultar } \\
\text { publicidad } \\
\text { negativa } \\
\text { banco. } \\
\text { debilidad en } \\
\text { control el } \\
\text { existir a nivel país } \\
\text { lo cual puede } \\
\text { generar } \\
\text { impacto negativo }\end{array}$ \\
\hline
\end{tabular}




\begin{tabular}{|c|c|c|c|c|}
\hline & & & & $\begin{array}{l}\text { en la reputación } \\
\text { del banco. }\end{array}$ \\
\hline $\begin{array}{c}\text { Nivel } \\
4\end{array}$ & $\begin{array}{l}\text { Debilidad del control } \\
\text { respecto a desviación del } \\
\text { marco regulatorio } \\
\text { requiereracción } \\
\text { inmediata de la gerencia } \\
\text { y planes de acción } \\
\text { correctivos para alinearse } \\
\text { a la normativa vigente. }\end{array}$ & $\begin{array}{l}\text { Debilidad en el control } \\
\text { que puede resultar en } \\
\text { acciones de regulador } \\
\text { que afectarían a la } \\
\text { entidad o jurisdicción } \\
\text { local y puede } \\
\text { relacionarse a violación } \\
\text { de políticas o } \\
\text { procedimientos. }\end{array}$ & $\begin{array}{l}\text { Políticas } \\
\text { procedimientos del } \\
\text { negocio o de } \\
\text { productos, } \\
\text { inapropiado diseño } \\
\text { de las políticas, o } \\
\text { fallas en la eficacia } \\
\text { operativa de una } \\
\text { política puede } \\
\text { generar fallas en los } \\
\text { controles. }\end{array}$ & $\begin{array}{l}\text { Riesgo } \\
\text { reputacional } \\
\text { debido a una } \\
\text { actividad } \\
\text { puede resultar en } \\
\text { publicidad } \\
\text { negativa } \\
\text { banco. del } \\
\text { debilidad en el } \\
\text { control puede } \\
\text { existir a entidad lo } \\
\text { cual puede generar } \\
\text { un impacto } \\
\text { negativo en la } \\
\text { reputación r del } \\
\text { banco. }\end{array}$ \\
\hline $\begin{array}{c}\text { Nivel } \\
5\end{array}$ & $\begin{array}{l}\text { Debilidad del control } \\
\text { requiere de atención por } \\
\text { parte de la Gerencia y } \\
\text { medidas correctivas a } \\
\text { nivel proceso o agencias. }\end{array}$ & $\begin{array}{l}\text { Debilidad en el control } \\
\text { que puede resultar en } \\
\text { sanciones } \\
\text { comentarios } \\
\text { regulador a } \\
\text { sucursales. }\end{array}$ & $\begin{array}{l}\text { Políticas y } \\
\text { procedimientos de } \\
\text { agencias, } \\
\text { inapropiado diseño } \\
\text { de las políticas, o } \\
\text { fallas en la eficacia } \\
\text { operativa de una } \\
\text { política puede } \\
\text { generar fallas en los } \\
\text { controles. }\end{array}$ & 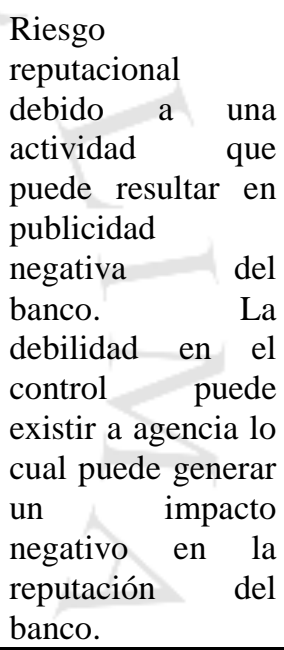 \\
\hline
\end{tabular}


ANEXO N 7 - Documentación

\begin{tabular}{|c|c|c|c|c|c|c|}
\hline $\mathbf{N}^{\circ}$ & Documento & Código & Estatus & $\begin{array}{l}\text { Hecho } \\
\text { por }\end{array}$ & $\begin{array}{l}\text { Revisado } \\
\text { por }\end{array}$ & Fecha \\
\hline \multicolumn{7}{|c|}{ Plan anual de auditoría basada en riesgos } \\
\hline 1 & Planificación administrativa & ABR 001 & Completado & G1 & D1 & \multirow[t]{2}{*}{$15 / 12 / 2013$} \\
\hline 2 & Programación de fechas & ABR 002 & Completado & G1 & D1 & \\
\hline \multicolumn{7}{|c|}{ Pre auditoría } \\
\hline 2 & $\begin{array}{l}\text { Manuales de políticas y } \\
\text { procedimientos }\end{array}$ & PA-001 & Completado & ARZ & G1 & $16 / 06 / 2014$ \\
\hline 3 & $\begin{array}{l}\text { Memo Requerimiento de } \\
\text { información }\end{array}$ & PA-002 & Completado & ARZ & G1 & $16 / 06 / 2014$ \\
\hline 4 & $\begin{array}{l}\text { Presentación de la reunión } \\
\text { de inicio de la auditoría }\end{array}$ & PA-003 & Completado & ARZ & & $16 / 06 / 2014$ \\
\hline \multirow[t]{2}{*}{5} & Matriz de Riesgos del & $n$ & 24 & & & \multirow[b]{2}{*}{$16 / 06 / 2014$} \\
\hline & Negocio (MRN) & PA-004 & Completado & ARZ & G1 & \\
\hline \multicolumn{7}{|c|}{ Planeación } \\
\hline 7 & Flujograma del proceso & PL-001 & Completado & ARZ & G1 & $14 / 07 / 2014$ \\
\hline 8 & Matriz de riesgos y controles & PL-002 & Completado & ARZ & G1 & $14 / 07 / 2014$ \\
\hline & Marco Regulatorio & PL-003 & Completado & ARZ & G1 & $14 / 07 / 2014$ \\
\hline \multicolumn{7}{|c|}{$\begin{array}{l}\text { Prueba de diseños de } \\
\text { controles }\end{array}$} \\
\hline & PDC 1.1 & PL-004 & Completado & ARZ & G1 & $01 / 08 / 2014$ \\
\hline & PDC 1.2 & PL-005 & Completado & ARZ & G1 & $01 / 08 / 2014$ \\
\hline & PDC 1.3 & PL-006 & Completado & ARZ & G1 & $01 / 08 / 2014$ \\
\hline & PDC 2.1 & PL-007 & Completado & ARZ & G1 & $01 / 08 / 2014$ \\
\hline \multicolumn{2}{|r|}{ PDC 3.1} & PL-008 & Completado & ARZ & G1 & $01 / 08 / 2014$ \\
\hline \multirow{2}{*}{\multicolumn{2}{|c|}{$\begin{array}{l}\text { PDC } 4.1 \\
\text { PDC } 5.1\end{array}$}} & PL-009 & Completado & ARZ & G1 & \multirow{2}{*}{$\begin{array}{l}01 / 08 / 2014 \\
01 / 08 / 2014\end{array}$} \\
\hline & & PL-010 & Completado & ARZ & G1 & \\
\hline & PDC 6.1 & PL-011 & Completado & ARZ & G1 & $01 / 08 / 2014$ \\
\hline \multicolumn{7}{|c|}{$\begin{array}{l}\text { Trabajo de Campo } \\
11 \quad \begin{array}{l}\text { Prueba de eficacia de } \\
\text { controles }\end{array}\end{array}$} \\
\hline & PEC 2.1 & TC-001 & Completado & ARZ & G1 & $29 / 08 / 2014$ \\
\hline & PEC 3.1 & TC-002 & Completado & ARZ & G1 & $29 / 08 / 2014$ \\
\hline & PEC 6.1 & TC-003 & Completado & ARZ & G1 & $29 / 08 / 2014$ \\
\hline \multicolumn{7}{|c|}{ Reporte de auditoría } \\
\hline 12 & $\begin{array}{l}\text { Informe de auditoría interna } \\
\text { AI } 001 / 2014\end{array}$ & RA-001 & Completado & ARZ & G1 & $18 / 09 / 2014$ \\
\hline & gerencia & RA-002 & Completado & ARZ & G1 & $18 / 09 / 2014$ \\
\hline \multicolumn{2}{|c|}{ Seguimiento } & & Completado & ARZ & G1 & \\
\hline 14 & $\begin{array}{l}\text { Levantamiento de } \\
\text { observaciones }\end{array}$ & SE-001 & Pendiente & & & $15 / 01 / 2015$ \\
\hline
\end{tabular}




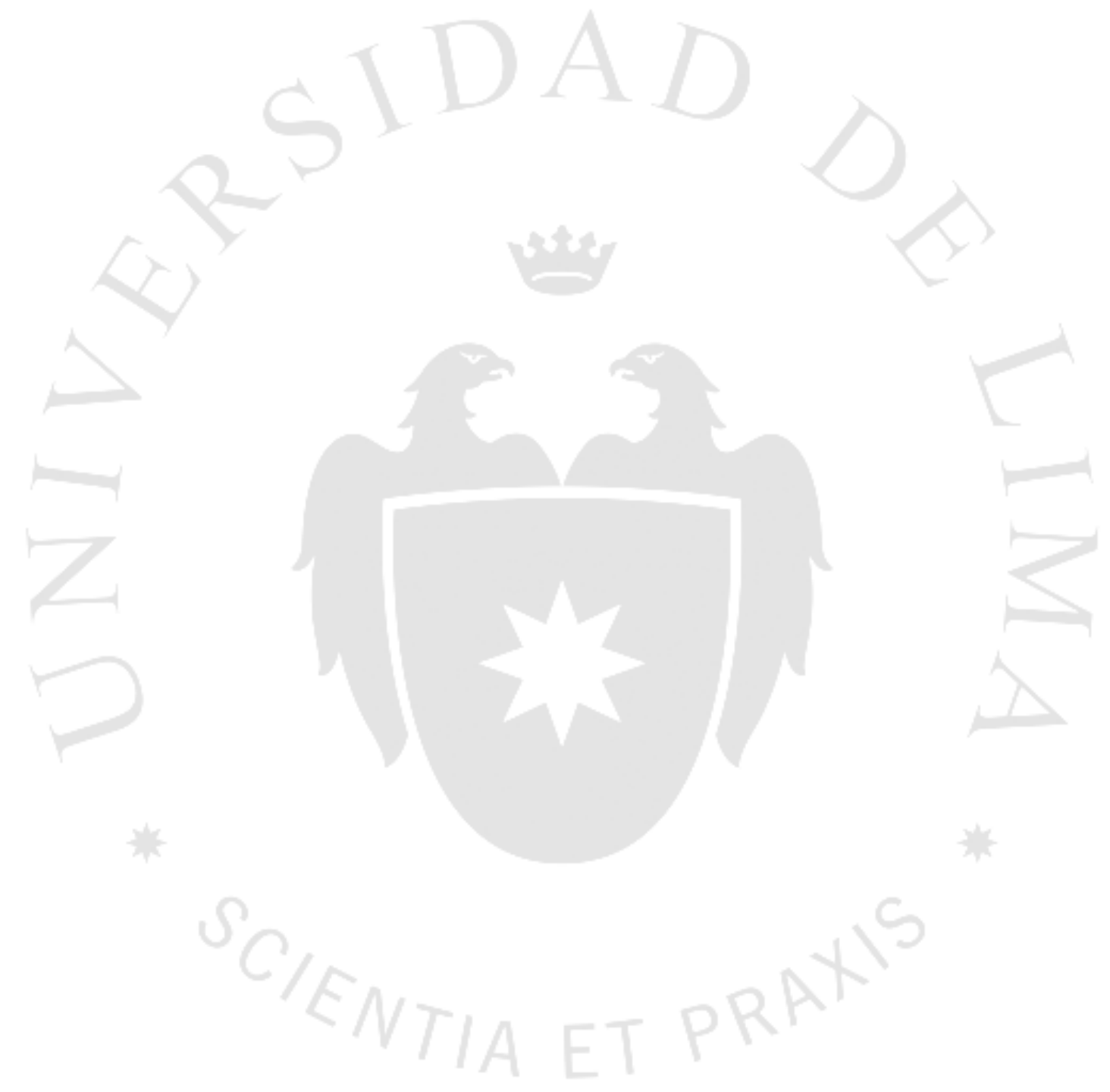

